UNIVERSIDADE DE SÃO PAULO

ESCOLA DE ENGENHARIA DE SÃO CARLOS

DEPARTAMENTO DE HIDRÁULICA E SANEAMENTO

PROGRAMA DE PÓS-GRADUAÇÃO EM HIDRÁULICA E SANEAMENTO

Ana Carolina Franco Ferreira de Andrade

\title{
AVALIAÇÃO DA PRODUÇÃO DE HIDROGÊNIO POR BACTÉRIA \\ FOTOTRÓFICA PÚRPURA NÃO-SULFUROSA EM REATOR EM BATELADA
}

Dissertação apresentada à Escola de Engenharia de São Carlos da Universidade de São Paulo, como parte dos requisitos para obtenção do Título de Mestre em Hidráulica e Saneamento.

Orientadora: Profa. Dra. Maria Bernadete A. Varesche

São Carlos - SP

Junho de 2007 
AUTORIZO A REPRODUÇĀO E DIVULGAÇÃO TOTAL OU PARCIAL DESTE TRABALHO, POR QUALQUER MEIO CONVENCIONAL OU ELETRÔNICO, PARA FINS DE ESTUDO E PESQUISA, DESDE QUE CITADA A FONTE.

Ficha catalográfica preparada pela Seçäo de Tratamento da Informaçăo do Serviço de Biblioteca - EESC/USP

A.553a

Andrade, Ana Carolina Franco Ferreira de

Avaliação da produção de hidrogênio por bactéria fototrófica púrpura năo-sulfurosa em reator em batelada / Ana Carolina Franco Ferreira de Andrade; orientador Maria Bernadete A Varesche. -- São Carlos, 2007.

Dissertaçăo (Mestrado) - Programa de Pós-Graduaçăo e Área de Concentraçăo em Hidráulica e Saneamento -- Escola de Engenharia de São Carlos da Universidade de São Paulo.

1. Saneamento. 2. Produção de hidrogênio. 3. Ácido acético. 4. Bactéria fototrofica púrpura năo-sulfurosa. I. Titulo. 


$$
\text { MPOaneshe Mprovada. }
$$
Prot $t^{2}$. Di ${ }^{3}$. MARIA BERNADETE AMANCIO VARESCHE SILVA (Orientadora) (Escola de Engenharia de Săo Carlos/USP)
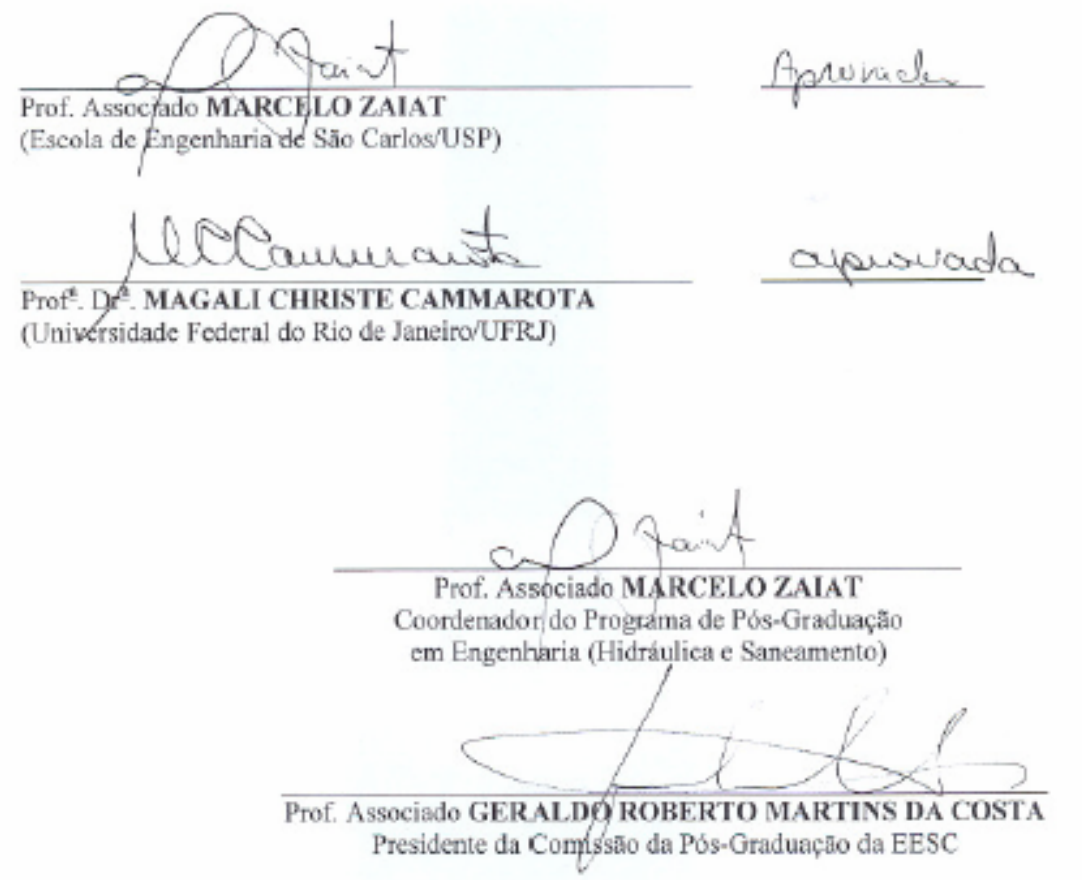
Aos meus pais Aristides e Rita, por todo o apoio e compreensão. 


\section{Agradecimentos}

À Professora Dra. Maria Bernadete A. Varesche pela amizade, apoio, orientação, e por acreditar no meu trabalho.

Às secretárias do Departamento de Hidráulica e Saneamento, Sá e Pavi, pela atenção e ajuda nos assuntos burocráticos.

Aos docentes e funcionários do Departamento de Hidráulica e Saneamento da EESCUSP pela dedicação e orientação que dispensam a seus alunos.

À Beth Moraes e Janja pela paciência, amizade e constante ajuda no laboratório.

Aos amigos do LPB: Alexandre, Arnaldo, Bruna, Clara, Dani, Eloísa, Gunther, Leonardo, Lorena, Lucas, Luiz Ricardo, Márcia, Mércia, Sandra, Tiago e tantos outros que compartilharam trabalho e momentos de descontração no LPB.

À Kátia e Tininha pela amizade, paciência e grande ajuda.

À Érika, Júlia e Noemi pela amizade, companheirismo, ajuda e momentos de descontração.

Aos amigos eternos Carol, Fer, Géssia, Thaís e Lu pelo apoio, amizade, paciência, conselhos e momentos de descontração.

Aos amigos de Cerqueira que mesmo distante sempre me apoiaram.

Ao Murilo pela amizade, apoio, companheirismo e muita paciência.

Aos meus irmãos Daniel e Karen, companheiros de brigas e grandes alegrias.

À minha mãe Rita e ao meu pai Aristides, exemplo a ser seguido.

À CAPES pela bolsa concedida.

A todos que, de alguma forma, contribuíram para a realização deste trabalho. 
“É preciso pensar para acertar, calar para resistir e agir para vencer"

Renato Kebl 


\section{RESUMO}

ANDRADE, A. C. F. F. Avaliação da produção de hidrogênio por bactéria fototrófica púrpura não-sulfurosa em reator em batelada. 2007. Dissertação (Mestrado) - Escola de Engenharia de São Carlos, Universidade de São Paulo, São Paulo, 2007.

As necessidades de energia global são, na sua maioria, dependentes de combustíveis fósseis. Hidrogênio é uma energia limpa alternativa a esses combustíveis. Bactérias fototróficas produzem hidrogênio a partir de compostos orgânicos por meio de processo anaeróbio dependente de luz. Assim, este trabalho visou avaliar o efeito das concentrações iniciais de ácido acético e biomassa, e a influência da intensidade luminosa, na produção de hidrogênio por bactéria fototrófica púrpura não-sulfurosa. Foram utilizados reatores em batelada de $2000 \mathrm{~mL}$, com volume útil de $1000 \mathrm{~mL}$ e headspace de $1000 \mathrm{~mL}$ preenchido com hélio. Nos reatores foi adicionado ácido acético e glutamato de sódio $(0,8 \mathrm{mmol} / \mathrm{L})$ como fontes de carbono e nitrogênio, respectivamente, e cultura de bactéria fototrófica púrpura nãosulfurosa previamente purificada. $\mathrm{O}$ aumento da concentração inicial de ácido acético de $10 \mathrm{mmol} / \mathrm{L}$ para $17 \mathrm{mmol} / \mathrm{L}$ não promoveu mudanças significativas tanto no crescimento celular, quanto, na produção de hidrogênio $\left(8,3 \mathrm{~mL} \mathrm{H}_{2} / \mathrm{g}\right.$ massa seca.h e $8,8 \mathrm{~mL} \mathrm{H}_{2} / \mathrm{g}$ massa seca.h, respectivamente), para intensidade luminosa de 9000 - 10.000 lux. Nessa mesma intensidade luminosa, o aumento da concentração de biomassa inicial de 0,02 g/L para $0,04 \mathrm{~g} / \mathrm{L}$ favoreceu o aumento da produção de hidrogênio de $8,8 \mathrm{~mL} \mathrm{H}_{2} / \mathrm{g}$ massa seca.h para $10,6 \mathrm{~mL} \mathrm{H}_{2} / \mathrm{g}$ massa seca.h, respectivamente. A produção de hidrogênio diminuiu acentuadamente de $10,6 \mathrm{~mL} \mathrm{H}_{2} / \mathrm{g}$ massa seca.h para $1,0 \mathrm{~mL} \mathrm{H}_{2} / \mathrm{g}$ massa seca.h com a diminuição da intensidade luminosa de 9000 - 10.000 lux para 4000 - 5000 lux. Na ausência de luz não ocorreu crescimento e produção de hidrogênio. A cultura manteve-se predominantemente avermelhada e as análises microscópicas mostraram a predominância de bacilos curvos, Gram-negativos, aglomerados em formações de roseta; características típicas de alguns gêneros de bactérias fototróficas púrpuras não-sulfurosas. Todos os ensaios foram realizados à temperatura de $30 \pm 1^{\circ} \mathrm{C}$. A análise da estrutura da comunidade microbiana foi realizada por reação de polimerização em cadeia (PCR) de fragmentos do gene RNAr 16S, seguida de eletroforese em gel de gradiente desnaturante (DGGE), e revelou que não houve variações relevantes na estrutura das populações microbianas em função das diferentes condições de cultivo.

Palavras-chave: produção de hidrogênio, ácido acético, bactéria fototrófica púrpura nãosulfurosa. 


\begin{abstract}
ANDRADE, A. C. F. F. Evaluation of hydrogen production by purple non-sulfur phototrophic in batch reactor. 2007. M.Sc. Dissertation - Escola de Engenharia de São Carlos, Universidade de São Paulo, São Paulo, 2007.
\end{abstract}

The global energy requirements are mostly dependent on fossil fuels. Hydrogen is a clean energy alternative to these fuels. Phototrophic bacteria produce hydrogen from organic compounds by an anaerobic light-dependent electron transfer process. Therefore, this study aimed at to evaluate the effect of the initial concentrations of acetic acid and biomass, and the influence of the light intensity on hydrogen production by purple non-sulfur phototrophic bacteria. The experiments were performed in batch operation, in reactors of $2000 \mathrm{~mL}$, with culture volume of $1000 \mathrm{~mL}$ and headspace of $1000 \mathrm{~mL}$, filled with helium. Acetic acid and sodium glutamate $(0.8 \mathrm{mmol} / \mathrm{L})$ were used as sources of carbon and nitrogen, respectively, and culture of purple non-sulfur phototrophic bacteria previously purifided. The increase of the initial acetic acid concentration from $10 \mathrm{mmol} / \mathrm{L}$ to $17 \mathrm{mmol} / \mathrm{L}$ did not promote significant changes in the cell growth and in the hydrogen production $\left(8.3 \mathrm{~mL} \mathrm{H}_{2} / \mathrm{g}\right.$ dry weight.h and $8.8 \mathrm{~mL} \mathrm{H}_{2} / \mathrm{g}$ dry weight.h, respectively), under a light intensity of $9000-10,000$ lux. In this same light intensity, the increase of the initial biomass concentration from $0.02 \mathrm{~g} / \mathrm{L}$ to $0.04 \mathrm{~g} / \mathrm{L}$ resulted in an increase in the hydrogen production from $8.8 \mathrm{~mL} \mathrm{H}_{2} / \mathrm{g}$ dry weight.h to $10.6 \mathrm{~mL} \mathrm{H}_{2} / \mathrm{g}$ dry weight.h, respectively. The hydrogen production suddenly decreased from $10.6 \mathrm{~mL} \mathrm{H} / \mathrm{g}$ dry weigh.h to $1.0 \mathrm{~mL} \mathrm{H}_{2} / \mathrm{g}$ dry weight.h with the reduction of the light intensity from 9000 - 10,000 lux to 4000 - 5000 lux. Hydrogen production was not observed in absence of light. The culture remained predominantly purple and the microscopic analysis showed the predominance of rod-shaped cells, Gram-negative, accumulated in formation of rosettes; typical characteristics of some types of purple non-sulfur phototrophic bacteria. The analysis of the structure of the microbial community was carried out by reaction of polymerization in chain (PCR) of the RNAr 16S, followed of denaturing gradient gel electrophoresis (DGGE), and reveled that the structure of the microbial populations did not change significantly in function of the different conditions of culture.

Key words: hydrogen production, acetic acid, purple non-sulfur phototrophic bacteria. 


\section{LISTA DE FIGURAS}

Figura 3.1. Esquema geral de produção de hidrogênio por bactérias fototróficas púrpuras não-sulfurosas

Figura 4.1. Fluxograma experimental

Figura 4.2. Reator em batelada $(5000 \mathrm{~mL})$

Figura 4.3. Reator anaeróbio em batelada

Figura 5.1. Microscopia óptica de contraste de fase das seguintes amostras: (a) inóculo e (b) reatores em batelada de enriquecimento

Figura 5.2. Bacilos curvos Gram-negativos em microscopia óptica de luz comum

Figura 5.3. Curva-padrão de crescimento de bactéria fototrófica púrpura não-sulfurosa

Figura 5.4. Crescimento celular e consumo de ácido acético da cultura de bactérias fototróficas púrpuras não-sulfurosas em reatores em batelada

Figura 5.5. Produção de hidrogênio para diferentes concentrações de ácido acético da cultura de bactérias fototróficas púrpuras não-sulfurosas em reatores em batelada

Figura 5.6. Crescimento celular e consumo de ácido acético para diferentes concentrações iniciais da cultura de bactérias fototróficas púrpuras nãosulfurosas em reatores em batelada

Figura 5.7. Produção de hidrogênio para diferentes concentrações iniciais da cultura de bactérias fototróficas púrpuras não-sulfurosas em reatores em batelada

Figura 5.8. Efeito da intensidade luminosa no crescimento celular (a); consumo de ácido acético (b) e na produção de hidrogênio (c)

Figura 5.9. Microscopia óptica de contraste de fase das amostras dos reatores em batelada alimentados com ácido acético nas seguintes concentrações: (a) $10 \mathrm{mmol} / \mathrm{L}$ e (b) $17 \mathrm{mmol} / \mathrm{L}$

Figura 5.10. Microscopia óptica de contraste de fase das amostras dos reatores em batelada inoculados com as seguintes concentrações de biomassa: (a) $0,02 \mathrm{~g} / \mathrm{L}$ e (b) $0,04 \mathrm{~g} / \mathrm{L}$

Figura 5.11. Microscopia óptica de contraste de fase das amostras dos reatores em batelada mantidos sob iluminação de: (a) 9000 a 10.000 lux e (b) 4000 a 5000 lux 
Figura 5.12. Microscopia óptica de contraste de fase das amostras dos reatores em batelada mantidos no escuro

Figura 5.13. Resultados das análises de DGGE dos fragmentos dos produtos de PCR amplificados com primers do Domínio Bacteria para as amostras: I - inóculo; 1 - ensaio com $10 \mathrm{mmol} / \mathrm{L}$ de ácido acético; 2 ensaio com $17 \mathrm{mmol} / \mathrm{L}$ de ácido acético; 3 - ensaio com $0,04 \mathrm{~g} / \mathrm{L}$ de biomassa; 4 - ensaio mantido sob iluminação de 4000 a 5000 lux; 5 - ensaio mantido no escuro

Figura 5.14. Crescimento celular da cultura de bactérias fototróficas púrpuras não-sulfurosas, na presença de diferentes substratos orgânicos

Figura 5.15. Produção de hidrogênio pela cultura de bactérias fototróficas púrpuras não-sulfurosas, na presença de diferentes substratos orgânicos

Figura 5.16. Predomínio de bacilos curvos aglomerados em formações de roseta, em microscopia óptica de contraste de fase de amostras dos frascos alimentados com: (a) acetato de sódio, (b) benzoato de sódio, (c) citrato de sódio, (d) fenol, (e) lactato de sódio e (f) metanol

Figura 5.17. Predomínio de bacilos curvos aglomerados em formações de roseta, em microscopia óptica de contraste de fase de amostras dos frascos alimentados com: (a) piruvato de sódio e (b) propionato de sódio

Figura 5.18. Microscopia óptica de contraste de fase de amostra do frasco alimentado com succinato de sódio

Figura 5.19. Predomínio de bacilos retos, em microscopia óptica de 57 contraste de fase de amostra do frasco alimentado com glutamato de sódio

Figura 5.20. Bacilos curvos aglomerados em formações de roseta, bacilos retos e filamentos, em microscopia óptica de contraste de fase de amostras dos frascos alimentados com: (a) butirato de sódio, (b) etanol, (c) frutose e (d) glicose

Figura 5.21. Foto dos frascos utilizados no ensaio de caracterização nutricional, mostrando as diferentes colorações da cultura em suspensão, na presença de diferentes substratos orgânicos 


\section{LISTA DE TABELAS}

Tabela 3.1 - Estudos sobre produção de hidrogênio por bactérias fototróficas

Tabela 4.1 - Composição do meio de cultura ATCC 112

Tabela 4.2 - Composição do meio de cultura para produção de hidrogênio

Tabela 4.3 - Composição da solução traço de metais

Tabela 4.4 - Composição dos reatores anaeróbios utilizados nos ensaios de produção de hidrogênio

Tabela 4.5 - Primers utilizados nas análises de PCR/DGGE

Tabela 4.6 - Programação do termociclador para amplificação dos fragmentos do DNAr 16S

Tabela 5.1 - Resultados obtidos nos ensaios de produção de hidrogênio

Tabela 5.2 - Crescimento celular, produção de hidrogênio, morfologias predominantes e coloração da cultura no ensaio de caracterização nutricional 


\section{LISTA DE ABREVIATURAS}

ATP - adenosina trifosfato

CAT - ciclo dos ácidos tricarboxílicos

$\mathrm{CO}_{2}$ - dióxido de carbono

$\mathrm{CO}_{\mathrm{x}}-$ óxidos de carbono

DGGE - eletroforese em gel de gradiente desnaturante

DNA - ácido desoxirribonucléico

DNAr - DNA ribossomal

FISH - hibridação in situ fluorescente

$\mathrm{H}_{2}$ - gás hidrogênio

$\mathrm{N}_{2}-$ gás nitrogênio

$\mathrm{NH}_{3}$ - amônia

$\mathrm{NH}_{4}^{+}$- íon amônio

$\mathrm{NO}_{\mathrm{x}}$ - óxidos de nitrogênio

PCR - reação de polimerização em cadeia

pH - potencial hidrogeniônico

PHB - poli- $\beta$-hidroxibutirato

RNA - ácido ribonucléico

RNAr - RNA ribossomal

rpm - rotação por minuto

$\mathrm{SO}_{\mathrm{x}}$ - óxidos de enxofre

Tg - tempo de geração

$\mu$ - velocidade específica de crescimento 


\section{SUMÁRIO}

RESUMO i

$\begin{array}{lll}\text { ABSTRACT } & \text { ii }\end{array}$

LISTA DE FIGURAS iii

LISTA DE TABELAS V v

LISTA DE ABREVIATURAS vi

1 INTRODUÇÃO 1

2 OBJETIVOS 3

$\begin{array}{lc}2.1 \text { Objetivos específicos } & 3\end{array}$

3 REVISÃO BIBLIOGRÁFICA

3.1 Hidrogênio como combustível $\quad 4$

$\begin{array}{ll}\text { 3.2 Produção biológica de hidrogênio } & 5\end{array}$

3.2.1 Microrganismos produtores de hidrogênio 6

$\begin{array}{ll}\text { 3.2.2 Enzimas envolvidas na produção biológica de hidrogênio } & 7\end{array}$

$\begin{array}{lr}\text { 3.2.3 Aparato fotossintético } & 8\end{array}$

$\begin{array}{ll}\text { 3.2.4 Esquema geral da produção fototrófica de hidrogênio } & 10\end{array}$

$\begin{array}{ll}\text { 3.2.5 Substratos para produção fototrófica de hidrogênio } & 12\end{array}$

$\begin{array}{ll}\text { 3.2.6 Sistema híbrido } & 16\end{array}$

4 MATERIAL E MÉTODOS 20

$\begin{array}{lr}\text { 4.1 Fluxograma experimental } & 20\end{array}$

4.2 Composição e preparo do meio de cultura e soluções estoque 23

$\begin{array}{ll}\text { 4.2.1 Meio de crescimento } & 23\end{array}$

4.2.2 Meio de cultura para produção de hidrogênio 23

$\begin{array}{ll}\text { 4.2.3 Solução traço de metais } & 24\end{array}$

4.2.4 Solução de vitamina $B_{12}$ 
4.2.5 Solução de acetato de sódio

4.2.6 Solução de glutamato de sódio

4.2.7 Soluções estoque dos substratos orgânicos

4.3 Enriquecimento de bactérias fototróficas púrpuras não-sulfurosas $\quad 27$

4.4 Enriquecimento em condições específicas para produção de hidrogênio 27

$\begin{array}{lr}\text { 4.5 Curva-padrão de crescimento } & 27\end{array}$

4.6 Ensaios de produção de hidrogênio 29

4.7 Determinação da velocidade específica de crescimento e tempo de $\mathbf{3 0}$ geração

$\begin{array}{ll}\text { 4.8 Caracterização nutricional } & 31\end{array}$

4.9 Análises cromatográficas

4.9.1 Determinação de hidrogênio 32

4.9.2 Determinação de ácido acético 33

4.10 Análise da intensidade luminosa 33

4.11 Análise da diversidade microbiana 34

$\begin{array}{ll}\text { 4.11.1 Exames microscópicos } & 34\end{array}$

4.11.2 Análise de biologia molecular 34

5 RESULTADOS E DISCUSSÃO 37

$\begin{array}{lr}\text { 5.1 Ensaios de enriquecimento } & 37\end{array}$

$\begin{array}{ll}\text { 5.2 Curva-padrão de crescimento } & 38\end{array}$

5.3 Ensaios de produção de hidrogênio

5.3.1 Exames microscópicos 49

$\begin{array}{lc}\text { 5.3.2 Biologia molecular } & 51\end{array}$

5.4 Caracterização nutricional

6 CONCLUSÕES 
8 REFERÊNCIAS BIBLIOGRÁFICAS

APÊNDICE 1 - Curva-padrão de crescimento de bactéria fototrófica 69 púrpura não-sulfurosa

APÊNDICE 2 - Tempo de experimento, valores de absorbância e 70 concentração de massa seca obtidos nos reatores anaeróbios em batelada

APÊNDICE 3 - Tempo de experimento, área cromatográfica e valores de 73 hidrogênio acumulado no headspace dos reatores anaeróbios em batelada

APÊNDICE 4 - Tempo de experimento e consumo de ácido acético nos 75 reatores anaeróbios em batelada

APÊNDICE 5 - Determinação da velocidade específica de crescimento e 78 tempo de geração

APÊNDICE 6 - Determinação da velocidade máxima de produção de 80 hidrogênio nos reatores anaeróbios em batelada

APÊNDICE 7 - Valores de massa seca e produção de hidrogênio do ensaio 87 de caracterização nutricional

ANEXO 1 - Curva de calibração do hidrogênio 


\section{INTRODUÇÃO}

Durante os últimos anos (1980-2004), quase 90\% da demanda de energia mundial foi satisfeita por combustíveis fósseis (INTERNATIONAL ENERGY ANNUAL, 2004). A ampla utilização destes combustíveis está causando mudanças no clima global devido, principalmente, a emissão de poluentes como óxidos de carbono $\left(\mathrm{CO}_{\mathrm{x}}\right)$, óxidos de nitrogênio $\left(\mathrm{NO}_{\mathrm{x}}\right)$, óxidos de enxofre $\left(\mathrm{SO}_{\mathrm{x}}\right)$, fuligem e compostos orgânicos, que são liberados na atmosfera durante a queima do combustível fóssil. O conhecimento da quantidade finita destes combustíveis na Terra e seu uso indiscriminado têm estimulado o desenvolvimento de novas fontes de energia menos poluentes e mais sustentáveis (DAS e VEZIROGLU, 2001).

Hidrogênio é considerado a energia limpa do futuro, pois gera somente água durante sua combustão, apresenta elevada conversão de energia por unidade de massa e pode ser convertido em energia elétrica, energia mecânica ou calor (KONDO et al., 2002). Prevê-se que a contribuição de hidrogênio para o consumo de energia global aumentará aproximadamente $50 \%$ ao final do século 21 , devido ao desenvolvimento de eficientes tecnologias de utilização do hidrogênio como combustível (HE et al., 2006).

Hidrogênio pode ser produzido por vários processos, incluindo eletrólise da água, reforma termocatalítica de compostos orgânicos ricos em hidrogênio e processos biológicos. Hidrogênio é produzido quase que exclusivamente pela reforma a vapor do metano (LEVIN et al., 2004). A produção do hidrogênio (biohidrogênio), usando microrganismos, é uma promissora área de desenvolvimento tecnológico a partir de ampla variedade de fontes renováveis.

Bactérias fototróficas são indicadas na literatura corrente como um dos mais promissores sistemas anoxigênicos para a produção biológica de hidrogênio. Os principais benefícios são os seguintes: elevado potencial teórico de produção; ausência de produção de oxigênio, o qual causa inativação de sistemas enzimáticos responsáveis pela produção de 
hidrogênio; capacidade de utilização de amplo espectro de luz; habilidade no consumo de substratos orgânicos derivados de resíduos e, conseqüentemente, potencial para ser usado em associação com tratamento de águas residuárias (DAS e VEZIROGLU, 2001).

O processo de fermentação anaeróbia no tratamento de águas residuárias tem como principais produtos o ácido acético e butírico. Pouco se sabe sobre a conversão destes ácidos a hidrogênio por bactérias fototróficas, e se esta conversão seria vantajosa a fim de acoplar a produção de energia com o tratamento de resíduos orgânicos. Dessa forma, este trabalho visou avaliar a produção de hidrogênio por bactéria fototrófica púrpura não-sulfurosa em reator em batelada, utilizando ácido acético como fonte de carbono. 


\section{OBJETIVOS}

O objetivo principal deste trabalho foi avaliar a produção de hidrogênio por cultura purificada de bactéria fototrófica púrpura não-sulfurosa em reator em batelada.

\subsection{Objetivos específicos}

- Avaliar o efeito das concentrações iniciais de ácido acético e biomassa na produção de hidrogênio por bactéria fototrófica púrpura não-sulfurosa;

- Verificar a influência da intensidade luminosa na produção fototrófica de hidrogênio, utilizando ácido acético como fonte de carbono;

- Caracterizar a diversidade microbiana da cultura purificada de bactéria fototrófica púrpura não-sulfurosa por meio de técnicas tradicionais de microbiologia e de biologia molecular;

- Avaliar o crescimento e a produção de hidrogênio da cultura purificada, na presença de diferentes substratos orgânicos. 


\section{REVISÃO BIBLIOGRÁFICA}

\subsection{Hidrogênio como combustível}

As necessidades de energia global são, na sua maioria, dependentes de combustíveis fósseis (INTERNATIONAL ENERGY ANNUAL, 2004). Contudo, sabe-se que as reservas desses combustíveis são escassas, e que esses compostos geram, como produto de sua combustão, substâncias potencializadoras do efeito estufa. Logo, a percepção de que as reservas de combustíveis fósseis são limitadas e de seus efeitos adversos ao ambiente têm nos forçado a investigar fontes alternativas de energia.

Hidrogênio é o elemento mais abundante, compondo quase três quartos de toda a massa do universo. Entretanto, hidrogênio não ocorre naturalmente como gás na Terra, mas combinado com outros elementos, tais como oxigênio, carbono e nitrogênio. Para que o hidrogênio possa ser utilizado como fonte energética, ele deve ser separado destes outros elementos e extraído na sua forma molecular, ou seja, hidrogênio gasoso $\left(\mathrm{H}_{2}\right)$.

Os vários processos de obtenção de hidrogênio incluem eletrólise da água, reforma termocatalítica de compostos orgânicos ricos em hidrogênio e processos biológicos. Entretanto, quase $95 \%$ do hidrogênio produzido provêm de reações do gás natural ou frações de óleo com vapor a elevadas temperaturas (reforma a vapor), ou seja, a tecnologia convencional de produção industrial de hidrogênio requer o consumo imediato ou indireto de combustíveis fósseis, resultando em emissão de dióxido de carbono $\left(\mathrm{CO}_{2}\right)$ e exaustão de combustíveis (LEVIN et al., 2004).

Muitas pesquisas têm sido conduzidas no desenvolvimento de tecnologia de produção de hidrogênio limpa, que dispensa a necessidade de combustíveis fósseis. Logo, o sistema de produção global de hidrogênio, inicialmente baseado em combustíveis fósseis, está mudando 
progressivamente em direção a fontes renováveis. Os pesquisadores exploram o uso de fontes como luz solar e biomassa para produzir hidrogênio economicamente.

Segundo Momirlan e Veziroglu (2005), hidrogênio é usado, principalmente, na manufatura de amônia, refinamento do petróleo e síntese de metanol. É também utilizado no programa espacial da NASA (National Aeronautics and Space Administration) como combustível de aeronaves espaciais, e em células que fornecem calor, eletricidade e água para os astronautas. Além disso, há diversos estudos sobre a aplicação de hidrogênio na indústria automobilística na forma de células combustíveis, dispositivos que convertem diretamente hidrogênio em eletricidade, assim como para gerar energia elétrica em residências e indústrias.

De acordo com He et al. (2006), a contribuição do hidrogênio para o consumo de energia global aumentará aproximadamente $50 \%$ ao final do século 21 , devido ao desenvolvimento de eficientes tecnologias de uso final, tornando o hidrogênio o principal abastecedor de energia. Entretanto, para este fim, será necessário que o hidrogênio seja produzido de maneira renovável e em larga escala.

\subsection{Produção biológica de hidrogênio}

Processos de produção biológica do hidrogênio são considerados ambientalmente corretos quando comparados aos processos termoquímicos e eletroquímicos. Processos biológicos são, geralmente, controlados por organismos fotossintéticos ou fermentativos e operados a temperatura e pressão ambientes, requerendo menores quantidades de energia. Além disso, a produção biológica de hidrogênio não somente leva a novo caminho para utilização de recursos como também facilita o tratamento de águas residuárias, uma vez que pode utilizar ampla variedade de resíduos como fonte de carbono e energia (DAS e VEZIROGLU, 2001). 


\subsubsection{Microrganismos produtores de hidrogênio}

Vários microrganismos, tais como bactérias fototróficas anoxigênicas, cianobactérias, algas ou bactérias fermentativas, são comumente utilizados para produção biológica de hidrogênio. Entre estes, as bactérias fototróficas anoxigênicas são organismos potenciais para produção em larga escala devido as suas elevadas eficiências de conversão e utilização de variedade de substrato, tanto para crescimento, como para produção de hidrogênio (KOKU et al., 2002).

As bactérias fototróficas anoxigênicas correspondem a grupo de microrganismos metabolicamente diverso e amplamente distribuído em ambientes anaeróbios expostos à luz. Os fototróficos anoxigênicos são semelhantes às plantas verdes por possuírem a habilidade de converter a energia da luz em energia química para o crescimento. Entretanto, diferentemente das plantas, não produzem oxigênio e, assim, são anoxigênicos. Além disso, possuem bacterioclorofila, que absorve principalmente a luz infravermelha (máximo de absorção entre 800 e $925 \mathrm{~nm}$ ), ao invés da luz vermelha de comprimento de onda curta (máximo de absorção entre 430 e $680 \mathrm{~nm}$ ) absorvida pela clorofila das plantas.

As células bacterianas também contêm carotenóides, pigmentos insolúveis em água que absorvem a energia da luz e a transmitem à bacterioclorofila. A cor destes carotenóides é a base para a divisão das bactérias fototróficas anoxigênicas em dois grupos principais: as bactérias "púrpuras" (laranja a vermelho-púrpura) e as "verdes" (verde a marrom). Tais bactérias são agrupadas, ainda, em relação à utilização de sulfetos, sendo divididas em sulfubactérias, púrpuras e verdes, e bactérias púrpuras e verdes não sulfurosas (MADIGAN et al., 2004).

A produção de hidrogênio dependente da luz realizada por bactéria fototrófica foi primeiramente observada por Gest e Kamen (1949) em culturas de Rhodospirillum rubrum Bactérias púrpuras não-sulforosas produzem hidrogênio e $\mathrm{CO}_{2}$ por meio da decomposição 
dependente da luz utilizando vários compostos orgânicos como doadores de elétrons para a fotossíntese. Esta reação ocorre sob iluminação, na presença de atmosfera inerte, anaeróbia, sob condições de limitação de nitrogênio, a partir da degradação de substratos orgânicos.

\subsubsection{Enzimas envolvidas na produção biológica de hidrogênio}

Todos os processos biológicos de produção de hidrogênio são fundamentalmente dependentes da presença de enzima produtora de hidrogênio. Bactérias fototróficas têm sido estudadas por sua capacidade de produzir hidrogênio através da ação de seu sistema nitrogenase (HALLENBECK e BENEMANN, 2002).

A enzima nitrogenase normalmente reduz nitrogênio molecular $\left(\mathrm{N}_{2}\right)$ a amônia $\left(\mathrm{NH}_{3}\right)$, mas também pode catalisar a produção de hidrogênio na ausência de $\mathrm{N}_{2}$, de acordo com a reação:

$$
2 \mathrm{H}^{+}+2 \mathrm{e}^{-}+4 \mathrm{ATP} \rightarrow \mathrm{H}_{2}+4 \mathrm{ADP}+4 \mathrm{P}_{\mathrm{i}}
$$

A eficiência de operação da nitrogenase requer elevadas quantidades de adenosina trifosfato (ATP) e poder de redução. Por esta razão, síntese e atividade desta enzima estão sujeitas a controles regulatórios rigorosos. Um problema na aplicação de bactérias fototróficas na produção de hidrogênio a partir de águas residuárias é como o íon amônio $\left(\mathrm{NH}_{4}{ }^{+}\right)$, que geralmente está presente na composição dessas águas, afeta a produção, e como evitar seu efeito inibitório, uma vez que $\mathrm{NH}_{4}{ }^{+}$reprime a síntese da nitrogenase (ZHU et al., 2001). Entretanto, esta inibição é reversível, e a nitrogenase recupera sua atividade quando o $\mathrm{NH}_{4}{ }^{+}$é consumido ou removido.

A presença de outra enzima, a hidrogenase, parece ser uma característica comum de bactérias fototróficas (KALIA et al., 2003). Contudo, uma vez que a produção de hidrogênio é atribuída principalmente a nitrogenase, a atividade de produção de hidrogênio pela hidrogenase é desprezível. Esta enzima é geralmente aceita como "antagonista metabólico" da 
nitrogenase, assumindo a função de consumidora de hidrogênio (HALLENBECK e BENEMANN, 2002). Logo, a atividade da hidrogenase é crítica para a produção fotoheterotrófica de hidrogênio, e são numerosos os esforços para eliminar a capacidade dos organismos de sintetizar esta enzima, o que resulta, usualmente, em aumento na produção de hidrogênio.

Ooshima et al. (1998) investigaram a produção de hidrogênio por Rhodobacter capsulatus ST410, uma linhagem mutante da bactéria fototrófica Rhodobacter capsulatus B100. A linhagem mutante ST410 exibiu carência da atividade hidrogenase e apresentou produção de hidrogênio (3,3 $\mathrm{L} \quad \mathrm{H}_{2} / \mathrm{L}$ cultura) maior que a linhagem selvagem $\mathrm{B} 100$ (2,1 $\mathrm{L} \mathrm{H}_{2} / \mathrm{L}$ cultura), quando foram utilizados $30 \mathrm{mmol} / \mathrm{L}$ de malato e $7 \mathrm{mmol} / \mathrm{L}$ de glutamato como fontes de carbono e nitrogênio, respectivamente, a $33^{\circ} \mathrm{C}$ e intensidade luminosa de 6600 lux.

\subsubsection{Aparato Fotossintético}

A energia requerida para crescimento, bem como para a atividade de produção de hidrogênio da nitrogenase são fornecidas pelo aparato fotossintético, que converte energia luminosa em energia química (ATP). O aparato fotossintético é composto de um "complexo antena" de dez a centenas de moléculas de pigmentos que absorvem luz e um "centro de reação", que consiste de uma molécula extremamente especializada a qual transforma energia luminosa em energia química (AKKERMAN et al., 2002).

Oxigênio é o regulador primário da síntese do aparato fotossintético; sua presença reprime imediatamente a síntese de moléculas de bacterioclorofila, que são responsáveis pela absorção de luz. O efeito é reversível e a síntese é retomada assim que o oxigênio é eliminado. A luz também controla a síntese, mas seu efeito não é tão efetivo quanto o do oxigênio. Em 
atmosfera anaeróbia, o número de vesículas fotossintéticas produzidas varia inversamente com a intensidade de luz incidente (KOKU et al., 2002).

A produção de hidrogênio é catalisada pela nitrogenase sob suprimento de ATP e poder de redução, ambos fornecidos pelo sistema fotossintético. A eficiência de conversão de energia luminosa a hidrogênio é o fator chave na produção de hidrogênio. Logo, a avaliação dessa eficiência é necessária antes que tais sistemas possam ser aplicados em escala real.

Quando a luz penetra na suspensão celular e vai para o fundo do reator, sua intensidade declina exponencialmente. Uma vez que a produção de hidrogênio depende da disponibilidade de energia luminosa, a produção de hidrogênio decresce com aumento da profundidade. Nakada et al. (1995) investigaram a saturação de luz e estimaram a taxa de produção de hidrogênio e a eficiência de conversão a várias profundidades de penetração de luz em reator, usando Rhodobacter sphaeroides RV e iluminação superficial. Os autores demonstraram que a velocidade de produção de hidrogênio decresceu rapidamente com o aumento da profundidade de penetração devido à distribuição heterogênea de luz.

Contudo, sob forte intensidade de luz (acima de 10.000 lux) ocorre saturação luminosa, porque o sistema fotossintético fornece quantidades excessivas de ATP e poder de redução comparada à capacidade da nitrogenase. Esta é a razão porque a eficiência de conversão decresce sob elevadas intensidades luminosas. Há, ainda, outra razão para a redução da eficiência de conversão luminosa, nomeada "efeito sombreador", no qual a penetração de luz é limitada pelos pigmentos no sistema fotossintético, que estão presentes em excesso para o crescimento celular (KONDO et al., 2002). Em ambos os mecanismos de redução da eficiência de conversão, a quantidade de pigmentos é considerada essencial.

Barbosa et al. (2001) estudaram o efeito da intensidade luminosa na produção de hidrogênio por três diferentes linhagens de bactérias fototróficas, utilizando acetato como fonte de carbono. Os autores demonstraram que sob baixa intensidade luminosa 
(40 $\mu \mathrm{mol}$ fótons $/ \mathrm{m}^{2} . \mathrm{s}$ ) ocorreu maior eficiência luminosa e menor produção de $\mathrm{H}_{2}$. De acordo com os autores, a grande diferença entre eficiências luminosas quando baixa (40 $\mu \mathrm{mol}$ fótons $\left./ \mathrm{m}^{2} . \mathrm{s}\right)$ e alta intensidade de luz (680 $\mu \mathrm{mol}$ fótons $\left./ \mathrm{m}^{2} . \mathrm{s}\right)$ são fornecidas deve ser devido ao fato de que para altas intensidades luminosas nem toda luz é absorvida. A outra razão poderia ser o fornecimento de energia em excesso da capacidade da enzima de produção de hidrogênio (nitrogenase) quando a intensidade de luz é alta, levando à baixa efíciência de conversão.

Um método promissor para suprimir saturação luminosa é reduzir os pigmentos fotossintéticos dos complexos captadores de luz em células bacterianas. Kondo et al. (2002) tentaram solucionar o problema de saturação luminosa produzindo linhagem mutante, MTP4, com quantidade reduzida de pigmentos, a partir de uma linhagem selvagem de Rhodobacter sphaeroides RV. Os autores utilizaram lactato de sódio $(50 \mathrm{mmol} / \mathrm{L})$ como fonte de carbono e verificaram que a supressão da saturação de luz aumentou a taxa de produção de hidrogênio, sob intensidade luminosa de 16.000 lux, a $30^{\circ} \mathrm{C}$ por 24 horas. Logo, MTP4 foi capaz de produzir mais hidrogênio que $R$. sphaeroides RV.

\subsubsection{Esquema geral da produção fototrófica de hidrogênio}

De acordo com Koku et al. (2002), o esquema geral de produção fototrófica de hidrogênio pode ser descrito como na Figura 3.1. O substrato orgânico entra no ciclo dos ácidos tricarboxílicos (CAT), ou ciclo do ácido cítrico, onde é oxidado para produzir $\mathrm{CO}_{2} \mathrm{e}$ elétrons. Trabalhando em paralelo está o aparato da membrana fotossintética, o qual converte a energia luminosa em ATP. Este ATP é encaminhado para a nitrogenase junto com os prótons e elétrons. Prótons são fornecidos em parte pelo ciclo CAT, e o restante é fornecido pela ação da ATP-sintase do aparato fotossintético. Finalmente, a nitrogenase reduz os prótons a hidrogênio molecular. Hidrogenase funciona primariamente na direção de consumo 
de hidrogênio, produzindo ATP, prótons e elétrons. A quantidade líquida de hidrogênio produzido é, então, a quantidade produzida pela nitrogenase menos a consumida pela hidrogenase.

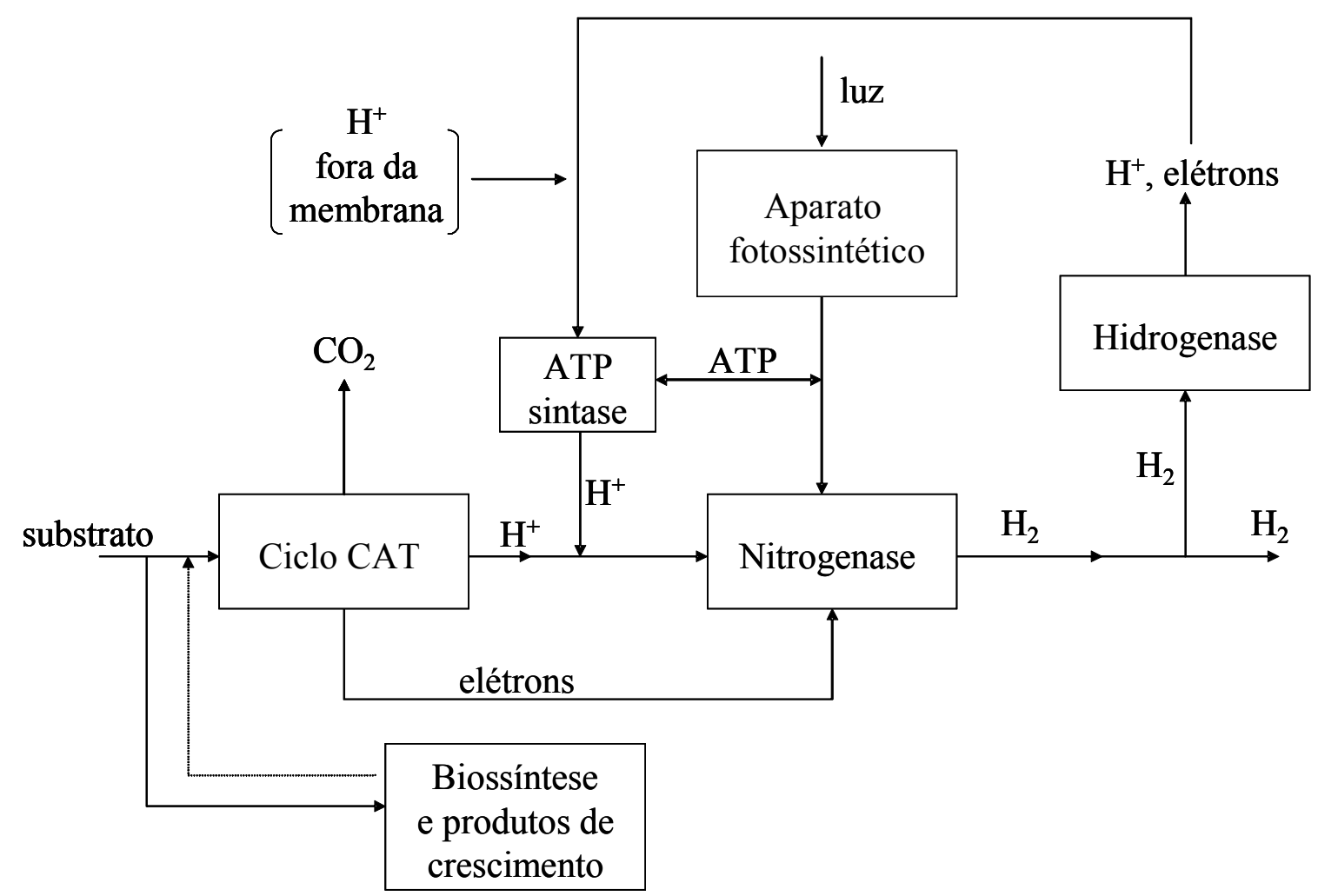

Figura 3.1. Esquema geral de produção de hidrogênio por bactérias fototróficas púrpuras nãosulfurosas

Fonte: Koku et al. (2002)

De acordo com o esquema descrito acima, a produção de hidrogênio por bactérias fototróficas púrpuras não-sulfurosas acontece através da ação do ciclo do ácido cítrico anaeróbio dependente da luz (ciclo CAT). Quando a nitrogenase é inibida ou reprimida, a atividade do ciclo CAT é severamente limitada e caminhos alternativos, como a síntese de polissacarídeos, podem ser seguidos. Efeito similar ocorre quando a relação carbono/nitrogênio é baixa, resultando em acúmulo de amônia e inibição da nitrogenase (KOKU et al., 2002). 
Entre os processos metabólitos alternativos à produção de hidrogênio tem-se a formação do material de reserva, poli- $\beta$-hidroxibutirato (PHB), particularmente importante do ponto de vista de desenvolvimento do processo, uma vez que o PHB tem valor econômico como polímero biodegradável.

Vincenzini et al. (1997) estudaram a viabilidade do processo de fotoprodução de hidrogênio molecular e material de reserva celular (poli- $\beta$-hidroxibutirato, PHB), utilizando culturas semi-contínuas em batelada de Rhodopseudomonas palustris 42OL em condições de limitação de nitrogênio, a $30^{\circ} \mathrm{C}$ e contínua iluminação com lâmpada incandescente de 1000 W. A condição de limitação de nitrogênio estimula não só a produção de $\mathrm{H}_{2}$ dependente da nitrogenase, como também o acúmulo intracelular de reservas de carbono. Sob tal condição, R. palustris converteu preferencialmente o substrato malato $(7 \mathrm{~g} / \mathrm{L})$ em $\mathrm{H}_{2}$, enquanto que o acúmulo de PHB teve importância relativamente menor.

\subsubsection{Substratos para produção fototrófica de hidrogênio}

Bactérias fototróficas púrpuras não-sulforosas são capazes de utilizar ampla variedade de substratos como fontes de carbono e nitrogênio. Embora estes substratos possam ser utilizados para crescimento, somente uma porção deles está disponível para produção de hidrogênio. Em geral, os substratos preferidos são ânions de ácidos orgânicos tais como lactato e malato. Os caminhos metabólicos de utilização são extensos e podem diferir entre espécies ou entre diferentes linhagens da mesma espécie (KOKU et al., 2002).

Dois critérios são freqüentemente usados para avaliar o desempenho da produção de hidrogênio a partir de um substrato específico. O primeiro refere-se à velocidade de produção de hidrogênio (quantidade/tempo) com base na concentração de biomassa ou peso seco bacteriano. O segundo refere-se à eficiência de conversão do substrato, ou seja, quanto foi utilizado para produção de hidrogênio e não para crescimento ou biossíntese. Este último é a 
razão entre mols reais de hidrogênio produzidos pela quantidade teórica que teria sido obtida se todo o substrato fosse utilizado para produção de hidrogênio e dióxido de carbono, de acordo com a seguinte reação hipotética:

$\mathrm{C}_{\mathrm{x}} \mathrm{H}_{\mathrm{y}} \mathrm{O}_{\mathrm{z}}+(2 \mathrm{x}-\mathrm{z}) \mathrm{H}_{2} \mathrm{O} \rightarrow(\mathrm{y} / 2+2 \mathrm{x}-\mathrm{z}) \mathrm{H}_{2}+\mathrm{xCO}_{2}$

Zürrer e Bachofen (1979) estudaram a produção fototrófica de hidrogênio em culturas em batelada de Rhodospirillum rubrum S-1, a $30^{\circ} \mathrm{C}$ e intensidade luminosa de 10.000 lux. Velocidades de produção de $0,065 \mathrm{~L} \mathrm{H}_{2} /$ L.h foram alcançadas, utilizando glutamato (15 mmol/L) como fonte de nitrogênio e lactato $(50 \mathrm{mmol} / \mathrm{L})$ como doador de elétrons.

Fedorov et al. (1998) avaliaram a produção de hidrogênio por Rhodobacter sphaeroides GL-1 imobilizada em espuma de poliuretano, em reator de fluxo contínuo, com ácido lático (40 mmol/L) como fonte de carbono. A velocidade de produção foi 0,061 $\mathrm{L} \mathrm{H}_{2} /$ L.h, com eficiência de conversão de 86\% de ácido lático, sob intensidade luminosa de 16.000 lux. De acordo com os autores, geralmente, as velocidades volumétricas de produção de hidrogênio por células imobilizadas são maiores que por células livres. Os autores concluíram que a espuma de poliuretano é uma matriz apropriada para imobilizar bactéria púrpura para produção de hidrogênio, contudo a principal desvantagem residiu na lentidão do procedimento de imobilização.

Eroglu et al. (1999) investigaram o efeito das concentrações iniciais de ácido málico $(7,5 ; 15$ e $30 \mathrm{mmol} / \mathrm{L})$ e glutamato de sódio $(1,2$ e $10 \mathrm{mmol} / \mathrm{L})$ na produção de hidrogênio por Rhodobacter sphaeroides O.U.001. Fotobiorreator de coluna, que consistia de cilindro de vidro com volume interno de $400 \mathrm{~mL}$, foi operado a $32^{\circ} \mathrm{C}$ e iluminado com lâmpada de tungstênio à intensidade luminosa de 10.000 lux. Os autores observaram que excesso de glutamato de sódio $(10 \mathrm{mmol} / \mathrm{L})$ intensificou o crescimento celular, porém inibiu a produção de hidrogênio. Todavia, elevadas concentrações de ácido málico (30 mmol/L) e reduzidas concentrações de glutamato de sódio $(1 \mathrm{mmol} / \mathrm{L})$ aumentaram, tanto o crescimento celular, 
como a produção de hidrogênio. A máxima velocidade de produção de hidrogênio observada foi $0,01 \mathrm{~L} \mathrm{H}_{2} / \mathrm{L} . h$, com meio de crescimento contendo concentrações iniciais de $15 \mathrm{mmol} / \mathrm{L}$ de ácido málico e $2 \mathrm{mmol} / \mathrm{L}$ de glutamato de sódio.

Barbosa et al. (2001) utilizaram quatro diferentes ácidos orgânicos de cadeia curta, lactato $(50 \mathrm{mmol} / \mathrm{L})$, malato $(15 \mathrm{mmol} / \mathrm{L})$, acetato $(6,11$ e $22 \mathrm{mmol} / \mathrm{L})$ e butirato (27 mmol/L), como fonte de carbono para produção de hidrogênio, e três diferentes linhagens de bactérias fototróficas: Rhodopseudomonas sp., Rhodopseudomonas palustris e uma linhagem não-identificada, em reatores em batelada. Os experimentos foram realizados a $30^{\circ} \mathrm{C}$ e a fonte de nitrogênio utilizada foi glutamato de sódio $(0,8 \mathrm{mmol} / \mathrm{L})$. Duas lâmpadas de halogênio/tungstênio foram colocadas em lados opostos dos reatores, sendo as intensidades luminosas estudadas de 40 e $600 \mu \mathrm{mol}$ fótons $/ \mathrm{m}^{2}$.s. As maiores eficiências de conversão (72,8\%) e velocidade de produção de hidrogênio (0,025 L $\mathrm{H}_{2} /$ L.h) foram atingidas por Rhodopseudomonas sp. com acetato (22 mmol/L) como fonte de carbono.

Fang et al. (2005) utilizaram como substrato para produção fototrófica de hidrogênio acetato $(10$ a $50 \mathrm{mmol} / \mathrm{L})$ e butirato $(10$ a $60 \mathrm{mmol} / \mathrm{L})$, que são os principais produtos da fermentação. Por meio de experimentos em batelada foram avaliados os efeitos do $\mathrm{pH}$ inicial (entre 5,0 e 10,0) e das concentrações individuais dos substratos na produção de hidrogênio. Os experimentos foram conduzidos a $32^{\circ} \mathrm{C}$ e sob intensidade luminosa de 10.000 lux. Foram

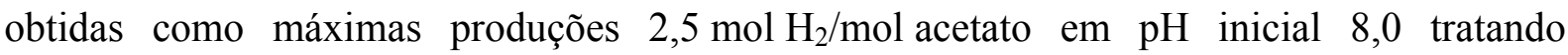
$10 \mathrm{mmol} / \mathrm{L}$ de acetato e $3,7 \mathrm{~mol} \mathrm{H}_{2} / \mathrm{mol}$ butirato em $\mathrm{pH}$ inicial 9,0 tratando $10 \mathrm{mmol} / \mathrm{L}$ de butirato. As análises do perfil das bandas de DGGE de fragmentos de DNAr 16S e imagens de FISH, revelaram a predominância de bactérias semelhantes a Rhodobacter capsulatus com mais de $80 \%$ de abundância relativa, na biomassa utilizada para produção fototrófica de hidrogênio. 
Quatro diferentes linhagens mutantes de Rhodobacter capsulatus (IR1, IR3, IR4 e JP91) foram testadas por He et al. (2005) por sua habilidade em produzir hidrogênio. Foram utilizados fotobiorreatores $(3,5 \mathrm{~L})$ com lactato $(30 \mathrm{mmol} / \mathrm{L})$ e glutamato $(5 \mathrm{mmol} / \mathrm{L})$ como fontes de carbono e nitrogênio, respectivamente. A temperatura foi controlada a $30^{\circ} \mathrm{C}$ e a iluminação foi fornecida por duas lâmpadas incandescentes de 120 W cada, dispostas a distância de $1 \mathrm{~m}$ dos reatores. A linhagem IR3 foi a que apresentou maior produção de hidrogênio, com eficiência de conversão de substrato de $84,8 \%$ e produção de $3,9 \mathrm{~L} \mathrm{H}_{2} / \mathrm{L}$ de cultura.

A produção biológica de hidrogênio vem sendo amplamente estudada, uma vez que não consome recursos fósseis. Sendo assim, é de importância considerável a utilização de substratos complexos, como águas residuárias, uma vez que a produção de energia e o tratamento dessas águas podem ocorrer simultaneamente.

A fotoprodução de hidrogênio por células de Rhodopseudomonas palustris e Rhodospirillum molischianum, imobilizadas em gel de ágar, foi investigada por Vincenzini et al. (1982). Os reatores foram iluminados com lâmpadas de tungstênio a 5500 lux. Foram utilizados efluentes de refinaria de açúcar e de indústria de papel como doadores de elétrons. As máximas produções foram de 2,2 e 2,6 L H $\mathrm{H}_{2} / \mathrm{L}$ cultura, para $R$. palustris e $R$. molischianum respectivamente, a partir do efluente de indústria de papel.

Sasikala et al. (1992) utilizaram água residuária diluída $(10 \% \mathrm{v} / \mathrm{v})$ proveniente de destilaria e verificaram produção de hidrogênio de $0,996 \mathrm{~L} \mathrm{H}_{2} / \mathrm{L}$ com cultura de Rhodobacter sphaeroides O.U.001 com células planctônicas e 3,094 L H $\mathrm{H}_{2} / \mathrm{L}$ com células imobilizadas em alginato de cálcio. Segundo os autores, o crescimento e a produção de hidrogênio por células planctônicas são inibidos se a concentração de água residuária for maior que $10 \%$ devido às elevadas concentrações de substrato, resultando em estresse osmótico e/ou presença de inibidores. Contudo, quando se utilizou célula imobilizada houve atenuação da inibição, 
devido a concentrações relativamente menores dos constituintes da água residuária em função da difusão do substrato na matriz na qual as células estavam imobilizadas.

Produção de hidrogênio a partir de água residuária de produção de queijo de soja (tofu) foi examinada por Zhu et al. (1999) utilizando bactéria fototrófica anoxigênica Rhodobacter sphaeroides RV imobilizada em gel de agar. Células foram cultivadas em condições de anaerobiose e sob iluminação de lâmpadas de tungstênio com intensidade luminosa na superfície do gel de 8000 lux. A produção de hidrogênio foi acompanhada até $120 \mathrm{~h}$, e atingiu rendimento de $1,9 \mathrm{~L} \mathrm{H}_{2} / \mathrm{L}$ cultura, o que correspondeu a quase $15 \%$ da máxima produção teórica a partir da água residuária utilizada. De acordo com os autores, a imobilização protegeu a produção de hidrogênio da inibição por amônio, uma vez que a difusão deste na matriz do gel foi dificultada.

Yetis et al. (2000) utilizaram água residuária de refinamento de açúcar (sugar refinery wastewater - SRWW) como fonte de carbono para produção de hidrogênio por Rhodobacter sphaeroides O.U.001, em experimentos em batelada. A temperatura foi mantida a $32^{\circ} \mathrm{C}$ e a intensidade luminosa em 10.000 lux na superfície externa dos reatores. Os autores obtiveram nenhuma ou pouca produção de hidrogênio sob diferentes diluições de água residuária, entretanto, quando malato foi adicionado à água residuária diluída a 20\%, para ajustar o conteúdo de carbono a $70 \mathrm{mmol} / \mathrm{L}$, obteve-se máxima produção de $2,67 \mathrm{~L} \mathrm{H}_{2} / \mathrm{L}$ de cultura.

Os resultados obtidos demonstram a possibilidade de utilizar bactérias fototróficas anoxigênicas em processos de produção de hidrogênio concomitante ao tratamento de águas residuárias.

\subsubsection{Sistema híbrido}

Abordagem promissora para altas taxas de produção de hidrogênio a partir de águas residuárias é o pré-tratamento dos resíduos por fermentação acidogênica, a fim de produzir 
substratos favoráveis à produção fototrófica. Em tal sistema, também conhecido como híbrido, a fermentação anaeróbia de resíduos orgânicos produz intermediários como ácidos orgânicos de baixa massa molecular, que são então convertidos a hidrogênio por bactérias fototróficas à custa de energia luminosa, em uma segunda etapa.

Fascetti et al. (1998) cultivaram células de Rhodobacter sphaeroides RV em soluções contendo lactato, derivadas da acidogênese de resíduos sólidos municipais. Os experimentos mostraram que a solução ácida obtida de tal rejeito foi substrato adequado para o crescimento de $R$. sphaeroides. Todavia, a produção de hidrogênio requereu adição de microelementos externos, tais como ferro e, principalmente, molibdênio. Quando estes elementos estiveram presentes, reatores operados com tempo de detenção hidráulica (TDH) de 25 h, temperatura de $30^{\circ} \mathrm{C}$, pH 7,2 e iluminação contínua de 10.000 lux, obtiveram produção estável de hidrogênio durante 8 a 10 dias com velocidade de $100 \mathrm{~mL} \mathrm{H}_{2} /$ g peso seco.h.

Yokoi et al. (1998) observaram a produção de hidrogênio por cultura em batelada de duas fases, composta por Clostridium butyricum e Rhodobacter sp. M-19, e também por cultura mista de C. butyricum e Rhodobacter sp. M-19, ambas cultivadas anaerobiamente a $30^{\circ} \mathrm{C}$ e sob iluminação de 5000 lux. Foram obtidos rendimentos de $3,6 \mathrm{~mol} \mathrm{H}_{2} / \mathrm{mol}$ glicose e 6,6 $\mathrm{mol} \mathrm{H}_{2} / \mathrm{mol}$ glicose para cultura de duas fases e cultura mista, respectivamente, indicando a superioridade da segunda sobre a primeira.

Efetiva produção de hidrogênio a partir de água residuária contendo amido foi investigada por Yokoi et al. (2002) utilizando Clostridium butyricum, Enterobacter aerogenes e Rhodobacter sp. M-19. A bactéria fototrófica Rhodobacter sp. M-19 foi cultivada a $35^{\circ} \mathrm{C}$, sob iluminação de 5000 lux, por lâmpadas incandescentes. Foram realizados ensaios em batelada com cultura mista de Clostridium butyricum e Enterobacter aerogenes em água residuária contendo amido, sendo, posteriormente, o sobrenadante desta cultura utilizado como fonte de carbono nos ensaios em batelada com Rhodobacter sp. M-19. Totalizando as 
produções individuais alcançadas pelas culturas, obteve-se rendimento total de 7,2 $\mathrm{mol} \mathrm{H} / 2 / \mathrm{mol}$ glicose.

Na Tabela 3.1 estão descritos os resumos dos trabalhos sobre produção de hidrogênio por bactérias fototróficas anoxigênicas. Cabe ressaltar a dificuldade de padronização de unidades com relação à máxima produção de hidrogênio obtida em cada trabalho, uma vez que cada autor utiliza diferentes unidades de medida e, em alguns trabalhos os dados fornecidos são insuficientes para realização de conversão de unidades. 
Tabela 3.1 - Estudos sobre produção de hidrogênio por bactérias fototróficas

\begin{tabular}{|c|c|c|c|c|c|c|c|}
\hline Organismo & $\begin{array}{l}\text { Fonte de } \\
\text { carbono }\end{array}$ & $\begin{array}{c}\text { Fonte de } \\
\text { nitrogênio }\end{array}$ & $\begin{array}{c}\text { Temp } \\
\left({ }^{\circ} \mathrm{C}\right)\end{array}$ & Luz & Reator & $\begin{array}{c}\text { Máxima } \\
\text { produção de } \mathrm{H}_{2}\end{array}$ & Referência \\
\hline $\begin{array}{l}\text { Rhodospirillum } \\
\text { rubrum S-1 }\end{array}$ & $\begin{array}{l}\text { Lactato } \\
(50 \\
\mathrm{mmol} / \mathrm{L})\end{array}$ & $\begin{array}{l}\text { Glutamato } \\
\qquad(15 \\
\mathrm{mmol} / \mathrm{L})\end{array}$ & 30 & $\begin{array}{c}10000 \\
\operatorname{lux}\end{array}$ & Batelada & $\begin{array}{c}0,065 \mathrm{~L} \mathrm{H}_{2} \mathrm{~L}^{-1} \\
\mathrm{~h}^{-1}\end{array}$ & $\begin{array}{c}\text { Zürrer \& } \\
\text { Bachofen } \\
(1979)\end{array}$ \\
\hline $\begin{array}{c}\text { Rhodobacter } \\
\text { sphaeroides GL-1 }\end{array}$ & $\begin{array}{l}\text { Ác. lático } \\
\quad(40 \\
\mathrm{mmol} / \mathrm{L})\end{array}$ & $\begin{array}{c}\left(\mathrm{NH}_{4}\right)_{2} \mathrm{SO}_{4} \\
(4 \\
\mathrm{mmol} / \mathrm{L})\end{array}$ & 31 & $\begin{array}{l}16000 \\
\operatorname{lux}\end{array}$ & $\begin{array}{c}\text { Fluxo } \\
\text { contínuo }\end{array}$ & $0,061 \underset{\mathrm{h}^{-1}}{\mathrm{~L} \mathrm{H}_{2}} \mathrm{~L}^{-1}$ & $\begin{array}{l}\text { Federov et } \\
\text { al. (1998) }\end{array}$ \\
\hline $\begin{array}{c}\text { Rhodobacter } \\
\text { sphaeroides } \\
\text { O.U.001 }\end{array}$ & $\begin{array}{c}\text { Ác. } \\
\text { málico } \\
(7,5 ; 15 \mathrm{e} \\
30 \\
\mathrm{mmol} / \mathrm{L})\end{array}$ & $\begin{array}{l}\text { Glutamato } \\
(1 ; 2 \text { e } 10 \\
\mathrm{mmol} / \mathrm{L})\end{array}$ & 32 & $\begin{array}{l}10000 \\
\operatorname{lux}\end{array}$ & Coluna & $0,01 \mathrm{~L} \mathrm{H}_{2} \mathrm{~L}^{-1} \mathrm{~h}^{-1}$ & $\begin{array}{l}\text { Eroglu et } \\
\text { al. (1999) }\end{array}$ \\
\hline $\begin{array}{l}\text { Rhodopseudomonas } \\
\text { sp. } \\
\text { Rhodopseudomonas } \\
\text { palustris } \\
\text { Linhagem não- } \\
\text { identificada }\end{array}$ & $\begin{array}{c}\text { Lactato } \\
(50 \\
\text { mmol/L) } \\
\text { Malato } \\
(15 \\
\text { mmol/L) } \\
\text { Acetato } \\
\text { (6; } 11 \text { e } 22 \\
\text { mmol/L) } \\
\text { Butirato } \\
(27 \\
\text { mmol/L) }\end{array}$ & $\begin{array}{c}\text { Glutamato } \\
\qquad(0,8 \\
\mathrm{mmol} / \mathrm{L})\end{array}$ & 30 & $\begin{array}{c}40 \mathrm{e} \\
600 \\
\mu \mathrm{mol} \\
\text { fótons } \\
\mathrm{m}^{-2} \mathrm{~s}^{-1}\end{array}$ & Batelada & $\underset{\mathrm{h}^{-1}}{0,025 \mathrm{~L} \mathrm{H}_{2} \mathrm{~L}^{-1}}$ & $\begin{array}{l}\text { Barbosa et } \\
\text { al. (2001) }\end{array}$ \\
\hline $\begin{array}{c}\text { Cultura fototrófica } \\
\text { mista }\end{array}$ & $\begin{array}{l}\text { Acetato } \\
(10 \text { a } 50 \\
\text { mmol/L) } \\
\text { Butirato } \\
(10 \text { a } 60 \\
\mathrm{mmol} / \mathrm{L})\end{array}$ & 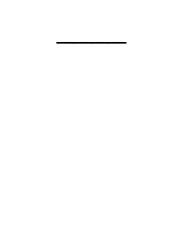 & 32 & $\begin{array}{c}10000 \\
\operatorname{lux}\end{array}$ & Batelada & $\begin{array}{l}2,5 \mathrm{~mol} \mathrm{H}_{2} / \mathrm{mol} \\
\text { acetato } \\
3,7 \mathrm{~mol} \mathrm{H}_{2} / \mathrm{mol} \\
\text { butirato }\end{array}$ & $\begin{array}{c}\text { Fang et al. } \\
\text { (2005) }\end{array}$ \\
\hline $\begin{array}{c}\text { Rhodobacter } \\
\text { capsulatus }\end{array}$ & $\begin{array}{l}\text { Lactato } \\
\qquad(30 \\
\mathrm{mmol} / \mathrm{L})\end{array}$ & $\begin{array}{l}\text { Glutamato } \\
\qquad(5 \\
\mathrm{mmol} / \mathrm{L})\end{array}$ & 30 & $240 \mathrm{~W}$ & Batelada & $\begin{array}{c}3,9 \mathrm{~L} \mathrm{H}_{2} \mathrm{~L}^{-1} \\
\text { cultura }\end{array}$ & $\begin{array}{l}\text { He et al. } \\
(2005)\end{array}$ \\
\hline $\begin{array}{c}\text { Rhodopseudomonas } \\
\text { palustris } \\
\text { Rhodospirillum } \\
\text { molischianum }\end{array}$ & $\begin{array}{l}\text { Efluente } \\
\text { de } \\
\text { indústria } \\
\text { de papel }\end{array}$ & & 30 & $\begin{array}{l}5500 \\
\operatorname{lux}\end{array}$ & Gel de ágar & $\begin{array}{l}2,2 \mathrm{~L} \mathrm{H}_{2} \mathrm{~L}^{-1} \\
\text { cultura } \\
\text { 2,6 } 6 \mathrm{~L} \mathrm{H}_{2} \mathrm{~L}^{-1} \\
\text { cultura }\end{array}$ & $\begin{array}{l}\text { Vincenzini } \\
\text { et al. } \\
(1982)\end{array}$ \\
\hline $\begin{array}{c}\text { Rhodobacter } \\
\text { sphaeroides } \\
\text { O.U.001 }\end{array}$ & $\begin{array}{c}\text { Efluente } \\
\text { de } \\
\text { destilaria }\end{array}$ & & 30 & $\begin{array}{c}3000 \\
\operatorname{lux}\end{array}$ & $\begin{array}{l}\text { Céls. livres/ } \\
\text { imobilizadas } \\
\text { alginato de } \\
\text { cálcio }\end{array}$ & $\begin{array}{l}0,996 \mathrm{~L} \mathrm{H}_{2} \mathrm{~L}^{-1} \\
\text { cultura } \\
3,094 \mathrm{~L} \mathrm{H}_{2} \mathrm{~L}^{-1} \\
\text { cultura }\end{array}$ & $\begin{array}{l}\text { Sasikala et } \\
\text { al. (1992) }\end{array}$ \\
\hline $\begin{array}{c}\text { Rhodobacter } \\
\text { sphaeroides RV }\end{array}$ & $\begin{array}{l}\text { Efluente } \\
\text { de usina } \\
\text { de soja }\end{array}$ & & 30 & $\begin{array}{l}8000 \\
\operatorname{lux}\end{array}$ & Gel de ágar & $\begin{array}{l}1,9 \mathrm{~L} \mathrm{H}_{2} \mathrm{~L}^{-1} \\
\text { cultura }\end{array}$ & $\begin{array}{l}\text { Zhu et al. } \\
\text { (1999) }\end{array}$ \\
\hline $\begin{array}{c}\text { Rhodobacter } \\
\text { sphaeroides } \\
\text { O.U.001 }\end{array}$ & $\begin{array}{l}\text { Efluente } \\
\text { de } \\
\text { refinaria } \\
\text { de açúcar }\end{array}$ & & 32 & $\begin{array}{l}10000 \\
\operatorname{lux}\end{array}$ & Batelada & $\begin{array}{c}2,67 \mathrm{~L} \mathrm{H}_{2} \mathrm{~L}^{-1} \\
\text { cultura }\end{array}$ & $\begin{array}{l}\text { Yetis et al. } \\
\quad(2000)\end{array}$ \\
\hline
\end{tabular}




\section{MATERIAL E MÉTODOS}

\subsection{Fluxograma experimental}

Para a realização dos experimentos foi utilizado, como inóculo, bactéria fototrófica púrpura não-sulfurosa previamente purificada por Saavedra et al. (2005), proveniente da lagoa de estabilização anaeróbia de Cajati, Vale do Ribeira (São Paulo - Brasil).

As atividades experimentais realizadas neste trabalho estão descritas cronologicamente na Figura 4.1. O inóculo foi enriquecido em meio ATCC 112 (VAN NIEL, 1944) específico para bactérias fototróficas púrpuras não-sulfurosas. Após crescimento microbiano, foi realizada lavagem da biomassa, por centrifugação para retirada de compostos intermediários do final do crescimento celular. $\mathrm{O}$ inóculo foi então enriquecido novamente, porém em condições específicas para produção de hidrogênio (meio FANG et al., 2005), com a finalidade de adaptar a cultura as novas condições de cultivo.

Para medida de crescimento foi realizado ensaio relacionando massa seca celular e densidade óptica. Os ensaios de produção de hidrogênio foram realizados em triplicata de reatores em batelada. Para avaliar a influência da concentração inicial de ácido acético como fonte de carbono na produção de hidrogênio, os reatores foram suplementados com ácido acético nas concentrações $10 \mathrm{mmol} / \mathrm{L}$ e $17 \mathrm{mmol} / \mathrm{L}$. Para verificar a influência da biomassa inicial, foram realizados ensaios em batelada utilizando-se inóculo nas concentrações de $0,02 \mathrm{~g} / \mathrm{L}$ e $0,04 \mathrm{~g} / \mathrm{L}$. Ensaios em batelada também foram realizados a fim de se verificar a influência da luminosidade na produção de hidrogênio, sendo os reatores mantidos sob intensidade luminosa de 9000 a 10.000 lux, 4000 a 5000 lux, ou mantidos no escuro.

Para verificar o comportamento da comunidade microbiana nos reatores em batelada foram realizados, ao longo do tempo, exames de microscopia óptica de contraste de fase, além do acompanhamento temporal, por cromatografia gasosa, do consumo de ácido acético e 
produção de gás hidrogênio. O crescimento celular foi verificado por meio da leitura de absorbância (660 nm) e do cálculo de massa seca utilizando-se a curva-padrão de crescimento. Determinou-se a velocidade específica de crescimento $(\mu)$ e tempo de geração da cultura, de acordo com Vareshe (1997). A caracterização da diversidade microbiana da cultura purificada de bactéria fototrófica púrpura não-sulfurosa foi realizada por meio da técnica do PCR/DGGE.

Ensaio de caracterização nutricional foi realizado em batelada, com a finalidade de se avaliar o crescimento e a produção de hidrogênio da cultura purificada, na presença de diferentes substratos orgânicos, na concentração de $20 \mathrm{mmol} / \mathrm{L}$ cada, como acetato de sódio, benzoato de sódio, butirato de sódio, citrato de sódio, etanol, fenol, frutose, glicose, glutamato de sódio, lactato de sódio, metanol, piruvato de sódio, propionato de sódio e succinato de sódio. Nestes ensaios, foram realizadas análises de crescimento celular, por meio da leitura de absorbância (660 nm) e cálculo de massa seca utilizando-se a curva-padrão de crescimento, e produção de gás hidrogênio por cromatografia gasosa, após 384 h de operação. Também foi realizado exame de microscopia óptica de contraste de fase para caracterização morfológica.

Todos os frascos foram mantidos, após inoculação da cultura, em câmara de germinação a $30 \pm 1{ }^{\circ} \mathrm{C}$. Para iluminação foram usadas lâmpadas fluorescentes de $20 \mathrm{~W}$, e a intensidade luminosa foi medida utilizando-se luxímetro. 


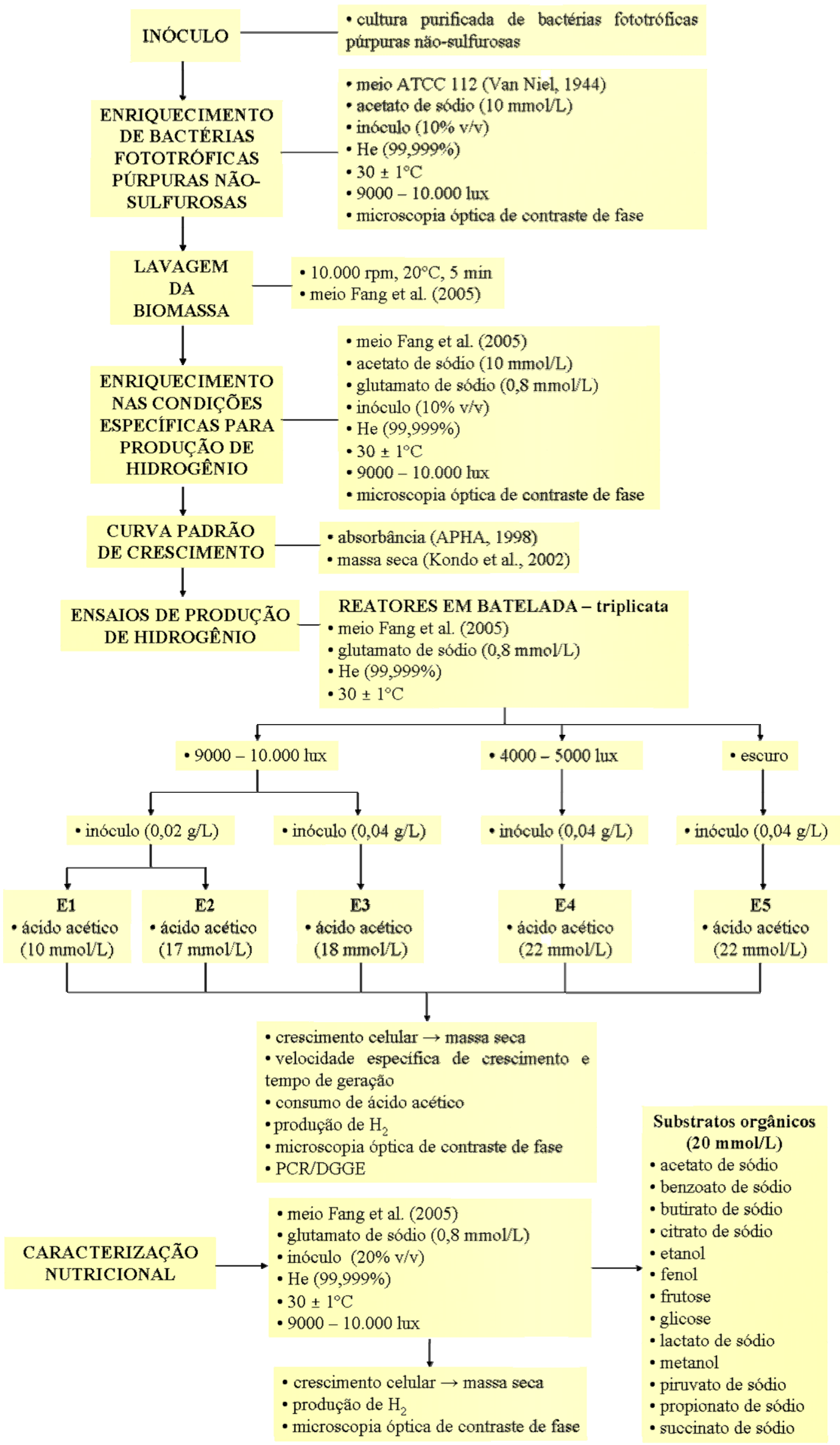

Figura 4.1. Fluxograma experimental 


\subsection{Composição e preparo do meio de cultura e soluções estoque}

\subsubsection{Meio de crescimento}

O meio utilizado para crescimento da cultura foi o meio ATCC 112 (VAN NIEL, 1944), o qual foi preparado pela dissolução dos componentes em água ultrapurificada, na ordem apresentada na Tabela 4.1. O pH foi ajustado a 7,0-7,2 com solução $1 \mathrm{~mol} / \mathrm{L}$ de hidróxido de sódio. Após esse procedimento, o meio foi mantido sob atmosfera de nitrogênio $(99,999 \%)$ durante 20 minutos. Ainda, sob fluxo desse gás, o meio foi distribuído em frascos de antibiótico de $100 \mathrm{~mL}$, com volume útil de $50 \mathrm{~mL}$. Então, os frascos foram fechados com tampas de butila, lacrados com selos de alumínio e esterilizados por autoclavação a $121^{\circ} \mathrm{C}$ e $1 \mathrm{~atm}$, por 20 minutos.

Tabela 4.1 - Composição do meio de cultura ATCC 112

\begin{tabular}{lc}
\hline \multicolumn{1}{c}{ Componentes } & $\begin{array}{c}\text { Quantidade }- \text { q.s.p. 1000 mL de água } \\
\text { ultrapurificada }\end{array}$ \\
\hline $\mathrm{K}_{2} \mathrm{HPO}_{4}$ & $1,0 \mathrm{~g}$ \\
$\mathrm{MgSO}_{4}$ & $0,5 \mathrm{~g}$ \\
Extrato de levedura & $10,0 \mathrm{~g}$ \\
\hline
\end{tabular}

Fonte: Van Niel (1944)

\subsubsection{Meio de cultura para produção de hidrogênio}

O meio utilizado nos ensaios de produção de hidrogênio foi preparado pela dissolução dos componentes em água ultrapurificada, de acordo com a ordem apresentada na Tabela 4.2. $\mathrm{O}$ pH foi ajustado a 7,0-7,2 com solução $1 \mathrm{~mol} / \mathrm{L}$ de hidróxido de sódio. Posteriormente, o meio foi esterilizado por filtração utilizando sistema Millipore e membrana 0,22 $\mu$ m, previamente esterilizados por autoclavação; depois distribuído em reatores, sob atmosfera de hélio $(99,999 \%)$. 
Tabela 4.2 - Composição do meio de cultura para produção de hidrogênio

\section{Componentes}

Quantidade -q.s.p. $1000 \mathrm{~mL}$ de água

ultrapurificada

\begin{tabular}{lc}
\hline $\mathrm{KH}_{2} \mathrm{PO}_{4}$ & $500 \mathrm{mg}$ \\
$\mathrm{MgSO}_{4} \cdot 7 \mathrm{H}_{2} \mathrm{O}$ & $400 \mathrm{mg}$ \\
$\mathrm{NaCl}$ & $400 \mathrm{mg}$ \\
$\mathrm{CaCl}_{2} \cdot 2 \mathrm{H}_{2} \mathrm{O}$ & $50 \mathrm{mg}$ \\
$\mathrm{Fe}(\mathrm{III})-$ citrato & $3,9 \mathrm{mg}$ \\
Solução traço de metais & $20 \mathrm{~mL}$ \\
Solução vitamina $\mathrm{B}_{12}$ & $1 \mathrm{~mL}$ \\
\hline
\end{tabular}

Fonte: Fang et al. (2005)

\subsubsection{Solução traço de metais}

A solução traço de metais, adicionada ao meio de cultura para produção de hidrogênio, foi preparada pela dissolução dos componentes em água ultrapurificada, de acordo com a ordem apresentada na Tabela 4.3. Após homogeneização da solução, introduziu-se, por 20 minutos, atmosfera de nitrogênio $(99,999 \%)$. Depois, a solução foi distribuída em frascos de antibiótico, também sob atmosfera de $\mathrm{N}_{2}$. Os frascos foram fechados, lacrados, esterilizados por autoclavação a $121^{\circ} \mathrm{C}$ e 1 atm por 20 minutos e, então, armazenados sob refrigeração.

Tabela 4.3 - Composição da solução traço de metais

\begin{tabular}{|c|c|}
\hline Componentes & $\begin{array}{c}\text { Quantidade -q.s.p. } 1000 \mathrm{~mL} \text { de água } \\
\text { ultrapurificada }\end{array}$ \\
\hline $\mathrm{H}_{3} \mathrm{BO}_{3}$ & $30 \mathrm{mg}$ \\
\hline $\mathrm{Na}_{2} \mathrm{MoO}_{4} \cdot 2 \mathrm{H}_{2} \mathrm{O}$ & $3 \mathrm{mg}$ \\
\hline $\mathrm{ZnSO}_{4} \cdot 7 \mathrm{H}_{2} \mathrm{O}$ & $10 \mathrm{mg}$ \\
\hline $\mathrm{CoCl}_{2} \cdot 6 \mathrm{H}_{2} \mathrm{O}$ & $20 \mathrm{mg}$ \\
\hline $\mathrm{CuCl}_{2} \cdot 2 \mathrm{H}_{2} \mathrm{O}$ & $1 \mathrm{mg}$ \\
\hline $\mathrm{MnCl}_{2} \cdot 4 \mathrm{H}_{2} \mathrm{O}$ & $3 \mathrm{mg}$ \\
\hline $\mathrm{NiCl}_{2} \cdot 6 \mathrm{H}_{2} \mathrm{O}$ & $2 \mathrm{mg}$ \\
\hline
\end{tabular}

Fonte: Fang et al. (2005) 


\subsubsection{Solução de vitamina $B_{12}$}

A solução estoque de vitamina $B_{12}$ foi preparada pela dissolução de $40 \mathrm{mg}$ desse reagente em 1000 mL de água ultrapurificada. Após homogeneização da solução, introduziuse, por 20 minutos, atmosfera de nitrogênio (99,999\%). Posteriormente, o meio foi esterilizado por filtração utilizando sistema Millipore e membrana 0,22 $\mu \mathrm{m}$, previamente esterilizados por autoclavação. A solução foi distribuída em frascos de antibiótico, sob fluxo de $\mathrm{N}_{2}$ e, então, armazenada sob refrigeração.

\subsubsection{Solução de acetato de sódio}

A solução estoque de acetato de sódio foi preparada através da dissolução de $41 \mathrm{~g}$ de acetato de sódio em $1000 \mathrm{~mL}$ de água ultrapurificada. Após homogeneização da solução, introduziu-se, por 10 minutos, atmosfera de nitrogênio $(99,999 \%)$. A solução foi distribuída em frascos de antibiótico, também sob fluxo de $\mathrm{N}_{2}$. Os frascos foram fechados, lacrados, esterilizados por autoclavação a $121^{\circ} \mathrm{C}$ e 1 atm por 20 minutos e, então, armazenados em temperatura ambiente.

\subsubsection{Solução de glutamato de sódio}

A solução estoque de glutamato de sódio foi preparada através da dissolução de $15,0 \mathrm{~g}$ de glutamato de sódio em $1000 \mathrm{~mL}$ de água ultrapurificada. Após a homogeneização da solução, introduziu-se, por 10 minutos, atmosfera de nitrogênio $(99,999 \%)$. A solução foi distribuída em frascos de antibiótico, sob atmosfera do mesmo gás. Os frascos foram fechados, lacrados, esterilizados por autoclavação a $121^{\circ} \mathrm{C}$ e 1 atm por 20 minutos e, então, armazenados em temperatura ambiente. 


\subsubsection{Soluções estoque dos substratos orgânicos}

As soluções estoque dos substratos orgânicos utilizados no ensaio de caracterização nutricional foram preparadas como descrito a seguir.

As soluções de benzoato de sódio, butirato de sódio, citrato de sódio, frutose, glicose, piruvato de sódio, propionato de sódio e succinato de sódio foram preparadas pela dissolução, separadamente, de 2,9 g; 2,2 g; 5,9 g; 3,6 g; 3,6 g; 2,2 g; 1,9 g e 5,4 g; respectivamente, dos compostos, em balões volumétricos de $100 \mathrm{~mL}$, completados com água ultrapurificada. Após homogeneização, as soluções foram distribuídas em frascos de antibiótico, sob atmosfera de $\mathrm{N}_{2}(99,999 \%)$. As soluções foram esterilizadas em autoclave e armazenadas em temperatura ambiente.

A solução de lactato de sódio foi preparada pela neutralização de 1,6 mL de ácido lático $(91 \%)$ com $0,8 \mathrm{~g}$ de hidróxido de sódio $(\mathrm{NaOH})$. Após essa reação, completou-se balão volumétrico de $100 \mathrm{~mL}$ com água ultrapurificada. Depois, a solução foi distribuída em frasco de antibiótico, sob atmosfera de $\mathrm{N}_{2}(99,999 \%)$, autoclavada e armazenada em temperatura ambiente.

A solução de fenol foi preparada pela adição de $1,9 \mathrm{~g}$ de fenol e $0,8 \mathrm{~g}$ de hidróxido de sódio $(\mathrm{NaOH})$, em balão volumétrico de $100 \mathrm{~mL}$, sendo o volume completado com água ultrapurificada. Posteriormente, a solução foi distribuída em frasco de antibiótico, sob atmosfera de $\mathrm{N}_{2}(99,999 \%)$, autoclavada e armazenada em temperatura ambiente.

As soluções de etanol e metanol foram preparadas adicionando-se $1,2 \mathrm{~mL}$ e $0,8 \mathrm{~mL}$ desses compostos, respectivamente, em balões volumétricos de $100 \mathrm{~mL}$, sendo o volume completado com água ultrapurificada. Após, as soluções foram armazenadas em temperatura ambiente. 


\subsection{Enriquecimento de bactérias fototróficas púrpuras não-sulfurosas}

O inóculo foi enriquecido em meio específico para bactérias fototróficas, meio ATCC 112, de acordo com Van Niel (1944), e acetato de sódio na concentração 10 mmol/L. Foram utilizados frascos de antibiótico de $100 \mathrm{~mL}$, com volume útil de $50 \mathrm{~mL}$. Após inoculação da cultura, na concentração de $10 \%(\mathrm{v} / \mathrm{v})$, os frascos foram incubados sob atmosfera de $\mathrm{He}$ (99,999\%), mantidos em câmara de germinação a $30 \pm 1^{\circ} \mathrm{C}$, sob iluminação de 9000 a 10.000 lux.

\subsection{Enriquecimento em condições específicas para produção de hidrogênio}

Após crescimento microbiano, foi realizada lavagem da biomassa, a fim de separar células viáveis de meio de cultura e restos celulares, centrifugando-a a $10.000 \mathrm{rpm}$ e $20^{\circ} \mathrm{C}$, durante 5 minutos. O sobrenadante foi então descartado e o pellet ressuspendido em meio específico segundo Fang et al. (2005).

Posteriormente à lavagem da biomassa, o inóculo foi enriquecido novamente, porém em condições específicas para produção de hidrogênio, com a finalidade de adaptar a cultura as novas condições de cultivo. Nesta etapa, foram utilizados frascos de Duran de $1000 \mathrm{~mL}$, com volume útil de $500 \mathrm{~mL}$, aos quais adicionou-se meio Fang et al. (2005), acetato de sódio (10 mmol/L), glutamato de sódio $(0,8 \mathrm{mmol} / \mathrm{L})$ e cultura previamente lavada $(10 \% \mathrm{v} / \mathrm{v})$. Os frascos foram, então, incubados sob atmosfera de He $(99,999 \%)$ e mantidos em câmara de germinação a $30 \pm 1^{\circ} \mathrm{C}$, sob iluminação de 9000 a 10.000 lux.

\subsection{Curva-padrão de crescimento}

Para medida de crescimento foi realizado ensaio para relacionar massa seca e densidade óptica $(660 \mathrm{~nm})$. Para tal, foram utilizados frascos de Duran de $5000 \mathrm{~mL}$, sendo $1000 \mathrm{~mL}$ de headspace preenchido com He (99,999\%), e $4000 \mathrm{~mL}$ de meio de reação 
(Figura 4.2), os quais foram preenchidos com meio de cultura específico (FANG et al., 2005), acetato de sódio $(10 \mathrm{mmol} / \mathrm{L})$, glutamato de sódio $(0,8 \mathrm{mmol} / \mathrm{L})$ e inóculo $(10 \% \mathrm{v} / \mathrm{v})$. Após inoculação da cultura, os frascos foram incubados sob atmosfera de He $(99,999 \%)$, mantidos em câmara de germinação a $30 \pm 1^{\circ} \mathrm{C}$, sob iluminação de 9000 a 10.000 lux. A cada 24 horas, foram retiradas amostras para análise de absorbância, de acordo com Standard Methods for Examination of Water and Wastewater (1998), e de massa seca, segundo metodologia adaptada de Kondo et al. (2002). Para esta última análise, foram retirados $45 \mathrm{~mL}$ de amostra, a qual foi centrifugada $\left(20^{\circ} \mathrm{C} ; 10.000 \mathrm{rpm} ; 5 \mathrm{~min}\right)$; posteriormente, o sobrenadante foi descartado e o pellet ressuspendido em água destilada. Então, este foi transferido para cápsulas de porcelana calcinadas e, previamente pesadas, as quais foram mantidas em estufa a $110^{\circ} \mathrm{C}$, até seu peso tornar-se constante.

A obtenção desta curva padrão de crescimento deveu-se à restrição de volume a ser retirado dos reatores nos ensaios de produção de hidrogênio. Sendo assim, a medida de crescimento foi obtida por meio da densidade óptica em espectrofotômetro a $660 \mathrm{~nm} \mathrm{e}$, utilizando-se a curva padrão, obteve-se a massa seca em g/L.

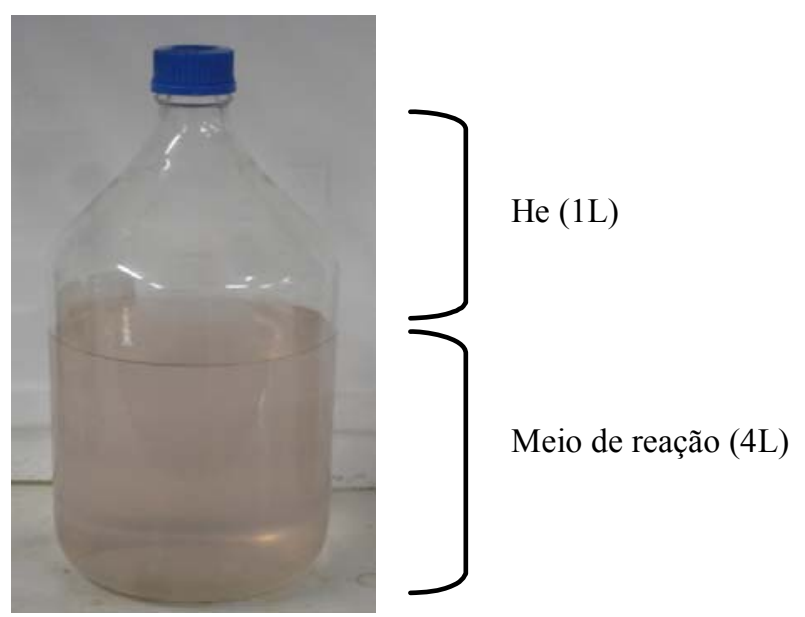

Figura 4.2. Reator em batelada (5000 mL) 


\subsection{Ensaios de produção de hidrogênio}

Os ensaios de produção de hidrogênio foram realizados em reatores em batelada, em triplicata, de acordo com a Tabela 4.4. Foram utilizados frascos de Duran de $2000 \mathrm{~mL}$, sendo $1000 \mathrm{~mL}$ de headspace preenchido com He $(99,999 \%)$, e $1000 \mathrm{~mL}$ de meio de reação (Figura 4.3).

Tabela 4.4 - Composição dos reatores anaeróbios utilizados nos ensaios de produção de hidrogênio

\begin{tabular}{|c|c|c|c|c|c|c|}
\hline Ensaio & $\begin{array}{l}\text { Meio de } \\
\text { cultura }\end{array}$ & $\begin{array}{c}\text { Ácido } \\
\text { acético } \\
\text { (mmol/L) }\end{array}$ & $\begin{array}{c}\text { Glutamato } \\
\text { de sódio } \\
(\mathrm{mmol} / \mathrm{L})\end{array}$ & $\begin{array}{c}\text { Biomassa } \\
\text { inicial } \\
(\mathrm{g} / \mathrm{L})\end{array}$ & $\begin{array}{c}\text { Temperatura } \\
\left({ }^{\circ} \mathrm{C}\right)\end{array}$ & $\begin{array}{c}\text { Iluminação } \\
\text { (lux) }\end{array}$ \\
\hline 1 & $\begin{array}{c}\text { Fang et al. } \\
(2005)\end{array}$ & 10 & 0,8 & 0,02 & $30 \pm 1$ & $\begin{array}{l}9000 \mathrm{a} \\
10.000\end{array}$ \\
\hline 2 & $\begin{array}{c}\text { Fang et al. } \\
(2005)\end{array}$ & 17 & 0,8 & 0,02 & $30 \pm 1$ & $\begin{array}{l}9000 \mathrm{a} \\
10.000\end{array}$ \\
\hline 3 & $\begin{array}{c}\text { Fang et al. } \\
(2005)\end{array}$ & 18 & 0,8 & 0,04 & $30 \pm 1$ & $\begin{array}{l}9000 \mathrm{a} \\
10.000\end{array}$ \\
\hline 4 & $\begin{array}{c}\text { Fang et al. } \\
(2005)\end{array}$ & 22 & 0,8 & 0,04 & $30 \pm 1$ & $\begin{array}{c}4000 \mathrm{a} \\
5000\end{array}$ \\
\hline 5 & $\begin{array}{c}\text { Fang et al. } \\
\text { (2005) }\end{array}$ & 22 & 0,8 & 0,04 & $30 \pm 1$ & $\begin{array}{c}\text { Ausência } \\
\text { de luz }\end{array}$ \\
\hline
\end{tabular}

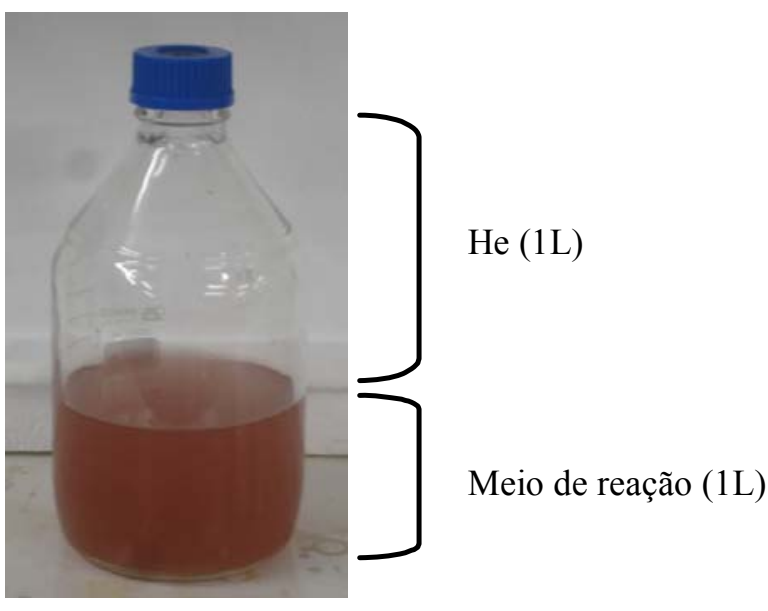

Figura 4.3. Reator anaeróbio em batelada 
Para avaliar a influência da concentração inicial de ácido acético como fonte de carbono na produção de hidrogênio, os reatores foram alimentados com as seguintes condições: meio de cultura específico (FANG et al., 2005), glutamato de sódio $(0,8 \mathrm{mmol} / \mathrm{L})$ como fonte de nitrogênio, inóculo $(0,02 \mathrm{~g} / \mathrm{L})$, e ácido acético $(10 \mathrm{mmol} / \mathrm{L}$ e $17 \mathrm{mmol} / \mathrm{L}$, separadamente). Após inoculação da cultura, os frascos foram incubados sob atmosfera de $\mathrm{He}$ (99,999\%) e mantidos em câmara de germinação a $30 \pm 1^{\circ} \mathrm{C}$, sob iluminação de 9000 a 10.000 lux.

Para verificar a influência da biomassa inicial na produção de hidrogênio, foram realizados ensaios em batelada utilizando-se as seguintes condições: meio Fang et al. (2005), glutamato de sódio $(0,8 \mathrm{mmol} / \mathrm{L})$, ácido acético $(18 \mathrm{mmol} / \mathrm{L})$, e inóculo nas concentrações de 0,02 g/L e 0,04 g/L. Após inoculação da cultura, os frascos foram incubados sob atmosfera de He $(99,999 \%)$ e mantidos em câmara de germinação a $30 \pm 1{ }^{\circ} \mathrm{C}$, sob iluminação de 9000 a 10.000 lux.

Ensaios em batelada também foram realizados a fim de se verificar a influência da intensidade luminosa na produção de hidrogênio. Os reatores foram preenchidos com meio Fang et al. (2005), glutamato de sódio (0,8 mmol/L), ácido acético (22 mmol/L) e inóculo na concentração $0,04 \mathrm{~g} / \mathrm{L}$. Após inoculação da cultura, os frascos foram incubados sob atmosfera de He $(99,999 \%)$ e mantidos em câmara de germinação a $30 \pm 1^{\circ} \mathrm{C}$, sob iluminação de 9000 a 10.000 lux, 4000 a 5000 lux, ou na ausência de luz.

\subsection{Determinação da velocidade específica de crescimento e tempo de geração}

Para a quantificação celular foi adotada leitura de absorbância. Para tal, 3,0 mL de amostra foram retiradas de maneira asséptica, colocadas em tubos Falcon estéreis e centrifugadas a $10.000 \mathrm{rpm}$ e $20^{\circ} \mathrm{C}$ durante 5 minutos. $\mathrm{O}$ sobrenadante foi descartado, o pellet ressuspendido em água destilada e, então, submetido à leitura de absorbância a 660 nm, em 
espectrofotômetro. Posteriormente, a medida de absorbância (660 nm) obtida foi introduzida na curva-padrão de crescimento, obtendo-se, assim, a massa seca celular (g/L).

A determinação da velocidade específica na fase exponencial de crescimento $(\mu)$ foi feita graficamente. Neste método, projetaram-se os valores do logaritmo neperiano (ln) da concentração celular versus o tempo de cultivo, e identificaram-se os pontos que possuíam a maior probabilidade de alinharem-se numa mesma reta. Estes pontos correspondem à fase exponencial de crescimento, na qual a velocidade é máxima e constante (VARESCHE, 1997). Por meio do cálculo da regressão linear dos pares de pontos, determinou-se a equação da reta, cujo coeficiente angular correspondeu ao valor de $\mu$.

Estabelecida a fase exponencial de crescimento, e a partir do cálculo da velocidade específica de crescimento $(\mu)$, foi possível calcular o tempo de geração da cultura $(\mathrm{Tg})$, a partir da seguinte equação:

$$
\operatorname{Tg}=\ln 2 / \mu
$$

\subsection{Caracterização nutricional}

A caracterização do crescimento microbiano e da produção de hidrogênio da cultura purificada, na presença de diferentes substratos orgânicos, foi realizada em batelada, em triplicatas de reatores. Foram utilizados frascos de antibiótico de $100 \mathrm{~mL}$, sendo $50 \mathrm{~mL}$ de headspace preenchido com He (99,999\%), e $50 \mathrm{~mL}$ de meio de reação. Estes frascos foram preenchidos com meio de cultura específico (FANG et al., 2005), glutamato de sódio $(0,8 \mathrm{mmol} / \mathrm{L})$ como fonte de nitrogênio, inóculo $(20 \% \mathrm{v} / \mathrm{v})$ e, como fonte de carbono, diversos substratos orgânicos, na concentração de $20 \mathrm{mmol} / \mathrm{L}$, como acetato de sódio, benzoato de sódio, butirato de sódio, citrato de sódio, etanol, fenol, frutose, glicose, lactato de sódio, metanol, piruvato de sódio, propionato de sódio e succinato de sódio. Também foi realizado ensaio sem fonte de carbono, apenas com glutamato de sódio $(0,8 \mathrm{mmol} / \mathrm{L})$ como substrato. 
Após inoculação da cultura, os frascos de antibiótico foram incubados sob atmosfera de $\mathrm{He}$ $(99,999 \%)$ e mantidos em câmara de germinação a $30 \pm 1^{\circ} \mathrm{C}$, sob iluminação de 9000 a 10.000 lux.

\subsection{Análises cromatográficas}

\subsubsection{Determinação de hidrogênio}

A concentração de hidrogênio produzido foi avaliada por meio da retirada de $0,1 \mathrm{~mL}$ de amostra da fase gasosa, utilizando seringa "gas tight" com trava. A análise foi realizada em cromatógrafo gasoso GC-2010 SHIMADZU, equipado com detector de condutividade térmica. A coluna utilizada foi a Carboxen 1010 plot $30 \mathrm{~m}$ x 0,53 mm, sendo o gás de arraste argônio sob fluxo de $21,9 \mathrm{~cm} / \mathrm{s}$. As temperaturas do forno, da coluna e do detector foram $30^{\circ} \mathrm{C}, 200^{\circ} \mathrm{C}$ e $230^{\circ} \mathrm{C}$, respectivamente.

Para o cálculo da concentração de gás hidrogênio $\left(\mathrm{mL}\right.$ de $\left.\mathrm{H}_{2} / \mathrm{L}\right)$ foi preparada curva analítica (calibração) do hidrogênio (ANEXO 1). Os valores das áreas de hidrogênio obtidos foram convertidos, por meio da curva-padrão, a $\mathrm{mL}$ de $\mathrm{H}_{2}$ nas CNTP. Durante todo o experimento, os frascos não foram despressurizados, a fim de se manter concentrações acumuladas do gás.

Os dados experimentais foram ajustados a sigmóide de Boltzmann (Equação 2) por meio do software Microcal Origin ${ }^{\circledR} 6.0$, minimizando a somatória dos erros ao quadrado. A sigmóide ajustada foi posteriormente derivada, utilizando mesmo software, a fim de se determinar as velocidades máximas de produção de hidrogênio.

$$
Y=\frac{A_{1}-A_{2}}{1+\mathrm{e}^{(x-x o) / d_{\mathrm{x}}}}+A_{2}
$$




\subsubsection{Determinação de ácido acético}

A concentração de ácido acético foi determinada por cromatografia gasosa, de acordo com metodologia desenvolvida por Moraes et al. (2000). A cada 24 horas foram retirados $2 \mathrm{~mL}$ de amostra dos reatores, sendo adicionado a estas $10 \mu \mathrm{L}$ de solução $\mathrm{NaOH}(2 \mathrm{~mol} / \mathrm{L})$, e congeladas em tubos de ensaio para posterior análise.

$\mathrm{Na}$ ocasião da análise, as amostras foram descongeladas, e adicionou-se aos tubos de ensaio $1,0 \mathrm{~g}$ de $\mathrm{NaCl}$ sólido, $100 \mu \mathrm{L}$ de solução $\mathrm{H}_{2} \mathrm{SO}_{4}(1 \mathrm{~mol} / \mathrm{L}), 100 \mu \mathrm{L}$ de solução de ácido crotônico $(700 \mathrm{mg} / \mathrm{L})$ e $0,60 \mathrm{~mL}$ de éter etílico. Os frascos foram tampados, agitados em Vortex por $30 \mathrm{~s}$, centrifugados a $2500 \mathrm{rpm}$ por $30 \mathrm{~s}$, e armazenados em congelador para posterior injeção no cromatógrafo.

Utilizou-se cromatógrafo Hewlett-packard, modelo CG, HP 6890, com coluna HP INNOWAX de comprimento $30 \mathrm{~m}$ e diâmetro interno $25 \mu \mathrm{m}$. O gás de arraste usado foi o hidrogênio, com vazão de $30 \mathrm{~mL} / \mathrm{min}$ e detector de ionização de chama. O aparelho foi operado sob as seguintes condições: temperatura do detector $300^{\circ} \mathrm{C}$ e do injetor $250^{\circ} \mathrm{C}-\mathrm{a}$ coluna foi aquecida a $100^{\circ} \mathrm{C}$ por 3 minutos e em seguida aplicou-se gradiente de temperatura (rampa de aquecimento) de $5^{\circ} \mathrm{C} / \mathrm{min}$ até atingir $180^{\circ} \mathrm{C}$; fluxo de ar $300 \mathrm{~mL} / \mathrm{min}$. O limite de detecção do ácido acético no método utilizado foi de $5,13 \mathrm{mg} / \mathrm{L}$. O volume injetado foi de $1 \mu \mathrm{L}$, utilizando-se seringa SGE de $10 \mu \mathrm{L}$.

\subsection{Análise da intensidade luminosa}

Para iluminação foram usadas lâmpadas fluorescentes de $20 \mathrm{~W}$, sendo utilizadas quatro lâmpadas nos ensaios mantidos sob intensidade luminosa de 9000 a 10.000 lux, duas lâmpadas nos ensaios de 4000 a 5000 lux, e nenhuma lâmpada quando os ensaios foram realizados na ausência de luz. A cada novo ensaio, realizava-se a reposição de lâmpadas novas. A intensidade luminosa foi medida em vários pontos da câmara de germinação, 
utilizando-se luxímetro Testo, modelo 545. Este era colocado próximo aos reatores com o sensor de leitura voltado para as lâmpadas. No momento da leitura de intensidade luminosa a câmara era fechada e procedia-se a leitura.

\subsection{Análise da diversidade microbiana}

\subsubsection{Exames microscópicos}

As características morfológicas do inóculo e da comunidade microbiana presente nos ensaios de enriquecimento e de produção de hidrogênio foram observadas através de microscopia óptica de contraste de fase, utilizando microscópio Leica DMLB, com sistema de captura de imagem Optronics e software Image Pro-Plus. Também foi realizada coloração de Gram, segundo metodologia da Scientific Services of Cultures Collections da Alemanha (DSM, 1991) para diferenciação dos microrganismos em Gram positivos ou Gram negativos.

\subsubsection{Análise de biologia molecular}

A avaliação da diversidade microbiana foi realizada através da técnica de reação de polimerização em cadeia (PCR) do gene do RNAr 16S, seguida da eletroforese em gel com gradiente desnaturante (DGGE). O DNA foi extraído segundo protocolo de Griffiths et al. (2000). Na amplificação dos fragmentos do RNAr 16S foram utilizados primers específicos do Domínio Bacteria (NIELSEN et al., 1999). Os fragmentos de RNAr 16S amplificados foram separados pela eletroforese em gel de gradiente desnaturante (DGGE). A Tabela 4.5 descreve os primers do domínio Bacteria utilizados nas análises de PCR/DGGE. 
Tabela 4.5 - Primers utilizados nas análises de PCR/DGGE

\begin{tabular}{lll}
\hline Microrganismos & \multicolumn{1}{c}{ Primers e seqüência (5' - 3') } & \multicolumn{1}{c}{$\begin{array}{c}\text { Referência } \\
\text { Bibliográfica }\end{array}$} \\
\hline Domínio Bacteria & 968 FGC (5' - AAC CGC GAA GAA CCT & Nielsen et al. (1999) \\
& TAC - 3') \\
& 1392 R (5' - AACG GGC GGT GTG TAC - & \\
& 3') & \\
GC clamp (5'- CGC CCG CCG GGG CGC & \\
& CCG GGC GGG GCG GGG GCA CGG \\
& GGGG - 3')
\end{tabular}

A partir do DNA extraído da amostra foram obtidos fragmentos do RNAr 16S, utilizando a técnica da amplificação, através da reação de polimerização em cadeia (PCR) com primers homólogos às regiões conservadas do gene RNAr $16 \mathrm{~S}$. Na reação de amplificação foram usadas as seguintes soluções: $0,5 \mu \mathrm{L}$ de Taq DNA polymerase $(5 \mathrm{U} / \mu \mathrm{L}) ; 5$ $\mu \mathrm{L}$ de tampão PCR 10X; $1,5 \mu \mathrm{L}$ de $\mathrm{MgCl}_{2}(50 \mathrm{mmol} / \mathrm{L}) ; 5 \mu \mathrm{L}$ de dNTP $(2 \mathrm{mmol} / \mathrm{L}) ; 0,5 \mu \mathrm{L}$ de "primer forward" (100 pmol/L); 0,5 $\mu \mathrm{L}$ do "primer reverse" (100 pmol/L) e $2 \mu \mathrm{L}$ de DNA extraído. O aparelho utilizado nessa técnica foi o termociclador "Gene Amp. PCR System 2400" (Perkin-Elmer Cetus, Norwalk, Conn). As condições usadas na programação do aparelho para amplificação do fragmento do RNAr 16S estão descritas na Tabela 4.6.

Tabela 4.6 - Programação do termociclador para amplificação dos fragmentos do RNAr 16S

\begin{tabular}{c|c|c|c|c|c|c|c}
\hline Microrganismos & $\begin{array}{c}\mathbf{N}^{\mathbf{0}} \mathbf{d e} \\
\text { ciclos }\end{array}$ & $\begin{array}{c}\text { Desnaturação } \\
\text { Inicial }\end{array}$ & Desnaturação & Anelamento & Extensão & $\begin{array}{c}\text { Extensão } \\
\text { Final }\end{array}$ & Resfriamento \\
\hline Domínio & 35 & $94^{\circ} \mathrm{C}$ & $94^{\circ} \mathrm{C}$ & $38^{\circ} \mathrm{C}$ & $72^{\circ} \mathrm{C}$ & $72^{\circ} \mathrm{C}$ & $4^{\circ} \mathrm{C}$ \\
Bacteria & & $5 \mathrm{~min}$ & $1,30 \mathrm{~min}$ & $45 \mathrm{~s}$ & $1 \mathrm{~min}$ & $5 \mathrm{~min}$ & \\
\hline
\end{tabular}

O procedimento para realização do DGGE consistiu na preparação da solução do gel na concentração de $30 \%$ e $70 \%$ do gel de gradiente desnaturante (gel acrilamida - 40\%; solução 50X de TAE - Tris Ácido Acético EDTA; formamida e uréia), para o Domínio Bacteria. O gel foi preparado com $111 \mu \mathrm{L}$ de APS (perssulfato de amônia - 10\%); $11 \mu \mathrm{L}$ de temed (tetrametiletilenodiamina). Após a solidificação do gel $(1 \mathrm{~h})$, as placas contendo o gel 
foram colocadas em suporte apropriado e transferido para cuba de DGGE. Nesta cuba foram adicionados 7 L de água destilada e $140 \mathrm{~mL}$ de TAE 50X. A temperatura de "corrida" do gel foi constante $\left(65^{\circ} \mathrm{C}\right)$, voltagem de 175 Volts, com duração de $16 \mathrm{~h}$. O gel foi retirado da cuba e corado com solução de coloração (TAE 1 x contendo $1 \mu \mathrm{g} / \mathrm{mL}$ de brometo de etídeo) por 20 minutos e depois transferido para o fotodocumentador Eagle Eye TM III (Stratagene) acoplado ao computador e software Eagle Slight UV para visualização das bandas, sob exposição à UV de $254 \mathrm{~nm}$. 


\section{RESULTADOS E DISCUSSÃO}

\subsection{Ensaios de enriquecimento}

A microscopia óptica de contraste de fase do inóculo mostrou a predominância de bactérias no formato de bacilos retos (Figura 5.1a). Após enriquecimento nas condições específicas para produção de hidrogênio, houve predominância de células no formato de bacilos curvos e aparecimento de aglomerados no formato de rosetas (Figura 5.1b). De acordo com Bergey`s Manual of Systematic Bacteriology (1989), este aglomerado é típico de alguns gêneros de bactérias fototróficas púrpuras não-sulfurosas, onde células individuais ligam-se umas as outras através de seus flagelos polares. O seqüenciamento de amostras do inóculo de bactérias fototróficas anoxigênicas provenientes da sub-superfície de lagoa anaeróbia, utilizando primers pufM.750R e pufM.557F, mostrou $92 \%$ de similaridade com Rhodopseudomonas palustris (Saavedra et al., 2005).

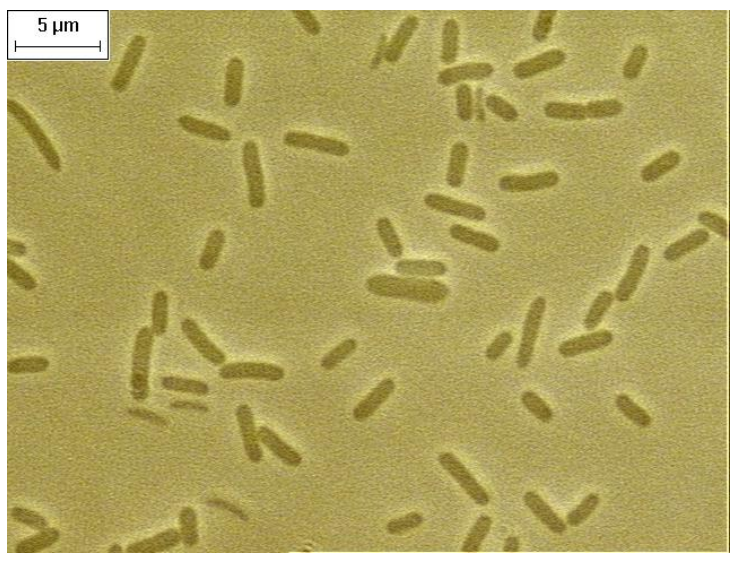

(a)

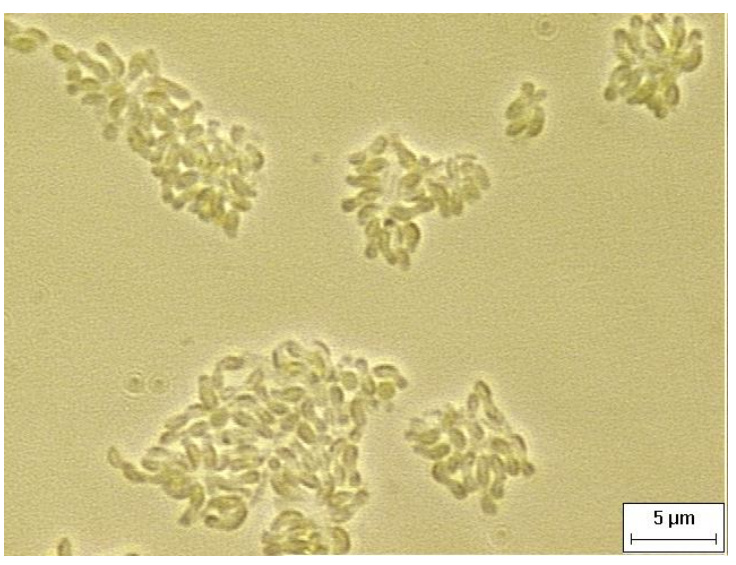

(b)

Figura 5.1. Microscopia óptica de contraste de fase das seguintes amostras: (a) inóculo e (b) reatores em batelada de enriquecimento

A técnica de coloração de Gram realizada em amostras do inóculo e da comunidade microbiana presente nos ensaios de enriquecimento revelou a predominância de 
microrganismos Gram-negativos (Figura 5.2). Todos os gêneros de bactérias fototróficas púrpuras não-sulfurosas são Gram-negativos (BERGEY, 1989).
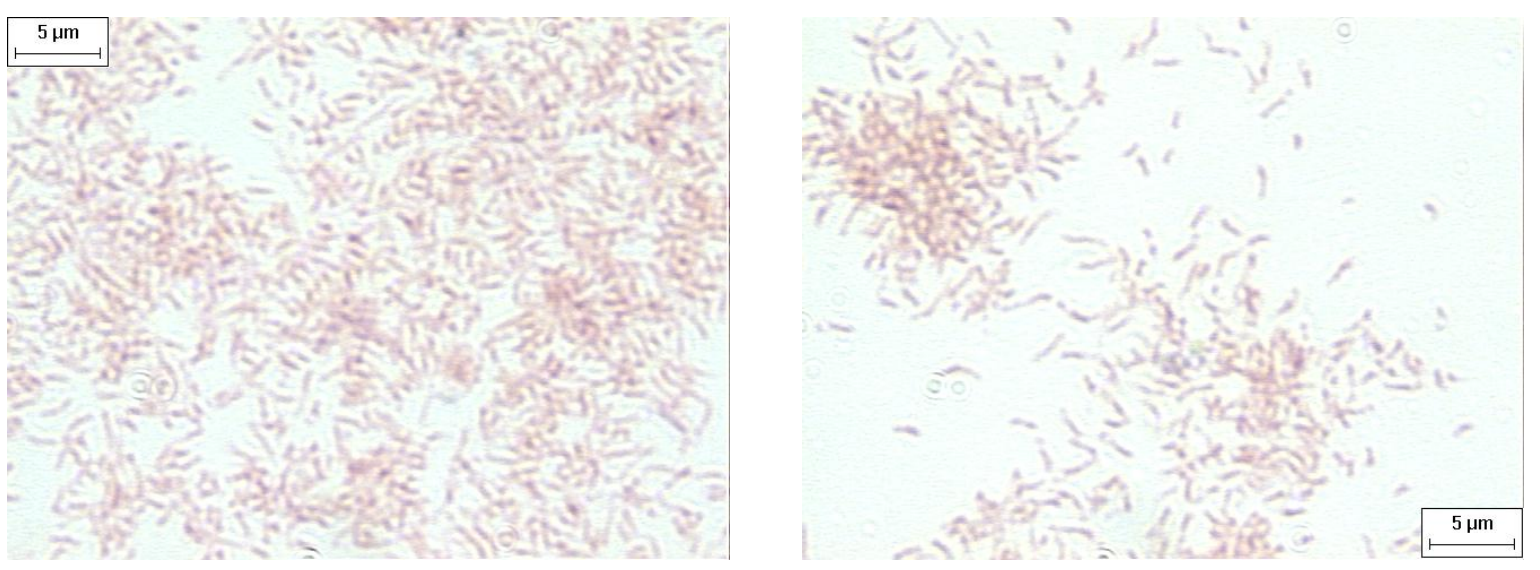

Figura 5.2. Bacilos curvos Gram-negativos em microscopia óptica de luz comum

\subsection{Curva-padrão de crescimento}

A massa seca celular (MSC, g/L) da cultura purificada de bactéria fototrófica púrpura não-sulfurosa utilizada neste trabalho foi proporcional à absorbância a $660 \mathrm{~nm}\left(A_{660}\right)$ e pôde ser calculada de acordo com a seguinte relação:

$\mathrm{MSC}_{\text {bactéria fototrófica }}=0,66 \mathrm{~A}_{660}$

A curva-padrão de crescimento é mostrada na Figura 5.3, e os valores de crescimento estão apresentados no APÊNDICE 1.

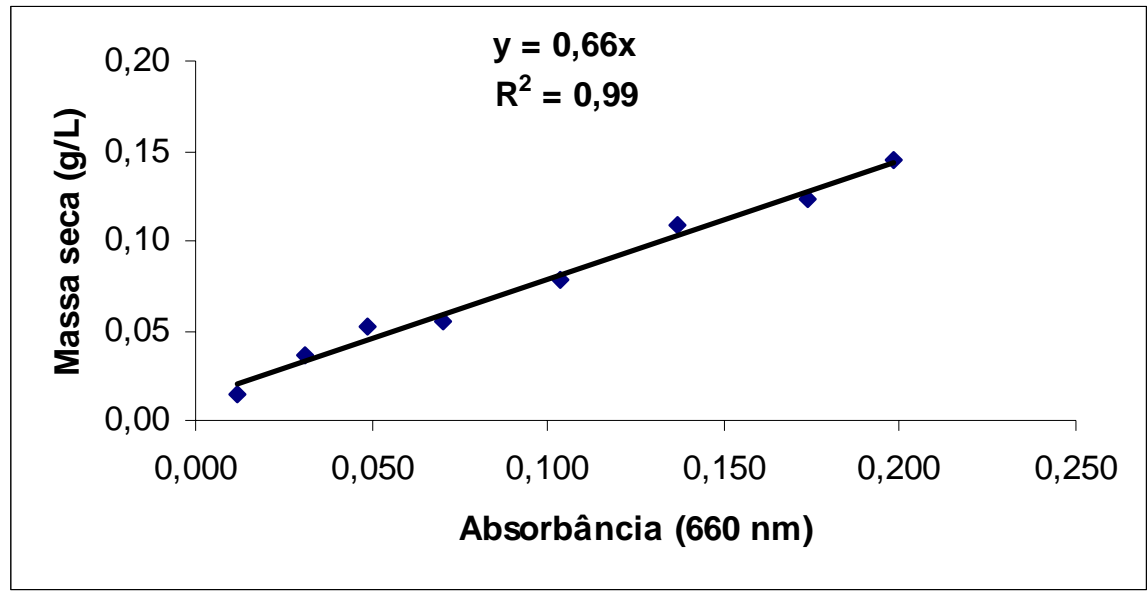

Figura 5.3. Curva-padrão de crescimento de bactéria fototrófica púrpura não-sulfurosa 


\subsection{Ensaios de produção de hidrogênio}

Os ensaios de produção de hidrogênio tiveram duração aproximada de 408 horas. Os valores de massa seca, produção de hidrogênio acumulado e consumo de ácido acético estão apresentados nos APÊNDICES 2, 3 e 4, respectivamente.

O ácido acético foi escolhido como fonte de carbono por ter sido a fonte utilizada por Saavedra et al. (2005) nas condições de purificação da cultura, e também por ser um dos principais produtos do processo de fermentação anaeróbia. O efeito da concentração inicial de ácido acético no crescimento celular é mostrado na Figura 5.4. Comparando-se as curvas de crescimento dos ensaios onde se utilizou $10 \mathrm{mmol} / \mathrm{L}$ e $17 \mathrm{mmol} / \mathrm{L}$ de concentração inicial de ácido acético, pode-se notar que ambas apresentaram-se muito semelhantes, com fase lag até 100 h, e início da fase estacionária após 250 h de experimento. Entretanto, após 200 h os reatores alimentados com $17 \mathrm{mmol} / \mathrm{L}$ de acético passaram a apresentar concentração de biomassa ligeiramente mais elevada $(0,18 \mathrm{~g} / \mathrm{L}$ massa seca) em relação àqueles alimentados com $10 \mathrm{mmol} / \mathrm{L}$ do mesmo ácido $(0,15 \mathrm{~g} / \mathrm{L}$ massa seca). Isto deve ter ocorrido porque, após a fase de adaptação da cultura, provavelmente, a maior quantidade de substrato $(17 \mathrm{mmol} / \mathrm{L})$ favoreceu o crescimento celular.

Velocidades específicas de crescimento $(\mu)$ de $0,0084 \mathrm{~h}^{-1}$ e $0,01 \mathrm{~h}^{-1}$, e tempos de geração (Tg) de 82,5 h e 69,3 h foram obtidos para as culturas crescidas nos ensaios com $10 \mathrm{mmol} / \mathrm{L}$ e $17 \mathrm{mmol} / \mathrm{L}$ de ácido acético (APÊNDICE 5), respectivamente.

Os resultados evidenciaram, também, que em ambos os ensaios não houve consumo total do ácido acético, sendo que no ensaio com menor concentração $(10 \mathrm{mmol} / \mathrm{L})$ ocorreu consumo máximo de $78 \%$ em 384 h. Todavia, no ensaio com maior concentração (17 mmol/L) foi verificado consumo máximo de 51\%, também em $384 \mathrm{~h}$ de experimento (Figura 5.4). 
Najafpour et al. (2004) utilizaram bactéria fototrófica Rhodospirillum rubrum em culturas em batelada para produção de hidrogênio, e observaram que, para concentração inicial de acetato de $37 \mathrm{mmol} / \mathrm{L}$, ocorreu ligeira utilização da fonte orgânica, enquanto que para concentrações menores $(13-24 \mathrm{mmol} / \mathrm{L})$ o consumo foi significativamente mais elevado. Fang et al. (2005) trabalharam com cultura mista fototrófica e acetato a várias concentrações, e observaram que a eficiência de degradação do acetato diminuiu com o aumento da concentração inicial de 10 a $21 \mathrm{mmol} / \mathrm{L}$, sendo que 99,4 e 96,3\% de acetato foram consumidos, respectivamente. Todavia, para concentração inicial de $49 \mathrm{mmol} / \mathrm{L}$ ocorreu consumo de somente $76,5 \%$. No presente trabalho, a eficiência de consumo do ácido acético também apresentou decréscimo de 78 para 51\%, quando a concentração inicial foi elevada de $10 \mathrm{mmol} / \mathrm{L}$ para $17 \mathrm{mmol} / \mathrm{L}$.

Com relação à produção de hidrogênio, as respostas da cultura a diferentes concentrações de ácido acético (10 mmol/L e $17 \mathrm{mmol} / \mathrm{L})$ foram semelhantes (Figura 5.5). Tanto no ensaio com $10 \mathrm{mmol} / \mathrm{L}$ de ácido acético, como com $17 \mathrm{mmol} / \mathrm{L}$, a produção de hidrogênio apresentou fase lag de aproximadamente 100 h, e início da fase estacionária após 280 h. Como mencionado anteriormente, o mesmo ocorreu com o crescimento celular indicando, provavelmente, que ambos podem estar estreitamente relacionados.

As máximas produções alcançadas nos ensaios com $10 \mathrm{mmol} / \mathrm{L}$ e $17 \mathrm{mmol} / \mathrm{L}$ de ácido acético foram $8,3 \mathrm{~mL} \mathrm{H}_{2} / \mathrm{g}$ massa seca.h e $8,8 \mathrm{~mL} \mathrm{H}_{2} / \mathrm{g}$ massa seca.h, respectivamente. Barbosa et al. (2001) obtiveram 14 mL $\mathrm{H}_{2} / \mathrm{g}$ massa seca.h com Rhodopseudomonas palustris, como máxima produção de hidrogênio, em ensaios em batelada com $16 \mathrm{mmol} / \mathrm{L}$ de acetato de sódio. Sasikala et al. (1991) atingiram produção máxima de $7,2 \mathrm{~mL} \mathrm{H} / \mathrm{g}$ massa seca.h, utilizando bactéria fototrófica Rhodobacter sphaeroides e $21 \mathrm{mmol} / \mathrm{L}$ de malato, em reatores em batelada. 


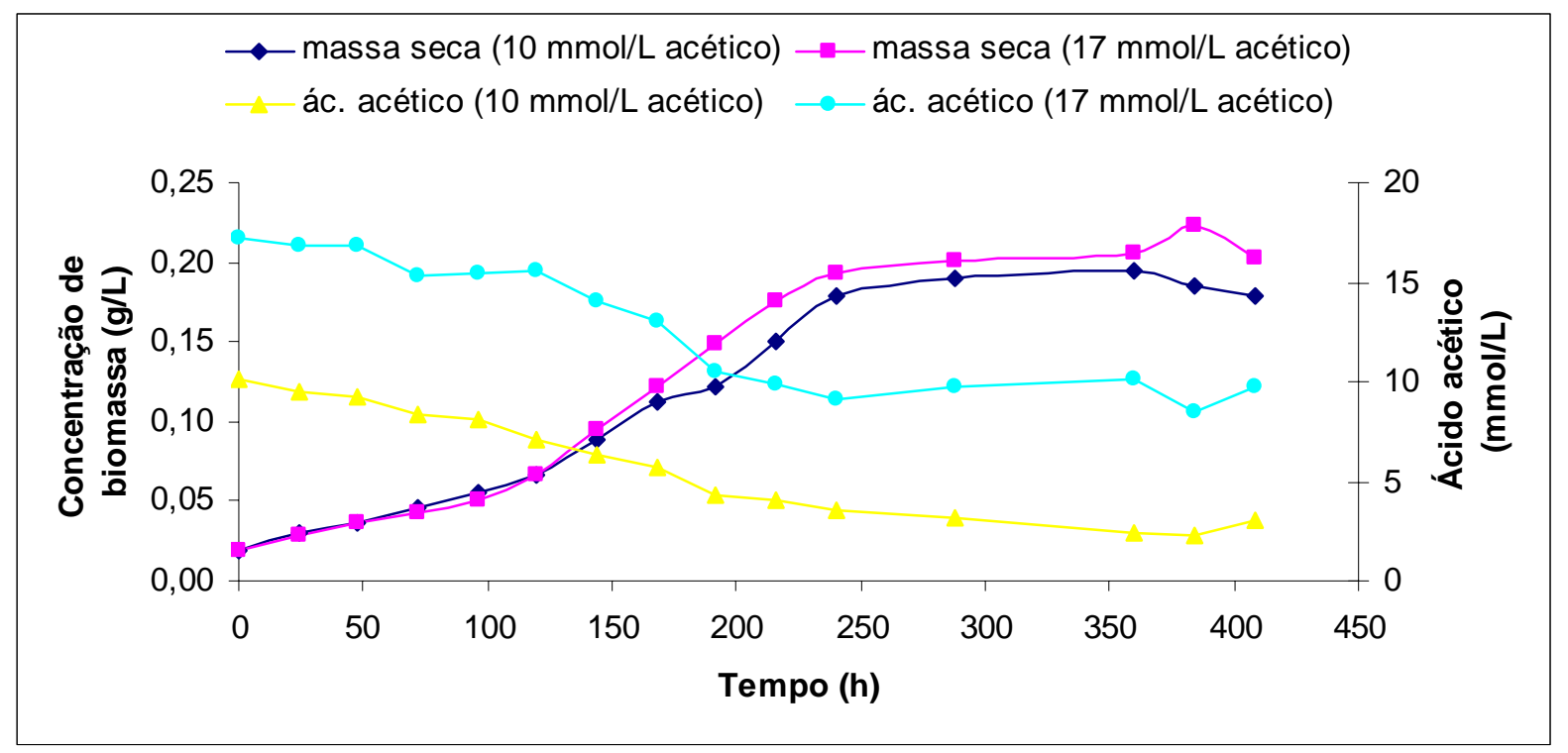

Figura 5.4. Crescimento celular e consumo de ácido acético da cultura de bactérias fototróficas púrpuras não-sulfurosas em reatores em batelada

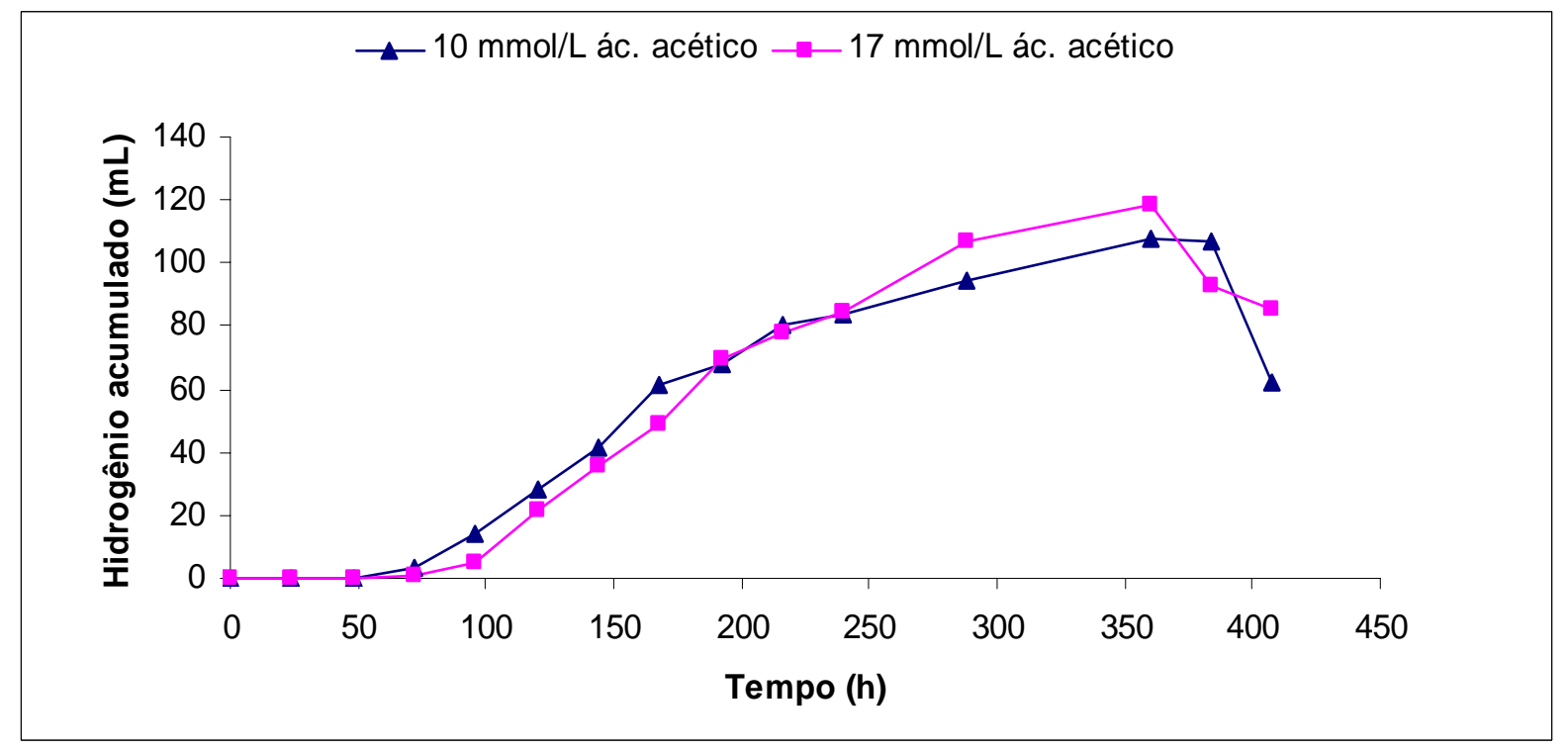

Figura 5.5. Produção de hidrogênio para diferentes concentrações de ácido acético da cultura de bactérias fototróficas púrpuras não-sulfurosas em reatores em batelada

Eroglu et al. (1999) investigaram a produção de hidrogênio utilizando cultura fototrófica Rhodobacter sphaeroides em fotobiorreator de coluna. Os autores observaram que o tempo necessário para início da produção de hidrogênio variou de 40 a 80 horas, e que existiu uma relação entre concentração celular e velocidade de produção de hidrogênio. Ainda, segundo os autores, o volume de gás hidrogênio produzido, a duração de produção de 
hidrogênio e a máxima concentração celular aumentaram com a concentração de malato. Barbosa et al. (2001) observaram diminuição do hidrogênio produzido, de 214 para 27 mL H2 por frasco, quando a concentração de acetato foi reduzida de 22 para $6 \mathrm{mmol} / \mathrm{L}$. Para concentrações de 6 a $11 \mathrm{mmol} / \mathrm{L}$ de acetato ocorreu limitação na produção de hidrogênio, aproximadamente $50 \mathrm{~h}$ após inoculação. Foi constatado por Fang et al. (2005) aumento da produção de hidrogênio com o aumento da concentração de acetato de 10 a $50 \mathrm{mmol} / \mathrm{L}$ em cultura mista fototrófica. Também segundo os autores, a fase lag de produção de hidrogênio não foi afetada pela concentração inicial de acetato. Nath et al. (2005) também observaram que o aumento da concentração de acetato de 6 para $42 \mathrm{mmol} / \mathrm{L}$ resultou em subseqüente aumento na produção de hidrogênio. No presente trabalho, o aumento da concentração inicial de ácido acético de 10 para $17 \mathrm{mmol} / \mathrm{L}$, não favoreceu aumento significante na concentração de biomassa $(0,15$ e $0,18 \mathrm{~g} / \mathrm{L}$ massa seca, respectivamente), e na velocidade máxima de produção de hidrogênio ( 8,3 e $8,8 \mathrm{~mL} \mathrm{H}_{2} / \mathrm{g}$ massa seca.h, respectivamente).

Também foram realizados ensaios em batelada com a finalidade de se verificar a influência da concentração inicial de biomassa na produção de hidrogênio. Nestes ensaios foi utilizado inóculo nas concentrações de $0,02 \mathrm{~g} / \mathrm{L}$ e $0,04 \mathrm{~g} / \mathrm{L}$ da cultura de bactéria fototrófica púrpura não sulfurosa. A Figura 5.6 mostra a influência das diferentes concentrações iniciais de biomassa no crescimento celular. Verificou-se que os ensaios com diferentes concentrações iniciais de inóculo apresentaram o mesmo padrão de crescimento. Entretanto, no ensaio com maior concentração de biomassa $(0,04 \mathrm{~g} / \mathrm{L})$ a fase lag durou aproximadamente $24 \mathrm{~h}$, enquanto que no ensaio de menor concentração $(0,02 \mathrm{~g} / \mathrm{L})$, esta fase teve duração aproximada de 100 h. Em ambos os ensaios, a fase estacionária iniciou-se após 250 h.

Velocidades específicas de crescimento $(\mu)$ de $0,01 \mathrm{~h}^{-1}$ e $0,0082 \mathrm{~h}^{-1}$, e tempos de geração (Tg) de 69,3 h e 84,5 h foram obtidos para as culturas crescidas nos ensaios com 0,02 g/L e 0,04 g/L de biomassa inicial, respectivamente (APÊNDICE 5). 
O consumo de ácido acético nos ensaios com diferentes concentrações de biomassa inicial $(0,02 \mathrm{~g} / \mathrm{L}$ e $0,04 \mathrm{~g} / \mathrm{L})$ é apresentado na Figura 5.6. Os resultados mostraram que, assim como nos ensaios anteriores, não houve consumo total, sendo que para a concentração de biomassa de 0,02 g/L ocorreu 51\% de consumo máximo em 384 h. Por outro lado, no ensaio com maior concentração $(0,04$ g/L) ocorreu $70 \%$ de utilização do substrato orgânico em 408 h de experimento.

Em relação à produção de hidrogênio (Figura 5.7), observou-se que no ensaio onde a concentração de biomassa inicial era maior $(0,04 \mathrm{~g} / \mathrm{L})$, ocorreu diminuição da fase lag de 100 para $50 \mathrm{~h}$, quando comparado com aquele cuja biomassa foi de 0,02 g/L. A fase estacionária, em ambos os ensaios, iniciou-se aproximadamente após 280 h de experimento.

As produções máximas alcançadas nos ensaios com $0,02 \mathrm{~g} / \mathrm{L}$ e $0,04 \mathrm{~g} / \mathrm{L}$ de biomassa inicial foram $8,8 \mathrm{~mL} \mathrm{H}_{2} / \mathrm{g}$ massa seca.h e $10,6 \mathrm{~mL} \mathrm{H}_{2} / \mathrm{g}$ massa seca.h, respectivamente. 


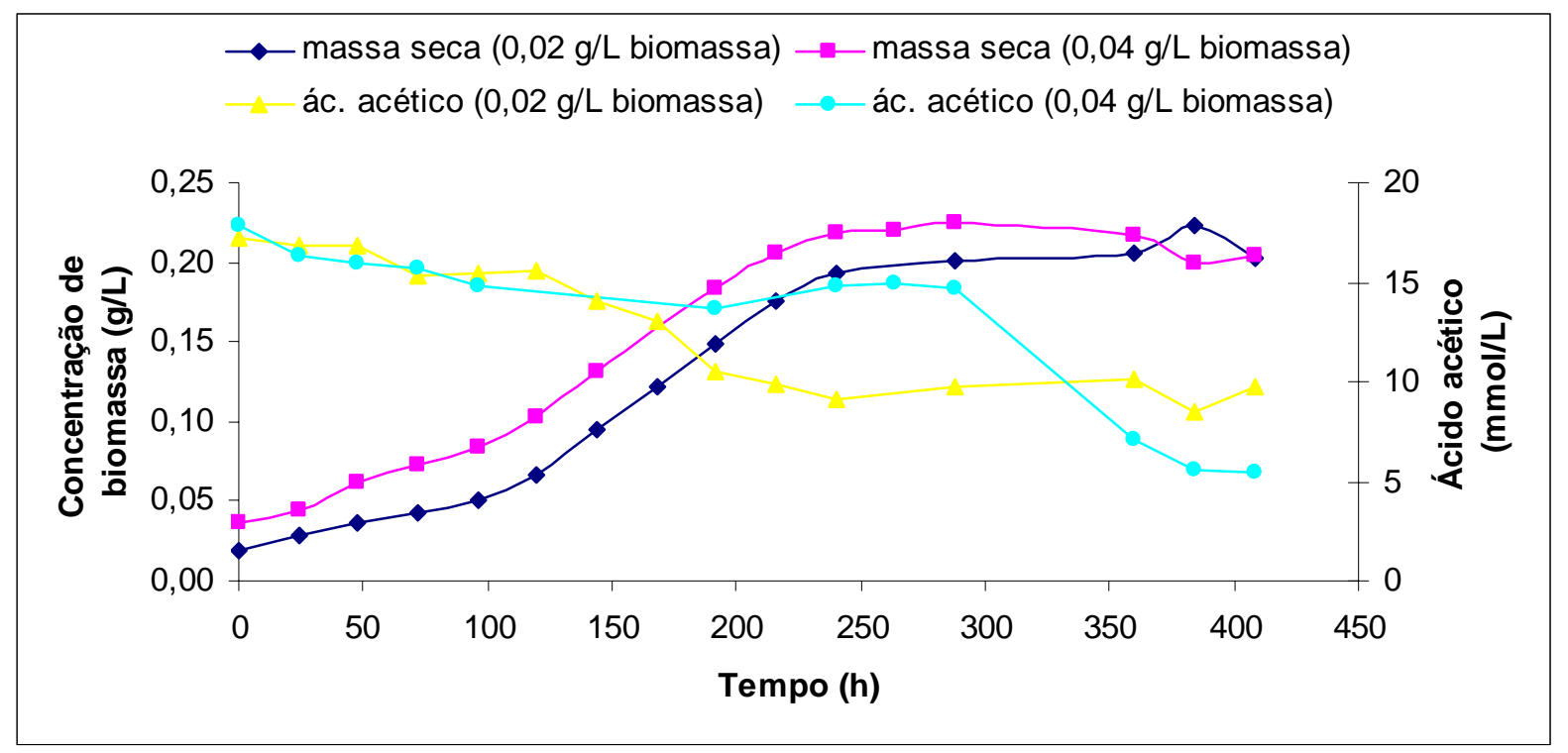

Figura 5.6. Crescimento celular e consumo de ácido acético para diferentes concentrações iniciais da cultura de bactérias fototróficas púrpuras não-sulfurosas em reatores em batelada

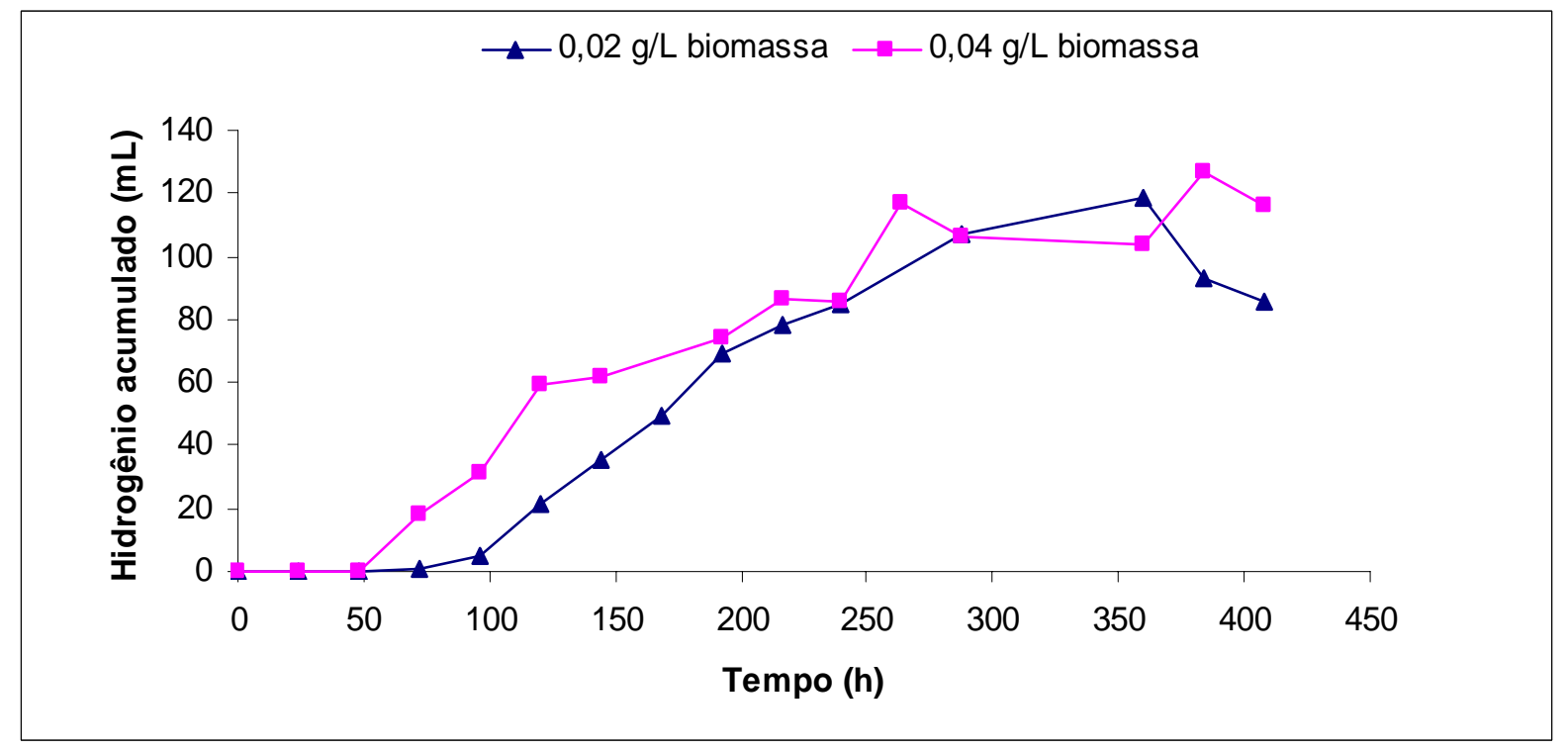

Figura 5.7. Produção de hidrogênio para diferentes concentrações iniciais da cultura de bactérias fototróficas púrpuras não-sulfurosas em reatores em batelada

Para verificar a influência da intensidade luminosa na produção de hidrogênio foram realizados ensaios em batelada, sob iluminação de 9000 a 10.000 lux, 4000 a 5000 lux, ou então com reatores mantidos na ausência de luz. O efeito da intensidade luminosa no crescimento celular é mostrado na Figura 5.8a. 
Comparando-se as curvas de crescimento dos ensaios sob diferentes intensidades luminosas, pode-se notar que aqueles mantidos sob iluminação de 9000 a 10.000 lux e 4000 a 5000 lux apresentaram padrão de crescimento muito semelhante, com fase lag de $24 \mathrm{~h}$. Porém, no ensaio mantido sob iluminação de 4000 a 5000 lux, a fase estacionária teve início após 190 h, enquanto que no ensaio de 9000 a 10.000 lux, essa fase iniciou-se após 250 h do início do experimento. Tais resultados sugeriram que maior intensidade luminosa favoreceu o crescimento celular. Os reatores mantidos na ausência de luz não apresentaram nenhum aumento de biomassa.

Velocidades específicas de crescimento $(\mu)$ de $0,0082 \mathrm{~h}^{-1}$ e $0,0088 \mathrm{~h}^{-1}$, e tempos de geração (Tg) de 84,5 h e 78,8 h foram obtidos para as culturas crescidas nos ensaios sob iluminação de 9000 a 10.000 lux e 4000 a 5000 lux, respectivamente (APÊNDICE 5).

A variação temporal do consumo de ácido acético nos ensaios sob diferentes intensidades luminosas está mostrado na Figura 5.8b. Os resultados mostraram que não houve consumo total de ácido acético, embora no ensaio com intensidade luminosa mais elevada (9000 - 10.000 lux) ocorreu consumo máximo de 70\% em 408 h. Todavia, no ensaio com menor intensidade de luz (4000 - 5000 lux) observou-se consumo máximo de 57\% em 288 h de experimento. No ensaio mantido no escuro praticamente não ocorreu consumo do substrato orgânico.

A produção de hidrogênio obtida para diferentes intensidades luminosas é mostrada na Figura 5.8c. Quando os reatores foram mantidos sob iluminação de 9000 a 10.000 lux, a produção de hidrogênio apresentou fase lag de até 50 h e início da fase estacionária após 280 h. Nos reatores mantidos sob iluminação de 4000 a 5000 lux, a fase lag durou até 72 h, e a fase estacionária iniciou-se somente após 340 h de experimento. Ainda, no ensaio onde a iluminação foi mais elevada (9000 a 10.000 lux), a produção de hidrogênio acumulado foi maior do que no ensaio com menor iluminação (4000 a 5000 lux). 

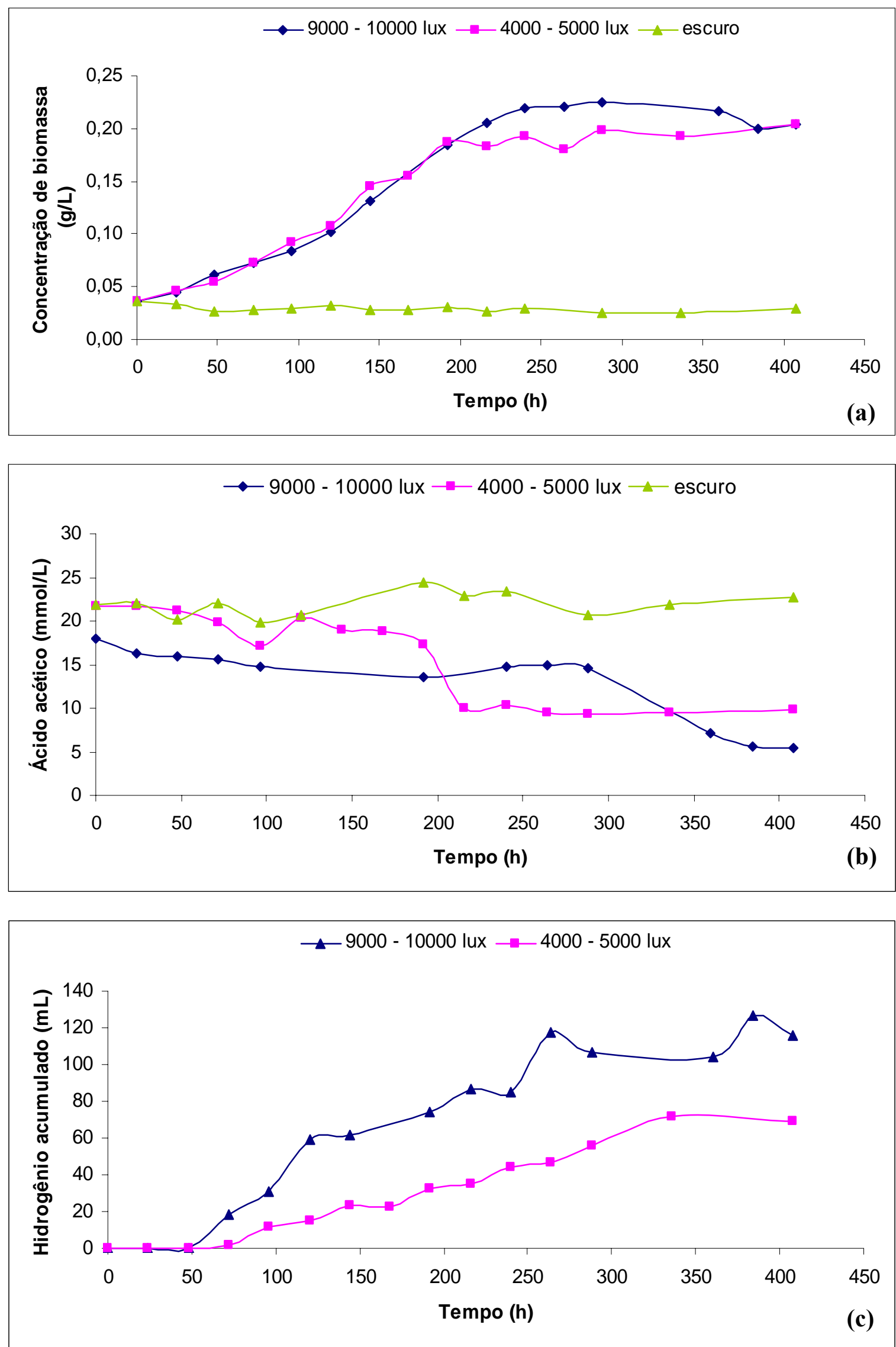

Figura 5.8. Efeito da intensidade luminosa no crescimento celular (a); no consumo de ácido acético (b) e na produção de hidrogênio (c) 
Como dito anteriormente, quando a cultura de bactérias fototróficas púrpuras nãosulfurosas foi mantida no escuro não houve crescimento celular. Nestas mesmas condições, a produção de hidrogênio foi nula.

A máxima produção alcançada no ensaio mantido sob iluminação de 9000 a 10.000 lux foi $10,6 \mathrm{~mL} \mathrm{H}_{2} / \mathrm{g}$ massa seca.h.

Os valores de hidrogênio acumulado obtido no ensaio sob iluminação de 4000 a 5000 lux não se ajustaram adequadamente a sigmóide de Boltzmann. Sendo assim, foi realizado ajuste linear, e a máxima produção de hidrogênio obtida neste ensaio foi 1,0 $\mathrm{mL} \mathrm{H}_{2} / \mathrm{g}$ massa seca.h. De acordo com os resultados, a diminuição na intensidade luminosa provocou proeminente redução na velocidade de produção de hidrogênio.

Nakada et al. (1995) estudaram a relação entre penetração de luz e produção de hidrogênio por cultura de bactéria fototrófica Rhodobacter sphaeroides. A intensidade de luz na superfície do reator foi mantida a 20.000 ou 40.000 lux e, segundo os autores, baixas intensidades luminosas (20.000 lux) não foram favoráveis à produção de hidrogênio por bactérias fototróficas. Segundo Kondo et al. (2002), a produção de hidrogênio por bactérias fototróficas é determinada preferencialmente pela uniformidade de luz no reator. No presente trabalho, baixas intensidades luminosas (4000 a 5000 lux) não foram favoráveis à produção de hidrogênio, enquanto que intensidades mais elevadas (9000 a 10.000 lux) mostraram resultados de produção de hidrogênio maiores, por bactérias fototróficas púrpuras nãosulfurosas.

Os valores das velocidades de produção de hidrogênio estão apresentados no APÊNDICE 6.

Os períodos da fase lag de crescimento e de produção de hidrogênio, a máxima concentração de biomassa alcançada, a velocidade específica de crescimento $(\mu)$, o tempo de 
geração (Tg) e a velocidade máxima de produção de hidrogênio para cada ensaio estão mostrados na Tabela 5.1.

Tabela 5.1 - Resultados obtidos nos ensaios de produção de hidrogênio

\begin{tabular}{ccccccc}
\hline Ensaio* $^{*}$ & $\begin{array}{c}\text { Fase lag } \\
\text { crescimento }\end{array}$ & $\begin{array}{c}\text { Máxima } \\
\text { concentração }\end{array}$ & $\begin{array}{c}\boldsymbol{\mu} \\
\left(\mathbf{h}^{-1}\right)\end{array}$ & $\begin{array}{c}\mathbf{T g} \\
(\mathbf{h})\end{array}$ & $\begin{array}{c}\text { Fase lag } \\
\text { produção }\end{array}$ & $\begin{array}{c}\text { Velocidade máxima } \\
\text { produção } \mathbf{H}_{2}\end{array}$ \\
& $\mathbf{( h )}$ & biomassa (g/L) & & & $\mathbf{H}_{\mathbf{2}}(\mathbf{h})$ & $\left(\mathbf{m L} \mathbf{H}_{2} / \mathbf{g}\right.$ massa seca.h) \\
\hline $\mathbf{1}$ & 100 & 0,19 & 0,0084 & 82,5 & 100 & 8,3 \\
$\mathbf{2}$ & 100 & 0,22 & 0,0100 & 69,3 & 100 & 8,8 \\
$\mathbf{3}$ & 24 & 0,23 & 0,0082 & 84,5 & 50 & 10,6 \\
$\mathbf{4}$ & 24 & 0,20 & 0,0088 & 78,8 & 72 & 1,00 \\
\hline
\end{tabular}

*ensaio 1: $10 \mathrm{mmol} / \mathrm{L}$ ácido acético; 0,02 g/L biomassa inicial; 9000 - 10.000 lux ensaio 2: $17 \mathrm{mmol} / \mathrm{L}$ ácido acético; 0,02 g/L biomassa inicial; $9000-10.000$ lux ensaio 3: $18 \mathrm{mmol} / \mathrm{L}$ ácido acético; $0,04 \mathrm{~g} / \mathrm{L}$ biomassa inicial; 9000 - 10.000 lux ensaio 4: $22 \mathrm{mmol} / \mathrm{L}$ ácido acético; 0,04 $\mathrm{g} / \mathrm{L}$ biomassa inicial; 4000 - 5000 lux

De acordo com os resultados obtidos, a máxima concentração de biomassa alcançada foi independente da concentração inicial de ácido acético ou de biomassa, variando de 0,19 a 0,23 g/L. Contudo, quando se utilizou maior concentração de biomassa $(0,04 \mathrm{~g} / \mathrm{L})$, o crescimento apresentou diminuição da fase lag de 100 para 24 h. As velocidades específicas de crescimento e tempos de geração pouco variaram entre os ensaios, mostrando, assim, não terem relação direta com as concentrações de ácido acético e biomassa.

A velocidade máxima de produção de hidrogênio pouco variou $(8,3$ a $8,8 \mathrm{~mL} \mathrm{H} / \mathrm{g}$ massa seca.h) com o aumento da concentração de ácido acético inicial de 10 para $17 \mathrm{mmol} / \mathrm{L}$. Porém, com o aumento da concentração de biomassa de 0,02 para $0,04 \mathrm{~g} / \mathrm{L}$ ocorreu aumento significativo na velocidade de produção de hidrogênio (8,8 para 10,6 $\mathrm{mL} \mathrm{H}_{2} / \mathrm{g}$ massa seca.h), assim como diminuição da fase lag de 100 para 50 h. A diminuição na intensidade luminosa de 9000 - 10.000 lux para 4000 - 5000 lux promoveu diminuição rigorosa na velocidade de produção de hidrogênio; ou seja, de 10,6 para 1,0 $\mathrm{mL} \mathrm{H}_{2} / \mathrm{g}$ massa seca.h. 
O ensaio realizado no escuro não apresentou crescimento celular, produção de hidrogênio e consumo de ácido acético. Tal fato deve ter ocorrido porque, embora bactérias fototróficas apresentem ampla diversidade metabólica, a cultura utilizada neste trabalho já estava adaptada à condição fototrófica de crescimento. Além disso, segundo Koku et al. (2002) bactérias fototróficas púrpuras não-sulfurosas exibem crescimento marginal e nenhuma produção de hidrogênio sob condições anaeróbias na ausência de luz.

\subsubsection{Exames microscópicos}

A microscopia óptica de contraste de fase da cultura nos ensaios alimentados com $10 \mathrm{mmol} / \mathrm{L}$ e $17 \mathrm{mmol} / \mathrm{L}$ de ácido acético apresentaram predominância de bacilos curvos, aglomerados em formações de roseta (Figura 5.9). Estes mesmos aglomerados, assim como os bacilos curvos, também foram predominantes nos ensaios com diferentes concentrações iniciais de biomassa (Figura 5.10). O mesmo ocorreu nos ensaios mantidos sob iluminação de 9000 a 10.000 lux e 4000 a 5000 lux (Figura 5.11). Já o ensaio mantido no escuro apresentou redução visível da concentração de biomassa celular, assim como aparecimento de células amorfas e debris celulares (Figura 5.12).

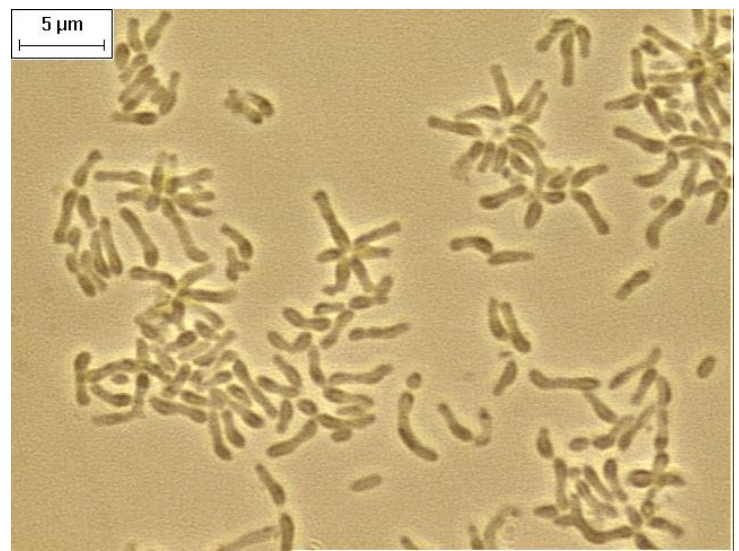

(a)

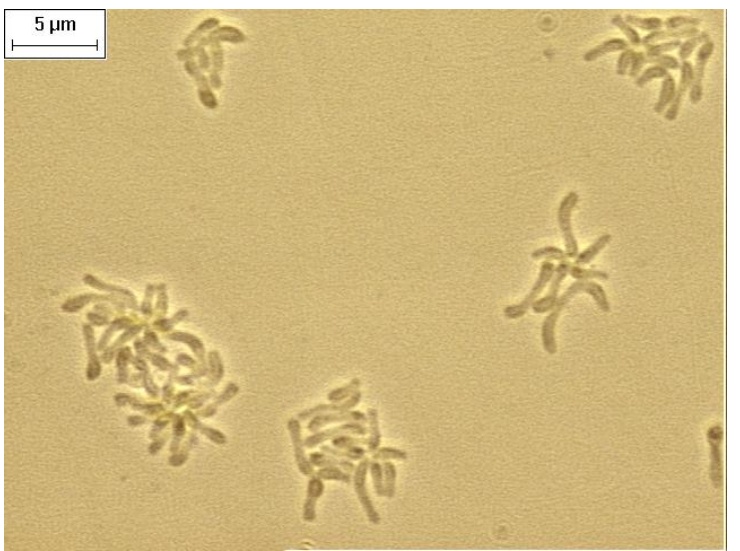

(b)

Figura 5.9. Microscopia óptica de contraste de fase das amostras dos reatores em batelada alimentados com ácido acético nas seguintes concentrações: (a) $10 \mathrm{mmol} / \mathrm{L}$ e (b) $17 \mathrm{mmol} / \mathrm{L}$ 


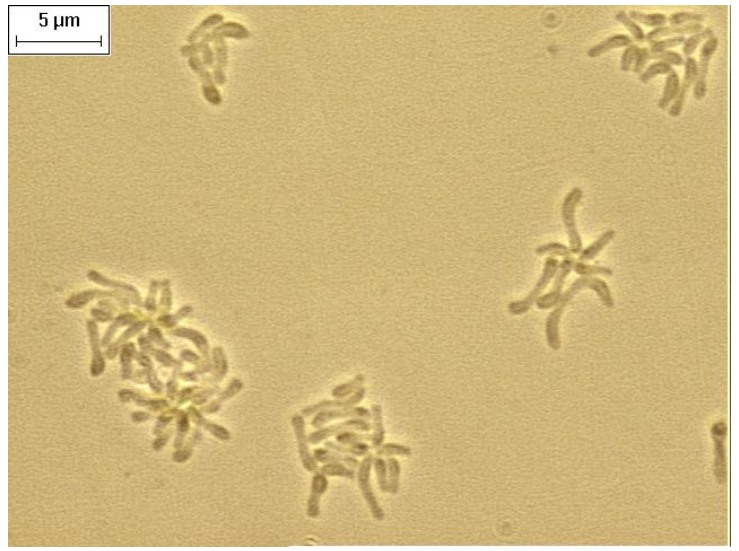

(a)

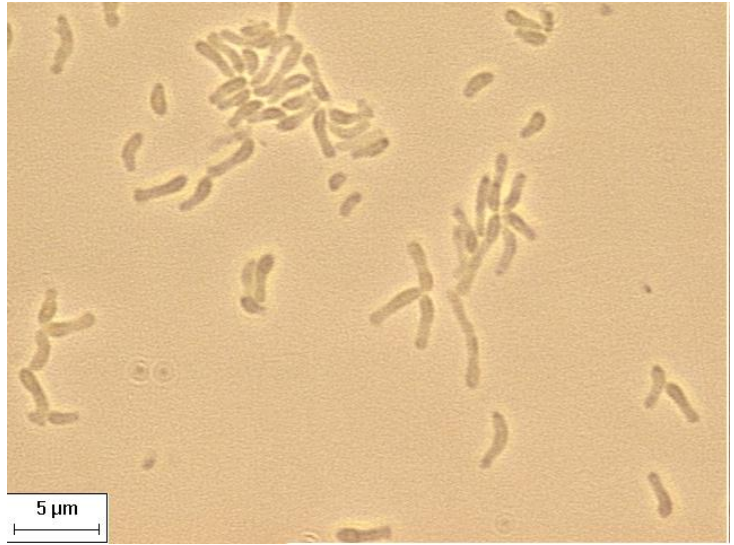

(b)

Figura 5.10. Microscopia óptica de contraste de fase das amostras dos reatores em batelada inoculados com as seguintes concentrações de biomassa: (a) $0,02 \mathrm{~g} / \mathrm{L}$ e (b) $0,04 \mathrm{~g} / \mathrm{L}$

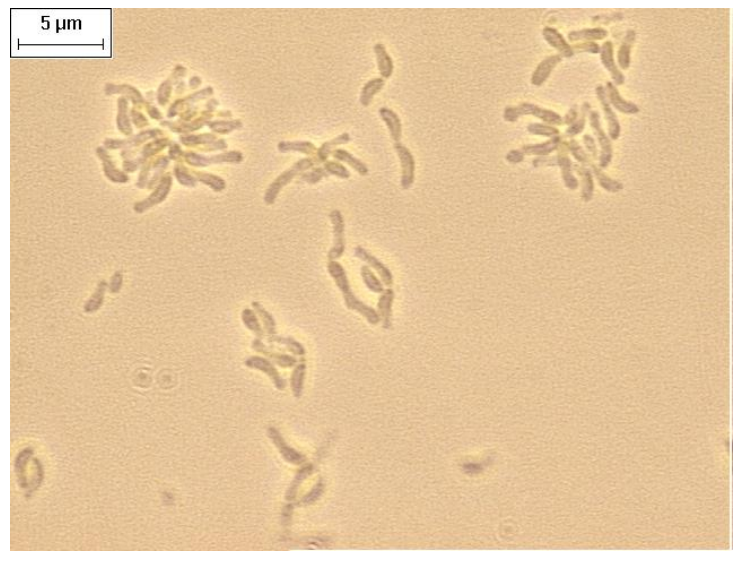

(a)

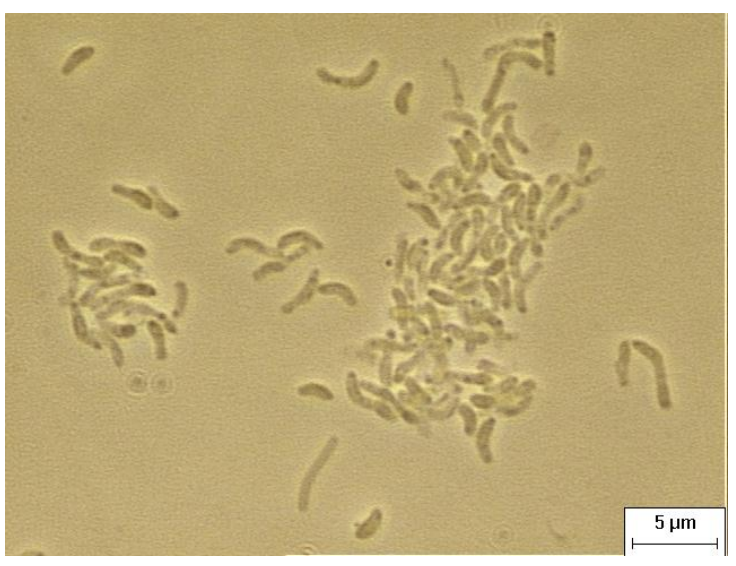

(b)

Figura 5.11. Microscopia óptica de contraste de fase das amostras dos reatores em batelada mantidos sob iluminação de: (a) 9000 a 10.000 lux e (b) 4000 a 5000 lux

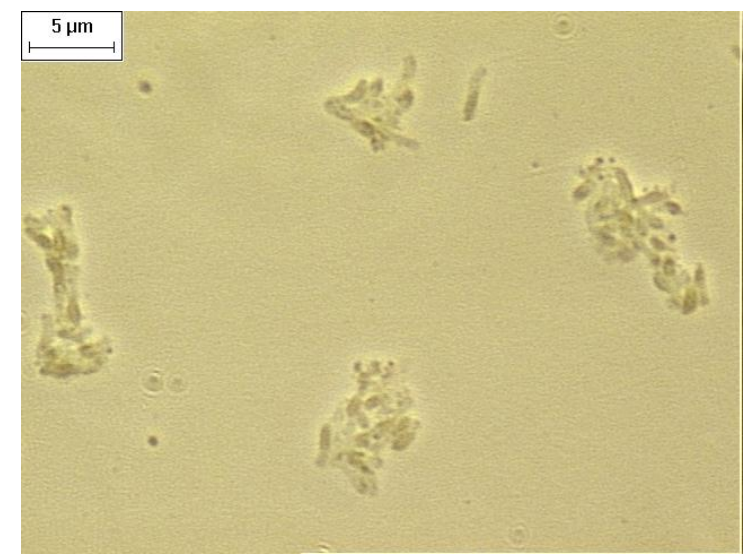

Figura 5.12. Microscopia óptica de contraste de fase das amostras dos reatores em batelada mantidos no escuro 


\subsubsection{Biologia molecular}

É importante ressaltar que, para a caracterização microbiana, as amostras foram coletadas na fase exponencial de crescimento. O objetivo dessa análise foi promover a comparação e a avaliação da cultura de bactérias fototróficas púrpuras não-sulfurosas, verificando possíveis alterações em função das diferentes concentrações iniciais de ácido acético e biomassa, e também devido a mudanças na intensidade luminosa fornecida.

Os resultados da análise do PCR/DGGE podem ser observados na Figura 5.13, que mostra o gel de DGGE das amostras dos ensaios de produção de hidrogênio. Assim, por meio da análise das bandas de DGGE para o domínio Bacteria e pelas letras de A a F, pode-se verificar elevada similaridade de bandas, ou seja, não houve variações relevantes na estrutura das populações microbianas. As populações representadas pelas bandas A, B e C foram favorecidas pelas condições nutricionais e ambientais adotadas, em relação a condição do inóculo. A população indicada pela banda D foi favorecida em todas as condições, inclusive no inóculo. Já a população representada pela banda $\mathrm{F}$ foi mais sensível quando mantida no escuro. Todavia, a população mostrada pela banda E foi favorecida somente na condição de ausência de luminosidade. 


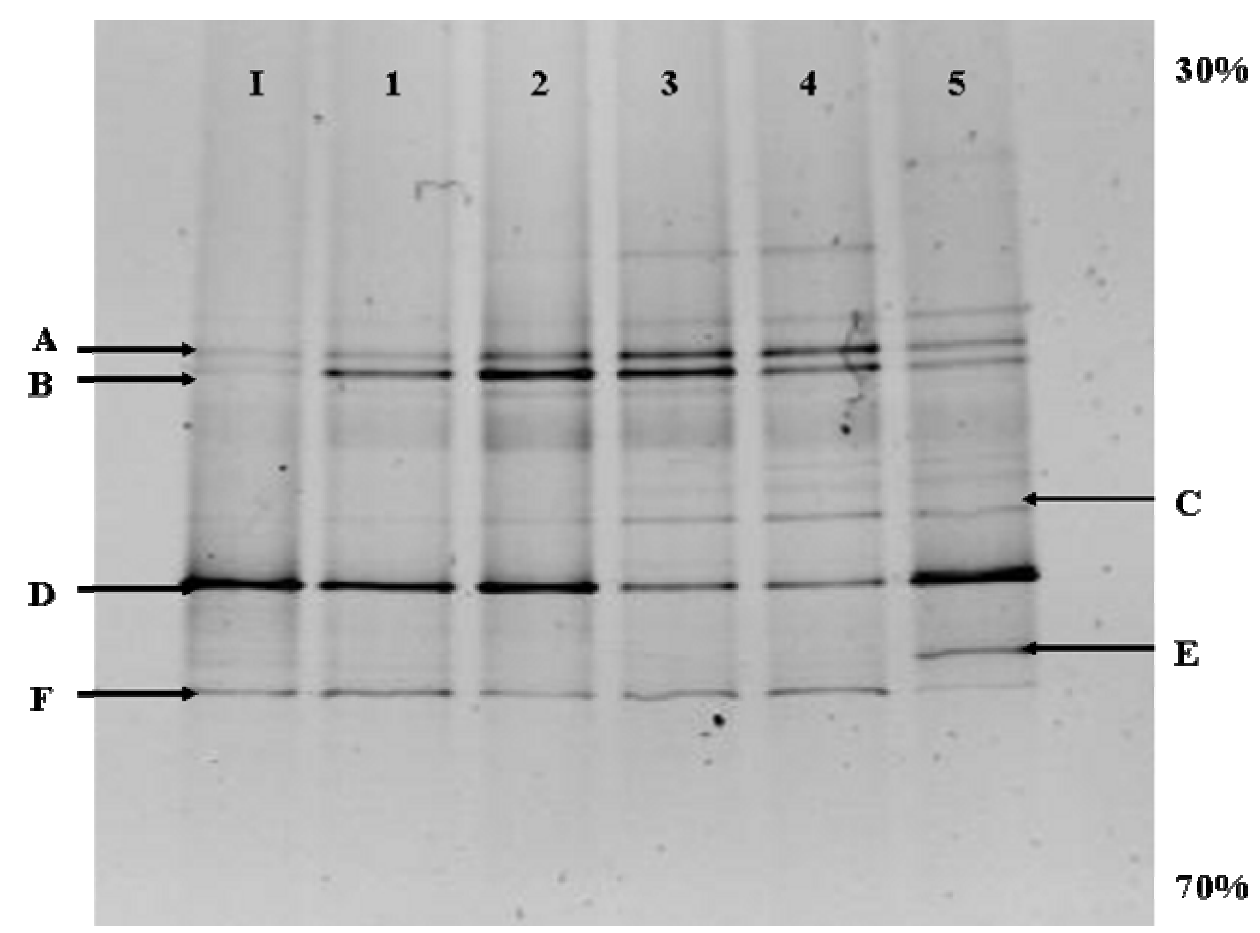

Figura 5.13. Resultados das análises de DGGE dos fragmentos dos produtos de PCR amplificados com primers do Domínio Bactéria para as amostras: I - inóculo; 1 - ensaio com $10 \mathrm{mmol} / \mathrm{L}$ de ácido acético; 2 - ensaio com $17 \mathrm{mmol} / \mathrm{L}$ de ácido acético; 3 - ensaio com 0,04 g/L biomassa; 4 - ensaio mantido sob iluminação de 4000 a 5000 lux; 5 - ensaio mantido no escuro

\subsection{Caracterização nutricional}

O ensaio de caracterização nutricional foi realizado com a finalidade de se avaliar o crescimento celular e produção de hidrogênio pela cultura purificada de bactérias fototróficas púrpuras não-sulfurosas, na presença de diversos substratos orgânicos. Este ensaio teve duração de 384 h, e os resultados obtidos estão apresentados no APÊNDICE 7.

Como controle de crescimento foi utilizado reator contendo acetato de sódio (20 $\mathrm{mmol} / \mathrm{L})$ e glutamato de sódio $(0,8 \mathrm{mmol} / \mathrm{L})$, por se tratar da condição utilizada nos ensaios anteriores. O valor inicial de biomassa deste frasco foi 0,020 g/L. Após 384 h, este ensaio controle apresentou concentração de biomassa de 0,250 g/L (Figura 5.14).

No ensaio de caracterização, a biomassa inicial dos frascos alimentados com diferentes fontes de carbono variou de 0,020 a $0,026 \mathrm{~g} / \mathrm{L}$ de massa seca. Após $384 \mathrm{~h}$ de experimento observou-se crescimento elevado em butirato de sódio $(0,114 \mathrm{~g} / \mathrm{L}$ massa seca), piruvato de sódio $(0,146 \mathrm{~g} / \mathrm{L}$ massa seca), propionato de sódio $(0,189 \mathrm{~g} / \mathrm{L}$ massa seca) e succinato de 
sódio $(0,161 \mathrm{~g} / \mathrm{L}$ massa seca). Ainda, quando se utilizou citrato de sódio, o valor de massa seca obtido foi maior que o controle $(0,271 \mathrm{~g} / \mathrm{L}$ massa seca e $0,250 \mathrm{~g} / \mathrm{L}$ massa seca, respectivamente). Também, verificou-se crescimento moderado em benzoato de sódio $(0,052 \mathrm{~g} / \mathrm{L}$ massa seca), etanol (0,085 $\mathrm{g} / \mathrm{L}$ massa seca $)$, frutose $(0,075 \mathrm{~g} / \mathrm{L}$ massa seca $)$, glicose (0,089 g/L massa seca) e metanol (0,082 g/L massa seca). Contudo, não houve crescimento da cultura na presença de fenol $(0,027 \mathrm{~g} / \mathrm{L}$ massa seca $)$, lactato de sódio $(0,017 \mathrm{~g} / \mathrm{L}$ massa seca $)$, e quando a única fonte orgânica fornecida foi o glutamato de sódio $(0,034 \mathrm{~g} / \mathrm{L}$ massa seca). Estes resultados podem ser visualizados na Figura 5.14.

Imhoff e Trüper (1989) não observaram crescimento para a bactéria fototrófica Rhodopseudomonas palustris, na presença de formiato e glutamato. Contudo, os mesmos autores constataram crescimento moderado em frutose e glicose, e crescimento elevado na presença de aspartato, benzoato, etanol e propionato. Zhang et al. (2002), trabalhando com a bactéria fototrófica Rhodopseudomonas faecalis sp. nov., observaram elevado crescimento em acetato, piruvato, lactato, malato, succinato e butirato; moderado crescimento em fumarato e propionato; e nenhum crescimento em benzoato, citrato, etanol, metanol e glutamato. No presente trabalho, utilizando cultura purificada de bactéria fototrófica púrpura não-sulfurosa, com predomínio de Rhodopseudomonas palustris, obteve-se elevado crescimento em butirato, citrato, piruvato, propionato e succinato. Moderado crescimento foi observado em benzoato, etanol, frutose, glicose e metanol; e nenhum crescimento em fenol, glutamato e lactato.

Com relação à produção de hidrogênio, o ensaio controle, com acetato de sódio, atingiu produção de $3,4 \mathrm{~mL}$ de $\mathrm{H}_{2}$ acumulado em $384 \mathrm{~h}$ de experimento, enquanto que nos ensaios com citrato de sódio, frutose, glicose, piruvato de sódio, propionato de sódio e succinato de sódio, as produções alcançadas foram de 3,69 mL H 2,40 $\mathrm{mL} \mathrm{H}_{2} ; 2,80 \mathrm{~mL} \mathrm{H}_{2}$ e 1,64 $\mathrm{mL} \mathrm{H}_{2}$; respectivamente (Figura 5.15). Entretanto, quando se 
utilizou benzoato de sódio, butirato de sódio, etanol, fenol, lactato de sódio, metanol e glutamato de sódio como fonte de carbono, a produção de hidrogênio foi nula.

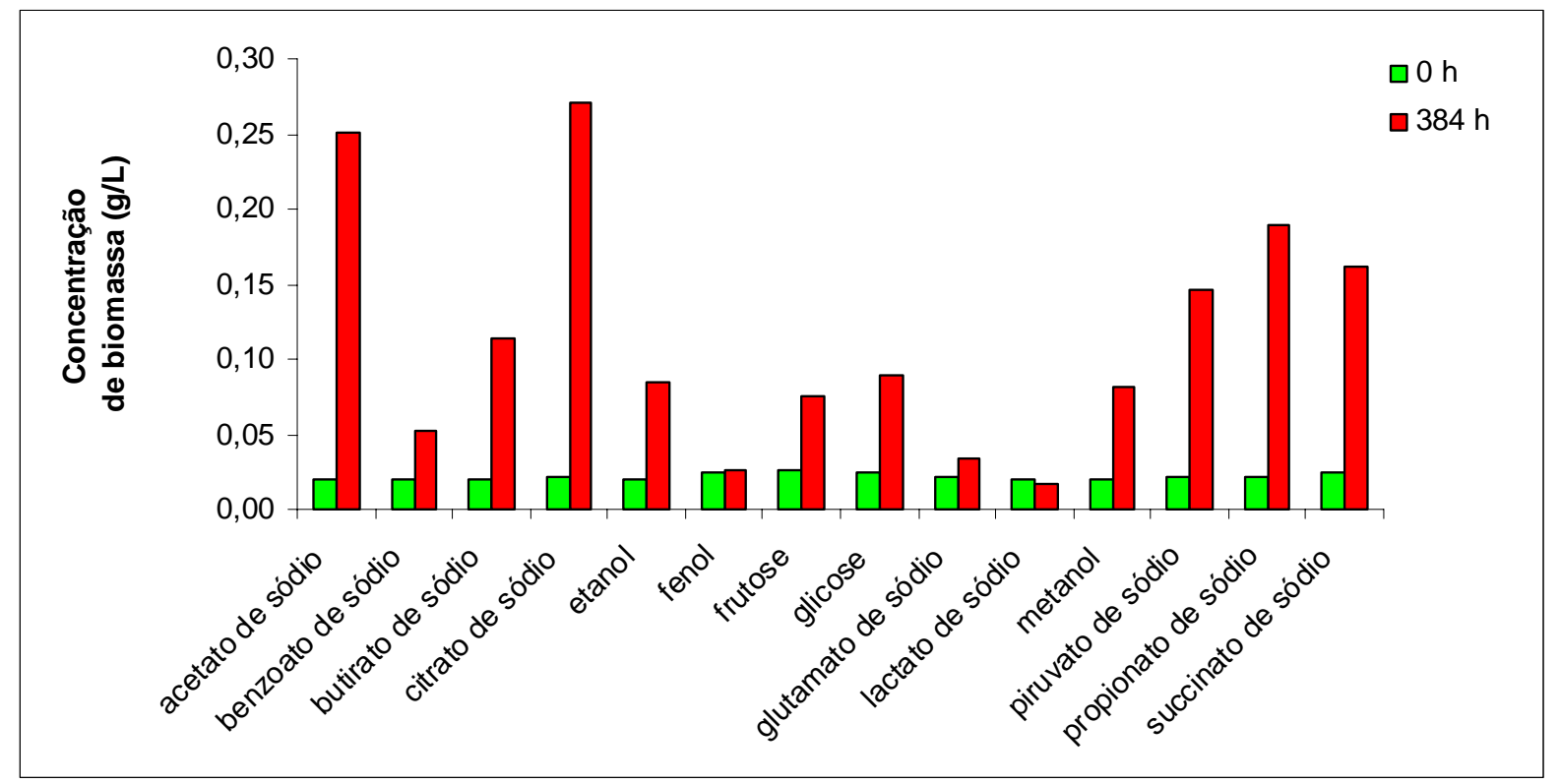

Figura 5.14. Crescimento celular da cultura de bactérias fototróficas púrpuras não-sulfurosas, na presença de diferentes substratos orgânicos

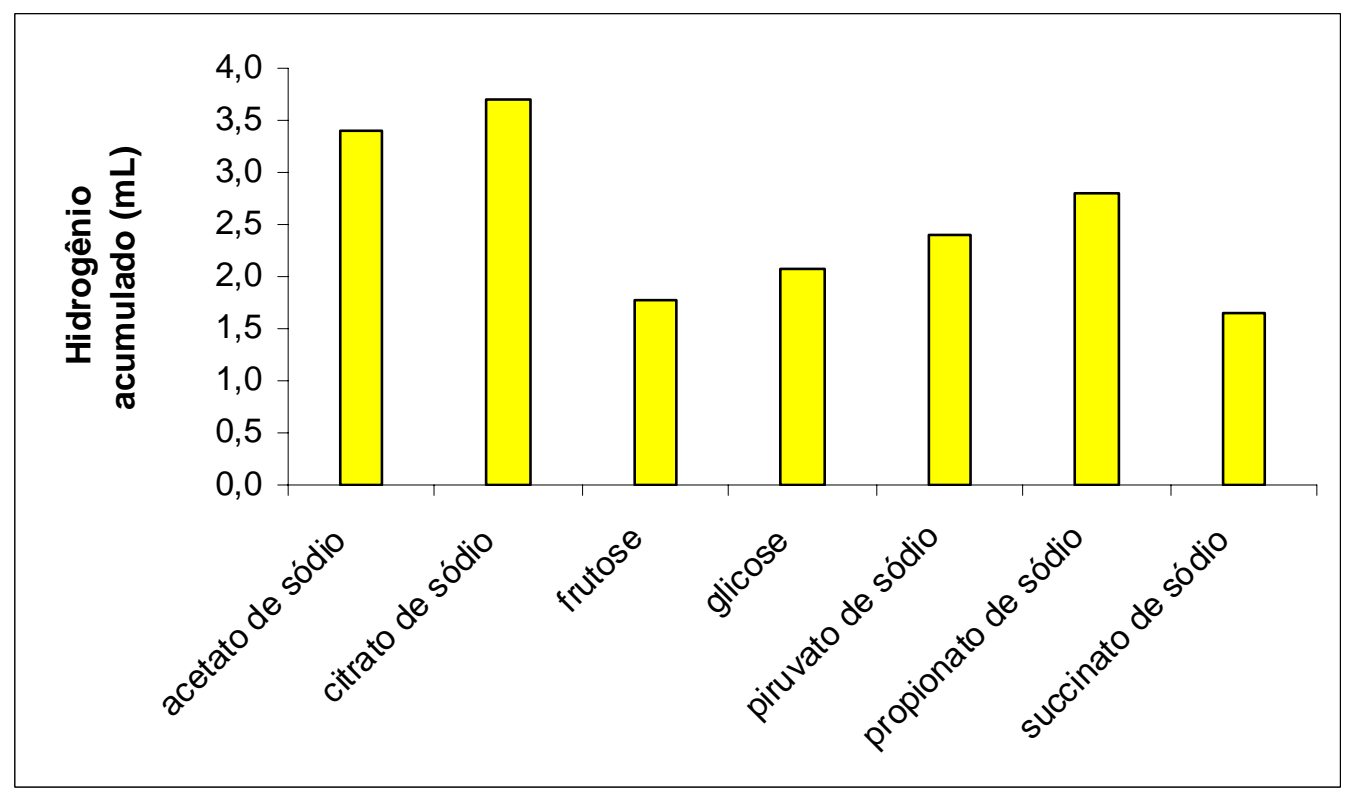

Figura 5.15. Produção de hidrogênio pela cultura de bactérias fototróficas púrpuras não-sulfurosas, na presença de diferentes substratos orgânicos 
De acordo com Koku et al. (2002), ampla variedade de substratos pode ser utilizada por bactérias fototróficas para crescimento, porém somente alguns destes estão disponíveis para produção de hidrogênio. Hillmer e Gest (1977), utilizando bactéria fototrófica Rhodopseudomonas capsulata, observaram produção elevada de hidrogênio na presença de lactato, piruvato e succinato; produção moderada em glicose, frutose e malato; e baixa produção na presença de butirato, propionato e sacarose. No presente trabalho, onde se utilizou cultura purificada de bactérias fototróficas, com predomínio de Rhodopseudomonas palustris, observou-se produção elevada de hidrogênio na presença de acetato e citrato; produção moderada em frutose, glicose, piruvato, propionato e succinato. Nenhuma produção foi observada em benzoato, butirato, etanol, fenol, glutamato, lactato e metanol.

A microscopia óptica de contraste de fase de amostra da cultura dos frascos alimentados com acetato de sódio, benzoato de sódio, citrato de sódio, fenol, lactato de sódio, metanol, piruvato de sódio e propionato de sódio, apresentou predomínio de bacilos curvos, aglomerados em formações de roseta (Figuras 5.16 e 5.17). Quando se utilizou succinato de sódio, embora ainda houvesse predominância de bacilos curvos, observou-se a presença de poucas células (Figura 5.18). Já no ensaio onde se utilizou apenas glutamato de sódio, houve predomínio de bacilos retos (Figura 5.19). Entretanto, quando a fonte de carbono utilizada foi butirato de sódio, etanol, frutose ou glicose, ocorreu não só o aparecimento de bacilos curvos formando aglomerados do tipo roseta, mas também bacilos retos e filamentos (Figura 5.20). 


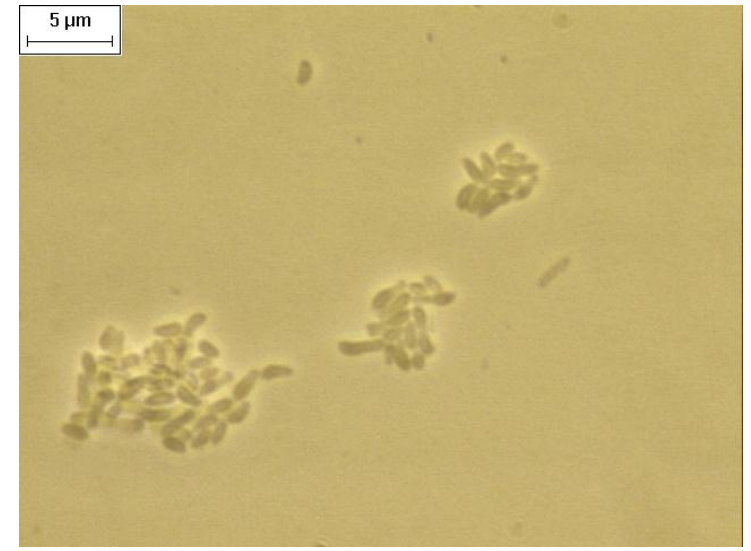

(a)

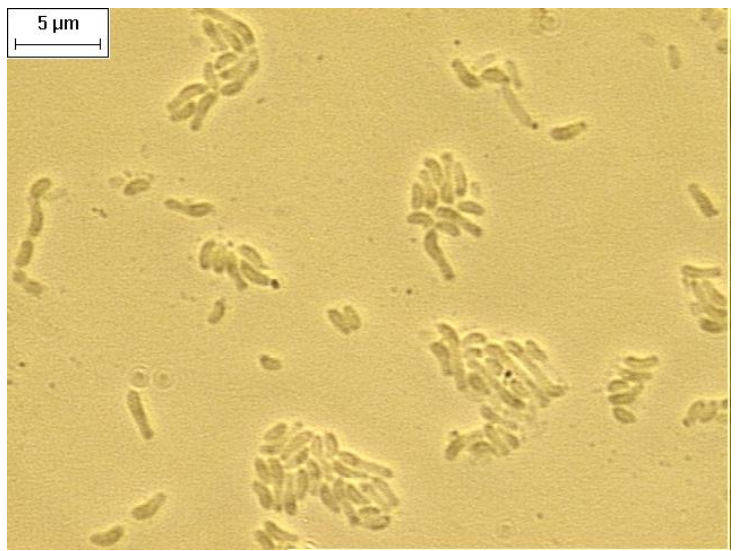

(c)

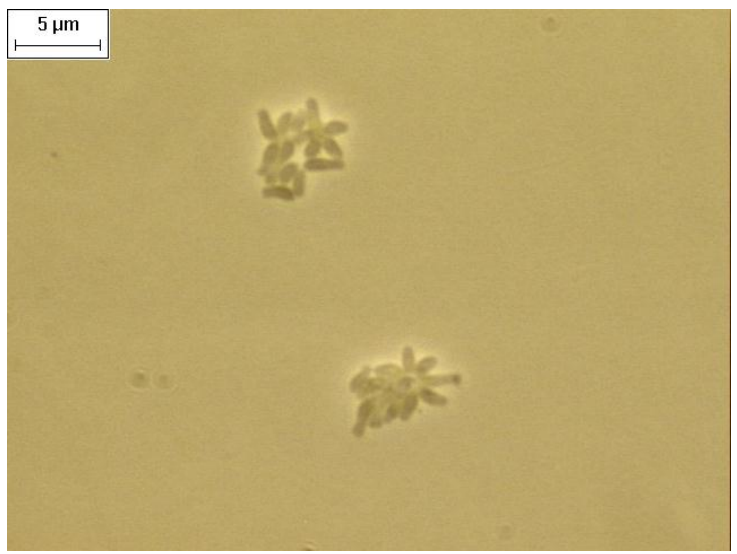

(e)

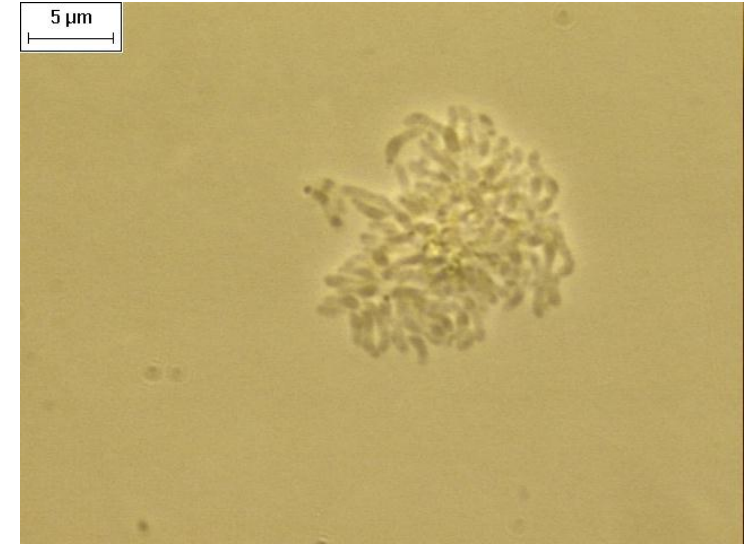

(b)

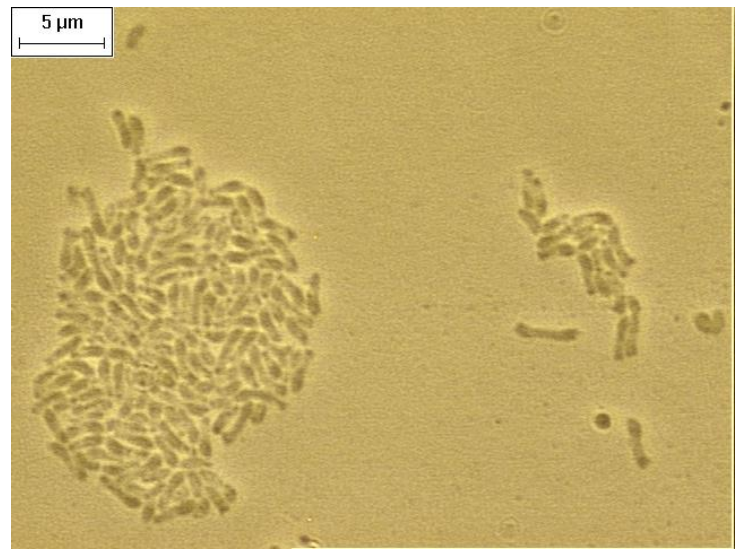

(d)

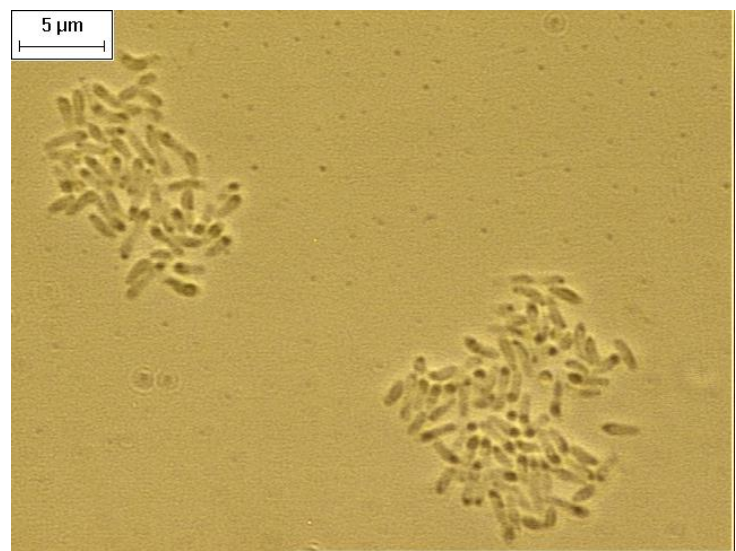

(f)

Figura 5.16. Predomínio de bacilos curvos aglomerados em formações de roseta, em microscopia óptica de contraste de fase de amostras dos frascos alimentados com: (a) acetato de sódio, (b) benzoato de sódio, (c) citrato de sódio, (d) fenol, (e) lactato de sódio e (f) metanol 


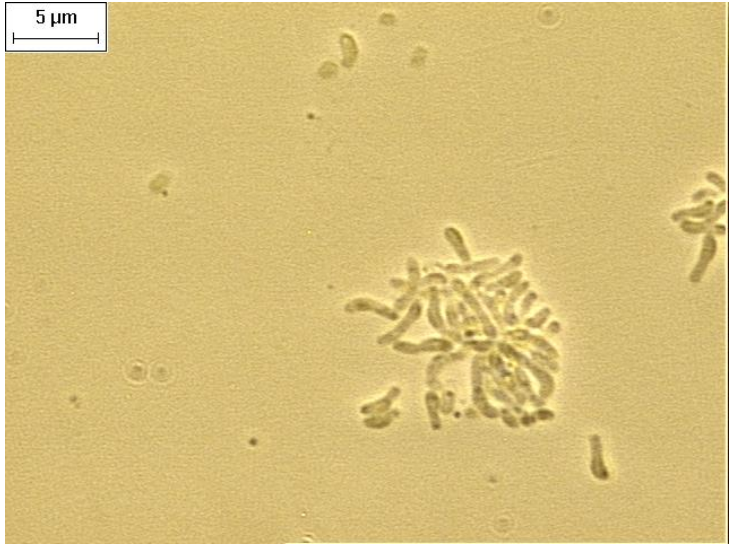

(a)

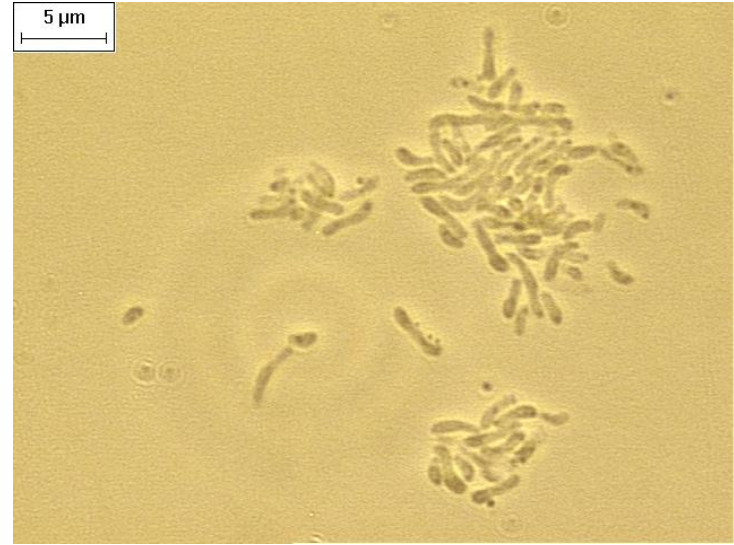

(b)

Figura 5.17. Predomínio de bacilos curvos aglomerados em formações de roseta, em microscopia óptica de contraste de fase de amostras dos frascos alimentados com: (a) piruvato de sódio e (b) propionato de sódio

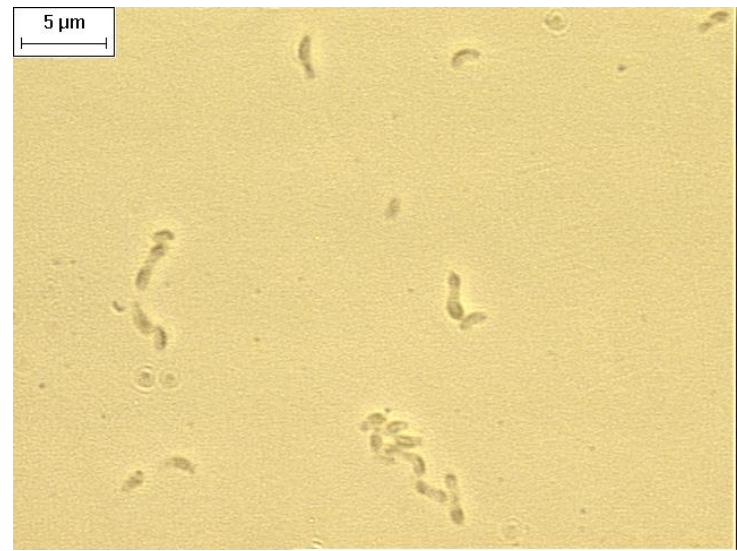

Figura 5.18. Microscopia óptica de contraste de fase de amostra do frasco alimentado com succinato de sódio

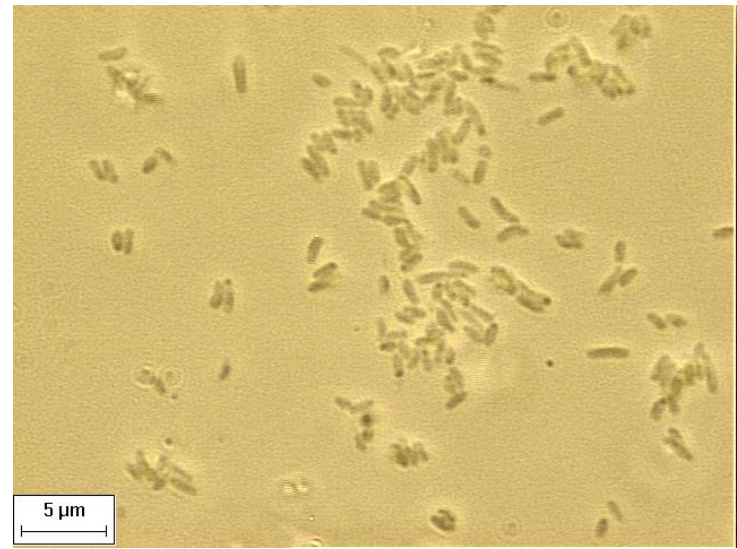

Figura 5.19. Predomínio de bacilos retos, em microscopia óptica de contraste de fase de amostra do frasco alimentado com glutamato de sódio 


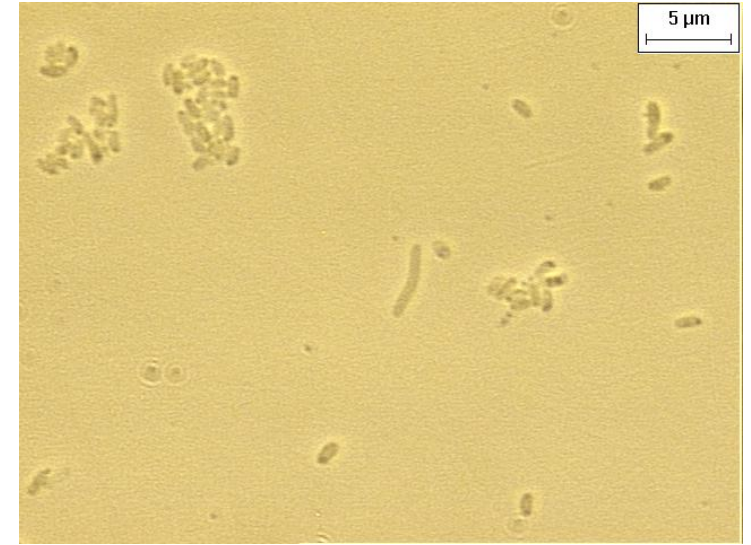

(a)

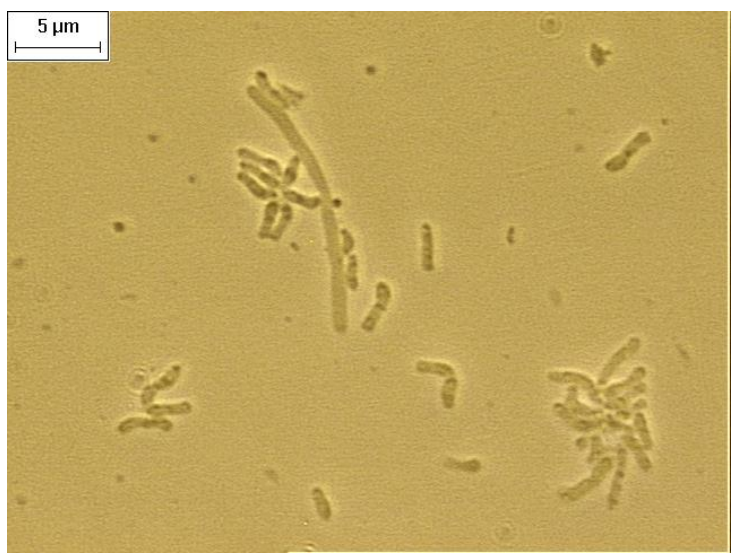

(c)

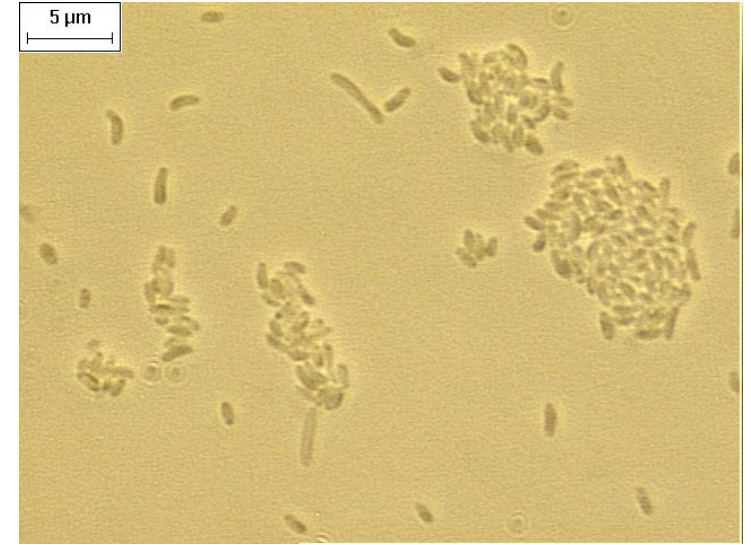

(b)

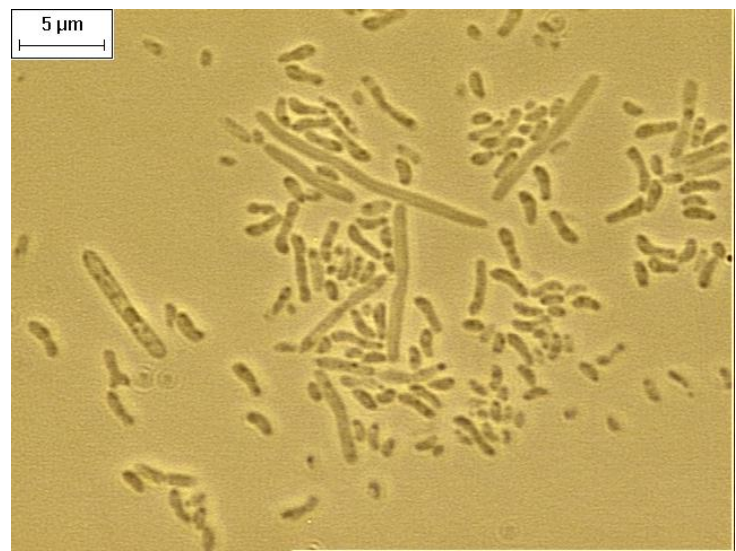

(d)

Figura 5.20. Bacilos curvos aglomerados em formações de roseta, bacilos retos e filamentos, em microscopia óptica de contraste de fase de amostras dos frascos alimentados com: (a) butirato de sódio, (b) etanol, (c) frutose e (d) glicose

Neste ensaio de caracterização, a coloração da cultura em suspensão variou de transparente, amarelada a púrpura (Figura 5.21). Um resumo do crescimento celular, produção de hidrogênio, morfologias predominantes e coloração da cultura em suspensão, do ensaio de caracterização nutricional, é mostrado na Tabela 5.2. 


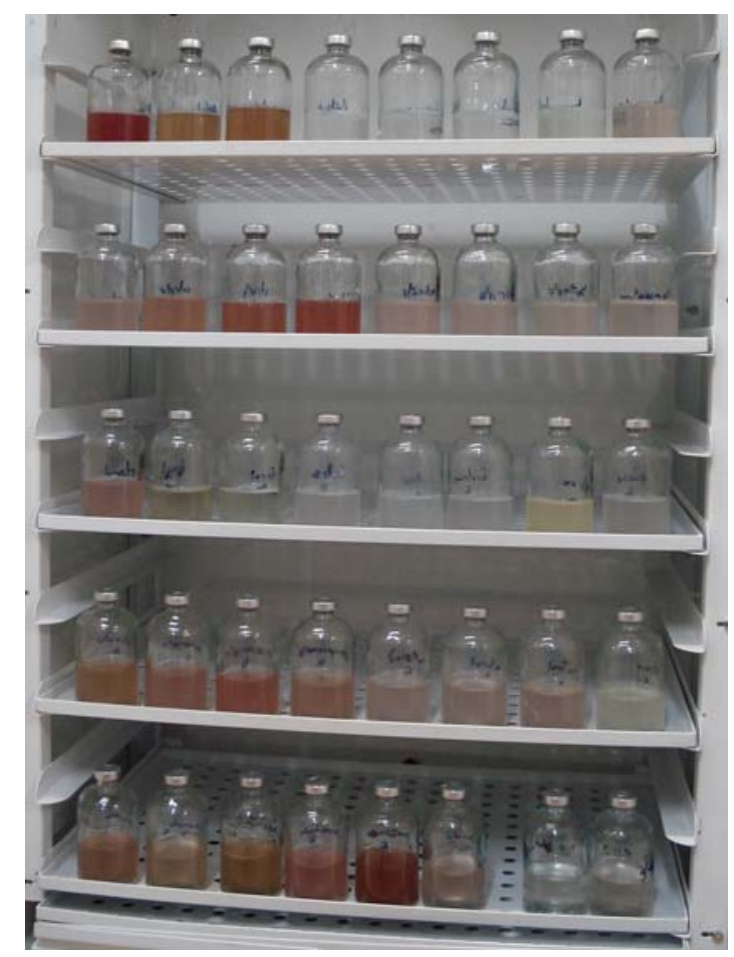

Figura 5.21. Foto dos frascos utilizados no ensaio de caracterização nutricional, mostrando as diferentes colorações da cultura em suspensão, na presença de diferentes substratos orgânicos

Tabela 5.2 - Crescimento celular, produção de hidrogênio, morfologias predominantes e coloração da cultura no ensaio de caracterização nutricional

\begin{tabular}{|c|c|c|c|c|}
\hline $\begin{array}{c}\text { Substratos } \\
\text { orgânicos } \\
(20 \mathrm{mmol} / \mathrm{L})\end{array}$ & Cresc. & $\begin{array}{c}\text { Produção } \\
\text { de } \mathrm{H}_{2}(\mathrm{~mL})\end{array}$ & $\begin{array}{c}\text { Morfologias } \\
\text { predominantes }\end{array}$ & $\begin{array}{c}\text { Coloração da } \\
\text { cultura }\end{array}$ \\
\hline acetato de sódio & + & 3,4 & bacilos curvos & púrpura \\
\hline benzoato de sódio & \pm & 0 & $\begin{array}{l}\text { bacilos curvos } \\
\text { bacilos curvos, bacilos }\end{array}$ & rosa claro \\
\hline butirato de sódio & + & 0 & retos e filamentos & rosa \\
\hline citrato de sódio & + & 3,69 & $\begin{array}{c}\text { bacilos curvos } \\
\text { bacilos curvos, bacilos }\end{array}$ & púrpura \\
\hline etanol & \pm & 0 & retos e filamentos & rosa claro \\
\hline fenol & - & 0 & $\begin{array}{l}\text { bacilos curvos } \\
\text { bacilos curvos, bacilos }\end{array}$ & amarela \\
\hline frutose & \pm & 1,76 & $\begin{array}{c}\text { retos e filamentos } \\
\text { bacilos curvos, bacilos }\end{array}$ & rosa claro \\
\hline glicose & \pm & 2,06 & retos e filamentos & rosa claro \\
\hline glutamato de sódio & - & 0 & bacilos retos & transparente \\
\hline lactato de sódio & - & 0 & bacilos curvos & transparente \\
\hline metanol & \pm & 0 & bacilos curvos & rosa claro \\
\hline piruvato de sódio & + & 2,40 & bacilos curvos & rosa \\
\hline propionato de sódio & + & 2,80 & bacilos curvos & rosa \\
\hline succinato de sódio & + & 1,64 & bacilos curvos & púrpura \\
\hline
\end{tabular}

+: crescimento elevado; \pm crescimento moderado; - nenhum crescimento 
De acordo com Bergey`s Manual of Systematic Bacteriology (1989), a bactéria fototrófica Rhodopseudomonas palustris apresenta coloração da cultura de púrpura a marrom; apresenta formato ovóide ou bacilar, as vezes levemente curvado; pode utilizar como fonte de carbono acetato, butirato, citrato, fumarato, glutamato, lactato, malato, piruvato, propionato e succinato; algumas linhagens utilizam etanol, frutose, glicose e metanol; e é a única espécie do gênero capaz de utilizar benzoato.

De acordo com os resultados obtidos no ensaio de enriquecimento, a cultura fototrófica utilizada só não teve seu crescimento favorecido na presença de fenol, glutamato de sódio e lactato de sódio. Nos substratos orgânicos onde o crescimento celular foi de elevado a moderado, ocorreu produção de hidrogênio, com exceção dos substratos benzoato de sódio, butirato de sódio, etanol e metanol. Logo, estes substratos favoreceram o crescimento da cultura fototrófica, mas não foram utilizados para produção de hidrogênio.

Em todos os substratos orgânicos utilizados, a morfologia predominante foi a de bacilos curvos, formando aglomerações de roseta, com exceção do glutamato de sódio, que mostrou predominância de bacilos retos. Além disso, substratos como butirato de sódio, etanol, frutose e glicose, favoreceram o surgimento de bactérias no formato de bacilos retos e filamentos. A coloração da cultura em suspensão pôde ser associada ao crescimento, uma vez que apresentou coloração de púrpura a rosa quando o crescimento foi elevado; coloração rosa claro quando o crescimento foi moderado; e coloração transparente a amarelada quando não houve crescimento celular. 


\section{CONCLUSÕES}

As principais conclusões deste trabalho foram:

- A cultura purificada de bactéria fototrófica púrpura não-sulfurosa mostrou potencial de produção de hidrogênio em reatores em batelada;

- O aumento da concentração inicial de ácido acético de $10 \mathrm{mmol} / \mathrm{L}$ para $17 \mathrm{mmol} / \mathrm{L}$ não promoveu mudanças significativas tanto no crescimento celular quanto na produção de hidrogênio;

- O aumento da concentração inicial de biomassa de $0,02 \mathrm{~g} / \mathrm{L}$ para $0,04 \mathrm{~g} / \mathrm{L}$ favoreceu o aumento da produção de hidrogênio;

- A diminuição na intensidade luminosa de 9000 a 10.000 lux para 4000 a 5000 lux promoveu diminuição rigorosa na velocidade de produção de hidrogênio;

- Análises microscópicas da comunidade microbiana presente nos ensaios de enriquecimento e de produção de hidrogênio mostraram a predominância de microrganismos com formato de bacilos curvos, Gram-negativos, aglomerados em formações de roseta; características típicas de alguns gêneros de bactérias fototróficas púrpuras não-sulfurosas com potencial de produzir hidrogênio;

- A análise de PCR/DGGE das amostras dos ensaios de produção de hidrogênio revelou elevada similaridade de bandas, ou seja, não houve variações relevantes na estrutura da comunidade microbiana em função das diferentes concentrações iniciais de ácido acético e biomassa, e também, devido a mudanças na intensidade luminosa fornecida;

- No ensaio de caracterização nutricional, a cultura fototrófica não teve seu crescimento favorecido na presença de fenol, glutamato de sódio e lactato de sódio; sendo que a produção de hidrogênio ocorreu nos substratos orgânicos onde o crescimento celular foi de elevado a moderado, como acetato de sódio, citrato de sódio, frutose, glicose, piruvato de sódio, propionato de sódio e succinato de sódio. A microscopia óptica de 
contraste de fase revelou a predominância de bacilos curvos em todos os substratos orgânicos utilizados, com exceção do glutamato de sódio, que mostrou predominância de bacilos retos. 


\section{RECOMENDAÇÕES}

Em relação a estudos posteriores, sugere-se:

- Avaliar o crescimento e a produção de hidrogênio da cultura fototrófica púrpura não-sulfurosa, utilizando efluente de reator anaeróbio acidogênico como fonte de nutrientes;

- Utilizar a bactéria fototrófica em sistema contínuo, para produção de hidrogênio. 


\section{REFERÊNCIAS BIBLIOGRÁFICAS}

AKKERMAN, I.; JANSSEN, M.; ROCHA, J.; WIJFFELS, R.H. (2002) Photobiolog ical hydrogen production: photochemical efficiency and bioreactor design. International Journal of Hydrogen Energy, v.27, p.1195-1208.

BARBOSA, M.J.; ROCHA, J.M.S.; TRAMPER, J.; WIJFFELS, R.H. (2001) Acetate as a carbon source for hydrogen production by photosynthetic bacteria. Journal of Biotechnology, v.85, p.25-33.

BERGEY'S MANUAL OF SYSTEMATIC BACTERIOLOGY. (1989) Edited by Staley, J.T., Bryant, M.P., Pfennig, N. and Holt, J.G., 1989, 2298p.

DAS, D.; VEZIROGLU, T.N. (2001) Hydrogen production by biological processes: a survey of literature. International Journal of Hydrogen Energy, v.26, p.13-28.

DSM, Scientific Services of Culture Collections. (1991) Curso Ministrado na Fundação Tropical de Pesquisa e Tecnologia André Tosello, Campinas.

EROGLU, I.; ASLAN, K.; GÜNDÜZ, U.; YÜCEL, M.; TÜRKER, L. (1999) Substrate consumption rates for hydrogen production by Rhodobacter sphaeroides in a column photobioreactor. Journal of Biotechnology, v.70, p.103-13.

FANG, H.H.P.; LIU, H.; ZHANG, T. (2005) Phototrophic hydrogen production from acetate and butyrate in wastewater. International Journal of Hydrogen Energy, v.30, p.785-93.

FASCETTI, E.; D’ADDARIO, E.; TODINI, O.; ROBERTIELLO, A. (1998) Photosynthetic hydrogen evolution with volatile organic acids derived from the fermentation of source selected municipal solid wastes. International Journal of Hydrogen Energy, v.23, n.9, p.753-60.

FEDOROV, A.S.; TSYGANKOV, A.A.; RAO, K.K.; HALL, D.O. (1998) Hydrogen photoproduction by Rhodobacter sphaeroides immobilised on polyurethane foam. Biotechnology Letters, v.20, n.11, p.1007-09.

GEST, H.; KAMEN, M.D. (1949) Photoproduction of molecular hydrogen by Rhodospirillum rubrum. Science, v.109, p.558-9. 
GRIFFITHS, R.I.; WHITELEY, A.S.; O`DONNELL, A.G. (2000) Rapid method for coextration of DNA from natural enviroments for analysis of ribossomal DNA and rRNA-based microbil community composition. Applied and Environmental Microbiology, v.66, n.12, p.5488-91.

HALLENBECK, P.; BENEMANN, J.R. (2002) Biological hydrogen production; fundamentals and limiting processes. International Journal of Hydrogen Energy, v.27, p.1185-93.

HE, D.; BULTEL, Y.; MAGNIN, J.P.; ROUX, C.; WILLISON, J.C. (2005) Hydrogen photosynthesis by Rhodobacter capsulatus and its coupling to a PEM fuel cell. Journal of Power Sources, v.141, p.19-23.

HE, D.; BULTEL, Y.; MAGNIN, J.P.; WILLISON, J.C. (2006) Kinetic analysis of photosynthetic growth and photohydrogen production of two strains of Rhodobacter capsulatus. Enzyme and Microbial Technology, v.38, p.253-9.

HILLMER, P.; GEST, H. (1977) $\mathrm{H}_{2}$ metabolism in photosynthetic bacterium Rhodopseudomonas capsulata: $\mathrm{H}_{2}$ production by growing cultures. Journal of Bacteriology, v.129, n.2, p.724-31.

IMHOFF, J.F.; TRÜPER, H.G. (1989) Purple nonsulfur bacteria. In: Bergey`s Manual of Systematic Bacteriology, v.3, p.1658-82. Edited by J.T. Staley, M.P. Bryant, N. Pfennig e J.G. Holt. Baltimore: Williams \& Wilkins.

INTERNATIONAL ENERGY ANNUAL. (2004) World total primary energy consumption, 1980-2004. Disponível em: <http://www.eia.doe.gov>. Acesso em: 2 dez. 2006.

KALIA, V.C.; LAL, S.; GHAI, R.; MANDAL, M.; CHAUHAN, A. (2003) Mining genomic databases to identify novel hydrogen producers. Trends in Biotechnology, v.21, n.4, p.152-56.

KOKU, H.; EROGLU, I.; GÜNDÜZ, U.; YÜCEL, M.; TÜRKER, L. (2002) Aspects of the metabolism of hydrogen production by Rhodobacter sphaeroides. International Journal of Hydrogen Energy, v.27, p.1315-29.

KONDO, T.; ARAKAWA, M.; HIRAI, T.; WAKAYAMA, T.; HARA, M.; MIYAKE, J. (2002) Enhancement of hydrogen production by a photosynthetic bacterium mutant with reduced pigment. Journal of Bioscience and Bioengineering, v.93, n.2, p.145-50.

LEVIN, D.B.; PITT, L.; LOVE, M. (2004) Biohydrogen production: prospects and limitations to practical application. International Journal of Hydrogen Energy, v.29, p.173-85. 
MADIGAN, M.T.; MARTINKO, J.M.; PARKER, J. (2004) Microbiologia de Brock. 10.ed. São Paulo: Prentice Hall.

MOMIRLAN, M.; VEZIROGLU, T.N. (2005) The properties of hydrogen as fuel tomorrow in sustainable energy system for a cleaner planet. International Journal of Hydrogen Energy, v.30, p.795-802.

MORAES, E.M.; ADORNO, A.T.; ZAIAT, M.; FORESTI, E. (2000) Determinação de ácidos voláteis por cromatografia gasosa em efluentes de reatores anaeróbios tratando resíduos líquidos e sólidos. In: OFICINA E SEMINÁRIO LATINO AMERICANO DE DIGESTÃO ANAERÓBIA, 6., 2000, Recife. p. 235-8.

NAJAFPOUR, G.; YOUNESI, H.; MOHAMED, A.R. (2004) Effect of organic substrate on hydrogen production from synthesis gas using Rhodospirillum rubrum in batch culture, v.21, p.123-30.

NAKADA, E.; ASADA, Y.; ARAI, T.; MIYAKE, J. (1995) Light penetration into cell suspensions of photosynthetic bacteria and relation to hydrogen production. Journal of Fermentation and Bioengineering, v.80, n.1, p.53-57.

NATH, K.; KUMAR, A.; DAS, D. (2005) Hydrogen production by Rhodobacter sphaeroides strain O.U.001 using spent media of Enterobacter cloacae strain DM11. Applied Microbial Biotechnology, v.68, p.533-41.

NIELSEN, A.T.; LIU, W.T.; FILIPE, C.; GRADY, L.; MOLIN, S.; STAHL, D.A. (1999) Identification of a novel group of bacteria in sludge from a deteriorated biological phosphorus removal reactor. Applied and Environmental Microbiology, v.65, n.3, p.1251-58.

OOSHIMA, H.; TAKAKUWA, S.; KATSUDA, T.; OKUDA, M.; SHIRASAWA, T.; AZUMA, M.; KATO, J. (1998) Production of hydrogen by a hydrogenase-deficient mutant of Rhodobacter capsulatus. Journal of Fermentation and Bioengineering, v.85, n.5, p.470-75.

SAAVEDRA, N.K.; SAKAMOTO, I.K.; VARESCHE, M.B.A. (2005) Avaliação da diversidade de bactérias fototróficas anoxigênicas em lagoa de estabilização anaeróbia. In: TALLER Y SIMPOSIO LATINOAMERICANO SOBRE DIGESTION ANAEROBIA, 7., 2005, Punta del Este, Uruguay.

SASIKALA, K.; RAMANA, C.V.; RAO, P.R. (1991) Environmental regulation for optimal biomass yield and photoproduction of hydrogen by Rhodobacter sphaeroides O.U. 001. International Journal of Hydrogen Energy, v.16, n.9, p.597-601. 
SASIKALA, K.; RAMANA, C.V.; RAO, P.R. (1992) Photoproduction of hydrogen from the waste water of a distillery by Rhodobacter sphaeroides O.U. 001. International Journal of Hydrogen Energy, v.17, n.1, p.23-27.

STANDARD METHODS FOR EXAMINATION OF WATER AND WASTEWATER (1998). 20th ed. American Public Health Association / American Water Works Association / Water Environment Federation, Washington, DC, USA.

VAN NIEL, C.B. (1944) The culture, general physiology, morphology and classification of the non-sulfur purple and brown bacteria. Bacteriological Reviews, v.8, p.1-118.

VARESCHE, M.B.A. (1997) Estudo com bactérias fototróficas anoxigênicas: enriquecimento, isolamento, caracterização nutricional e cinética de crescimento. 1997. 363 f. Tese (Doutorado) - Escola de Engenharia de São Carlos, Universidade de São Paulo, São Carlos, 1997.

VINCENZINI, M.; MATERASSI, R.; TREDICI, M.R.; FLORENZANO, G. (1982) Hydrogen production by immobilized cells $-\mathrm{H}_{2}$ photoevolution and wastewater treatment by agar-entrapped cells of Rhodopseudomonas palustris and Rhodospirillum molischianum. International Journal of Hydrogen Energy, v.7, n.9, p.725-28.

VINCENZINI, M.; MARCHINI, A.; ENA, A.; PHILIPPIS, R. (1997) $\mathrm{H}_{2}$ and poly- $\beta$ hydroxybutyrate, two alternative chemicals from purple non sulfur bacteria. Biotechnology Letters, v.19, n.8, p.759-62.

YETIS, M.; GÜNDÜZ, U.; EROGLU, I.; YÜCEL, M.; TÜRKER, L. (2000) Photoproduction of hydrogen from sugar refinery wastewater by Rhodobacter sphaeroides O.U. 001. International Journal of Hydrogen Energy, v.25, p.1035-41.

YOKOI, H.; MORI, S.; HIROSE, J.; HAYASHI, S.; TAKASAKI, Y. (1998) $\mathrm{H}_{2}$ production from starch by a mixed culture of Clostridium butyricum and Rhodobacter sp. M-19. Biotechnology Letters, v.20, n.9, p.895-99.

YOKOI, H.; MAKI, R.; HIROSE, J.; HAYASHI, S. (2002) Microbial production of hydrogen from starch-manufacturing wastes. Biomass and Bioenergy, v.22, p.389-95.

ZHANG, D.; YANG, H.; HUANG, Z.; ZHANG, W; LIU, S. (2002) Rhodopseudomonas faecalis sp. Nov., a phototrophic bacterium isolated from an anaerobic reactor that digests chicken faeces. International Journal of Systematic and Evolutionary Microbiology, v.52, p.2055-60. 
ZHU, H.; SUZUKI, T.; TSYGANKOV, A.A.; ASADA, Y.; MIYAKE, J. (1999) Hydrogen production from tofu wastewater by Rhodobacter sphaeroides immobilized in agar gels. International Journal of Hydrogen Energy, v.24, p.305-10.

ZHU, H.; WAKAYAMA, T.; ASADA, Y.; MIYAKE, J. (2001) Hydrogen production by four cultures with participation by anoxygenic phototrophic bacterium and anaerobic bacterium in the presence of $\mathrm{NH}_{4}{ }^{+}$. International Journal of Hydrogen Energy, v.26, p.1149-54.

ZÜRRER, H.; BACHOFEN, R. (1979) Hydrogen production by the photosynthetic bacterium Rhodospirillum rubrum. Applied and Environmental Microbiology, v.37, n.5, p.789-93. 
APÊNDICE 1 - Curva-padrão de crescimento de bactéria fototrófica púrpura nãosulfurosa

\begin{tabular}{ccccccc}
\hline $\begin{array}{c}\text { Tempo } \\
\text { (h) }\end{array}$ & \multicolumn{2}{c}{ Absorbância (660 nm) } & \multicolumn{3}{c}{ Massa seca (g/L) } \\
\hline $\mathbf{0}$ & Reator 1 & Reator 2 & Média & Reator 1 & Reator 2 & Média \\
$\mathbf{2 4}$ & 0,011 & 0,012 & 0,012 & 0,0133 & 0,0156 & 0,0144 \\
$\mathbf{4 8}$ & 0,028 & 0,034 & 0,031 & 0,0267 & 0,0467 & 0,0367 \\
$\mathbf{7 2}$ & 0,047 & 0,050 & 0,049 & 0,0578 & 0,0467 & 0,0522 \\
$\mathbf{9 6}$ & 0,071 & 0,069 & 0,070 & 0,0578 & 0,0511 & 0,0544 \\
$\mathbf{1 2 0}$ & 0,100 & 0,107 & 0,104 & 0,0689 & 0,0867 & 0,0778 \\
$\mathbf{1 4 4}$ & 0,133 & 0,140 & 0,137 & 0,1111 & 0,1067 & 0,1089 \\
$\mathbf{1 6 8}$ & 0,178 & 0,169 & 0,174 & 0,1178 & 0,1289 & 0,1233 \\
\hline
\end{tabular}


APÊNDICE 2 - Tempo de experimento, valores de absorbância e concentração de massa seca obtidos nos reatores anaeróbios em batelada

\begin{tabular}{|c|c|c|c|c|c|}
\hline \multicolumn{6}{|c|}{ Ensaio 1 - Ácido acético (10 mmol/L) e biomassa inicial $(0,02$ g/L) } \\
\hline \multirow[b]{2}{*}{ Tempo (h) } & \multicolumn{4}{|c|}{ Absorbância (660 nm) } & \multirow{2}{*}{$\begin{array}{c}\text { Concentração média } \\
\text { de massa seca } \\
(\mathrm{g} / \mathrm{L})\end{array}$} \\
\hline & reator 1 & reator 2 & reator 3 & média & \\
\hline $\mathbf{0}$ & 0,025 & 0,028 & 0,031 & 0,028 & 0,018 \\
\hline 24 & 0,048 & 0,044 & 0,046 & 0,046 & 0,030 \\
\hline 48 & 0,051 & 0,058 & 0,055 & 0,055 & 0,036 \\
\hline 72 & 0,066 & 0,071 & 0,068 & 0,068 & 0,045 \\
\hline 96 & 0,078 & 0,093 & 0,079 & 0,083 & 0,055 \\
\hline 120 & 0,102 & 0,113 & 0,090 & 0,102 & 0,067 \\
\hline 144 & 0,129 & 0,149 & 0,126 & 0,135 & 0,089 \\
\hline 168 & 0,161 & 0,191 & 0,161 & 0,171 & 0,113 \\
\hline 192 & 0,167 & 0,204 & 0,180 & 0,184 & 0,121 \\
\hline 216 & 0,204 & 0,266 & 0,211 & 0,227 & 0,150 \\
\hline 240 & 0,248 & 0,306 & 0,257 & 0,270 & 0,178 \\
\hline 288 & 0,279 & 0,315 & 0,267 & 0,287 & 0,189 \\
\hline 360 & 0,291 & 0,321 & 0,272 & 0,295 & 0,194 \\
\hline 384 & 0,265 & 0,298 & 0,281 & 0,281 & 0,186 \\
\hline 408 & 0,263 & 0,278 & 0,274 & 0,272 & 0,179 \\
\hline
\end{tabular}

Ensaio 2 - Ácido acético (17 mmol/L) e biomassa inicial $(0,02 \mathrm{~g} / \mathrm{L})$ Absorbância (660 nm)

Concentração média de massa seca

\begin{tabular}{cccccc} 
Tempo (h) & reator $\mathbf{1}$ & reator 2 & reator 3 & média & $\mathbf{( g / L )}$ \\
\hline $\mathbf{0}$ & 0,028 & 0,030 & 0,031 & 0,030 & 0,020 \\
$\mathbf{2 4}$ & 0,043 & 0,044 & 0,039 & 0,042 & 0,028 \\
$\mathbf{4 8}$ & 0,060 & 0,051 & 0,054 & 0,055 & 0,036 \\
$\mathbf{7 2}$ & 0,071 & 0,064 & 0,061 & 0,065 & 0,043 \\
$\mathbf{9 6}$ & 0,082 & 0,078 & 0,068 & 0,076 & 0,050 \\
$\mathbf{1 2 0}$ & 0,115 & 0,101 & 0,083 & 0,100 & 0,066 \\
$\mathbf{1 4 4}$ & 0,196 & 0,119 & 0,114 & 0,143 & 0,094 \\
$\mathbf{1 6 8}$ & 0,241 & 0,162 & 0,148 & 0,184 & 0,121 \\
$\mathbf{1 9 2}$ & 0,317 & 0,176 & 0,182 & 0,225 & 0,149 \\
$\mathbf{2 1 6}$ & 0,332 & 0,233 & 0,235 & 0,267 & 0,176 \\
$\mathbf{2 4 0}$ & 0,323 & 0,284 & 0,269 & 0,292 & 0,193 \\
$\mathbf{2 8 8}$ & 0,347 & 0,296 & 0,272 & 0,305 & 0,201 \\
$\mathbf{3 6 0}$ & 0,368 & 0,307 & 0,263 & 0,313 & 0,206 \\
$\mathbf{3 8 4}$ & 0,399 & 0,301 & 0,316 & 0,339 & 0,224 \\
$\mathbf{4 0 8}$ & 0,368 & 0,292 & 0,264 & 0,308 & 0,203
\end{tabular}




\begin{tabular}{|c|c|c|c|c|c|}
\hline \multicolumn{6}{|c|}{ Ensaio 3 - Ácido acético (18 mmol/L) e biomassa inicial $(0,04 \mathrm{~g} / \mathrm{L})$} \\
\hline \multirow[b]{2}{*}{ Tempo (h) } & \multicolumn{4}{|c|}{ Absorbância (660 nm) } & \multirow{2}{*}{$\begin{array}{c}\text { Concentração média } \\
\text { de massa seca } \\
(\mathrm{g} / \mathrm{L})\end{array}$} \\
\hline & reator 1 & reator 2 & reator 3 & média & \\
\hline $\mathbf{0}$ & 0,058 & 0,054 & 0,054 & 0,055 & 0,037 \\
\hline 24 & 0,066 & 0,066 & 0,070 & 0,067 & 0,044 \\
\hline 48 & 0,084 & 0,096 & 0,102 & 0,094 & 0,062 \\
\hline 72 & 0,097 & 0,116 & 0,120 & 0,111 & 0,073 \\
\hline 96 & 0,121 & 0,125 & 0,138 & 0,128 & 0,084 \\
\hline 120 & 0,141 & 0,161 & 0,163 & 0,155 & 0,102 \\
\hline 144 & 0,171 & 0,209 & 0,216 & 0,199 & 0,131 \\
\hline 192 & 0,244 & 0,306 & 0,285 & 0,278 & 0,184 \\
\hline 216 & 0,308 & 0,298 & 0,326 & 0,311 & 0,205 \\
\hline 240 & 0,335 & 0,315 & 0,346 & 0,332 & 0,219 \\
\hline 264 & 0,328 & 0,336 & 0,337 & 0,334 & 0,220 \\
\hline 288 & 0,324 & 0,316 & 0,382 & 0,341 & 0,225 \\
\hline 360 & 0,298 & 0,309 & 0,375 & 0,327 & 0,216 \\
\hline 384 & 0,311 & 0,275 & 0,319 & 0,302 & 0,199 \\
\hline 408 & 0,294 & 0,285 & 0,350 & 0,310 & 0,204 \\
\hline
\end{tabular}

Ensaio 4 - Ácido acético (22 mmol/L) e biomassa inicial (0,04 g/L) Absorbância (660 nm)

Concentração média

\begin{tabular}{ccccc} 
Tempo (h) & reator $\mathbf{1}$ & reator 2 & média & $\begin{array}{c}\text { de massa seca } \\
(\mathbf{g} / \mathbf{L})\end{array}$ \\
\hline $\mathbf{0}$ & 0,053 & 0,056 & 0,055 & 0,036 \\
$\mathbf{2 4}$ & 0,065 & 0,073 & 0,069 & 0,046 \\
$\mathbf{4 8}$ & 0,080 & 0,085 & 0,083 & 0,054 \\
$\mathbf{7 2}$ & 0,106 & 0,116 & 0,111 & 0,073 \\
$\mathbf{9 6}$ & 0,138 & 0,140 & 0,139 & 0,092 \\
$\mathbf{1 2 0}$ & 0,166 & 0,158 & 0,162 & 0,107 \\
$\mathbf{1 4 4}$ & 0,230 & 0,212 & 0,221 & 0,146 \\
$\mathbf{1 6 8}$ & 0,254 & 0,214 & 0,234 & 0,154 \\
$\mathbf{1 9 2}$ & 0,290 & 0,278 & 0,284 & 0,187 \\
$\mathbf{2 1 6}$ & 0,264 & 0,290 & 0,277 & 0,183 \\
$\mathbf{2 4 0}$ & 0,275 & 0,308 & 0,292 & 0,192 \\
$\mathbf{2 6 4}$ & 0,258 & 0,287 & 0,273 & 0,180 \\
$\mathbf{2 8 8}$ & 0,276 & 0,324 & 0,300 & 0,198 \\
$\mathbf{3 3 6}$ & 0,258 & 0,324 & 0,291 & 0,192 \\
$\mathbf{4 0 8}$ & 0,290 & 0,327 & 0,309 & 0,204 \\
\hline
\end{tabular}


Ensaio 5 - Ácido acético (22 mmol/L) e biomassa inicial $(0,04 \mathrm{~g} / \mathrm{L})$

Absorbância (660 nm)

Concentração média

\begin{tabular}{cccccc} 
Tempo (h) & reator $\mathbf{1}$ & reator 2 & reator 3 & média & $\begin{array}{c}\text { de massa seca } \\
\mathbf{( g / L )}\end{array}$ \\
\hline $\mathbf{0}$ & 0,052 & 0,053 & 0,052 & 0,052 & 0,035 \\
$\mathbf{2 4}$ & 0,051 & 0,052 & 0,052 & 0,051 & 0,034 \\
$\mathbf{4 8}$ & 0,032 & 0,041 & 0,045 & 0,032 & 0,026 \\
$\mathbf{7 2}$ & 0,039 & 0,041 & 0,045 & 0,039 & 0,028 \\
$\mathbf{9 6}$ & 0,043 & 0,045 & 0,048 & 0,043 & 0,030 \\
$\mathbf{1 2 0}$ & 0,048 & 0,050 & 0,048 & 0,048 & 0,032 \\
$\mathbf{1 4 4}$ & 0,039 & 0,042 & 0,049 & 0,039 & 0,029 \\
$\mathbf{1 6 8}$ & 0,043 & 0,044 & 0,042 & 0,043 & 0,028 \\
$\mathbf{1 9 2}$ & 0,045 & 0,042 & 0,051 & 0,045 & 0,030 \\
$\mathbf{2 1 6}$ & 0,038 & 0,037 & 0,044 & 0,038 & 0,026 \\
$\mathbf{2 4 0}$ & 0,043 & 0,044 & 0,049 & 0,043 & 0,030 \\
$\mathbf{2 8 8}$ & 0,037 & 0,038 & 0,040 & 0,037 & 0,025 \\
$\mathbf{3 3 6}$ & 0,038 & 0,040 & 0,039 & 0,038 & 0,026 \\
$\mathbf{4 0 8}$ & 0,039 & 0,050 & 0,045 & 0,039 & 0,029 \\
\hline
\end{tabular}


APÊNDICE 3 - Tempo de experimento, área cromatográfica e valores de hidrogênio acumulado no headspace dos reatores anaeróbios em batelada

\begin{tabular}{|c|c|c|c|c|c|}
\hline \multicolumn{6}{|c|}{ Ensaio 1 - Ácido acético (10 mmol/L) e biomassa inicial $(0,02$ g/L) } \\
\hline \multirow[b]{2}{*}{ Tempo (h) } & \multicolumn{4}{|c|}{ Área cromatográfica do hidrogênio } & \multirow{2}{*}{$\begin{array}{c}\text { Concentração média } \\
\text { de } \mathrm{H}_{2} \text { no headspace } \\
(\mathrm{mL} / \mathrm{L})\end{array}$} \\
\hline & reator 1 & reator 2 & reator 3 & média & \\
\hline $\mathbf{0}$ & 0 & 0 & 0 & 0,0 & 0 \\
\hline 24 & 22467,7 & 14414,0 & 21245,6 & 19375,8 & 0 \\
\hline 48 & 52955,5 & 59994,2 & 62364,8 & 58438,2 & 0 \\
\hline 72 & 107676,8 & 124807,8 & 108539,2 & 113674,6 & 3,18 \\
\hline 96 & 159869,7 & 193323,1 & 157941,9 & 170378,2 & 14,12 \\
\hline 120 & 225226,2 & 285445,0 & 224684,0 & 245118,4 & 28,54 \\
\hline 144 & 287770,2 & 342083,3 & 307075,5 & 312309,7 & 41,51 \\
\hline 168 & 367733,2 & 495078,2 & 381681,9 & 414831,1 & 61,29 \\
\hline 192 & 406845,3 & 507490,6 & 433505,1 & 449280,3 & 67,94 \\
\hline 216 & 487178,9 & 534511,2 & 513575,1 & 511755,1 & 79,99 \\
\hline 240 & 430133,5 & 687966,7 & 478687,1 & 532262,4 & 83,95 \\
\hline 288 & 556122,3 & 686707,5 & 512677,8 & 585169,2 & 94,16 \\
\hline 360 & 587748,4 & 640510,4 & 739790,5 & 656016,4 & 107,83 \\
\hline 384 & 744087,9 & 795304,2 & 418840,2 & 652744,1 & 107,20 \\
\hline 408 & 344858,0 & 496936,4 & 413259,9 & 418351,4 & 61,97 \\
\hline
\end{tabular}

Ensaio 2 - Ácido acético (17 mmol/L) e biomassa inicial $(0,02 \mathrm{~g} / \mathrm{L})$ Área cromatográfica do hidrogênio Concentração média

\begin{tabular}{cccccc} 
Tempo (h) & reator 1 & reator 2 & reator 3 & média & (mL/L) \\
\hline $\mathbf{0}$ & 0,0 & 0,0 & 0,0 & 0,0 & 0 \\
$\mathbf{2 4}$ & 0,0 & 6558,8 & 9460,7 & 5339,8 & 0 \\
$\mathbf{4 8}$ & 35973,2 & 52346,4 & 49161,2 & 45826,9 & 0 \\
$\mathbf{7 2}$ & 100499,4 & 109107,4 & 96394,3 & 102000,4 & 0,93 \\
$\mathbf{9 6}$ & 120473,6 & 120337,4 & 124141,8 & 121650,9 & 4,72 \\
$\mathbf{1 2 0}$ & 216929,2 & 202809,0 & 202369,8 & 207369,3 & 21,26 \\
$\mathbf{1 4 4}$ & 302701,1 & 279857,9 & 260674,2 & 281077,7 & 35,48 \\
$\mathbf{1 6 8}$ & 356544,7 & 351248,8 & 347302,9 & 351698,8 & 49,11 \\
$\mathbf{1 9 2}$ & 488624,4 & 452069,8 & 428868,3 & 456520,8 & 69,34 \\
$\mathbf{2 1 6}$ & 574379,3 & 445679,0 & 486010,3 & 502022,9 & 78,12 \\
$\mathbf{2 4 0}$ & 525286,8 & 528568,0 & 556313,9 & 536722,9 & 84,81 \\
$\mathbf{2 8 8}$ & 543178,3 & 696164,9 & 712259,8 & 650534,3 & 106,77 \\
$\mathbf{3 6 0}$ & 568341,2 & 712329,9 & 854292,8 & 711654,6 & 118,57 \\
$\mathbf{3 8 4}$ & 577625,7 & 649614,0 & 506375,7 & 577871,8 & 92,75 \\
$\mathbf{4 0 8}$ & 426073,3 & 630607,3 & 567467,4 & 541382,7 & 85,71 \\
\hline
\end{tabular}




\begin{tabular}{cccccc}
\hline \multicolumn{6}{c}{ Ensaio 3 - Ácido acético (18 mmol/L) e biomassa inicial (0,04 g/L) } \\
\hline \multicolumn{7}{c}{ Área cromatográfica do hidrogênio } & $\begin{array}{c}\text { Concentração média } \\
\text { de H }\end{array}$ no headspace \\
Tempo (h) & reator 1 & reator $\mathbf{2}$ & reator 3 & média & 0 \\
\hline $\mathbf{0}$ & 0,0 & 0,0 & 0,0 & 0,0 & 0 \\
$\mathbf{2 4}$ & 8773,8 & 15084,1 & 13786,3 & 12548,1 & 0 \\
$\mathbf{4 8}$ & 85949,8 & 88375,6 & 97855,3 & 90726,9 & 18,04 \\
$\mathbf{7 2}$ & 176462,2 & 189226,5 & 206384,6 & 190691,1 & 30,94 \\
$\mathbf{9 6}$ & 257270,6 & 229386,1 & 285935,1 & 257530,6 & 59,06 \\
$\mathbf{1 2 0}$ & 336646,6 & 406056,5 & 467081,5 & 403261,5 & 61,97 \\
$\mathbf{1 4 4}$ & 388025,5 & 425553,1 & 441516,4 & 418365,0 & 73,99 \\
$\mathbf{1 9 2}$ & 480542,8 & 509432,9 & 452006,5 & 480660,7 & 86,34 \\
$\mathbf{2 1 6}$ & 595584,7 & 521077,5 & 517226,2 & 544629,5 & 85,33 \\
$\mathbf{2 4 0}$ & 558231,2 & 517579,6 & 542406,3 & 539405,7 & 117,32 \\
$\mathbf{2 6 4}$ & 709454,8 & 693725,4 & 712329,9 & 705170,0 & 106,57 \\
$\mathbf{2 8 8}$ & 701981,6 & 606475,9 & 640058,6 & 649505,4 & 104,14 \\
$\mathbf{3 6 0}$ & 636035,8 & 613443,3 & 661242,0 & 636907,0 & 127,03 \\
$\mathbf{3 8 4}$ & 735316,5 & 695110,4 & 836143,2 & 755523,4 & 115,92 \\
$\mathbf{4 0 8}$ & 628287,7 & 631516,2 & 834093,8 & 697965,9 & \\
\hline
\end{tabular}

Ensaio 4 - Ácido acético (22 mmol/L) e biomassa inicial (0,04 g/L) Área cromatográfica do hidrogênio Concentração média

\begin{tabular}{ccccc} 
Tempo (h) & reator $\mathbf{1}$ & reator 2 & média & $\begin{array}{c}\text { Concentração média } \\
\text { de } \mathbf{H}_{\mathbf{2}} \text { no headspace } \\
\text { (mL/L) }\end{array}$ \\
\hline $\mathbf{0}$ & 0,0 & 0,0 & 0,0 & 0 \\
$\mathbf{2 4}$ & 11254,2 & 28700,6 & 19977,4 & 0 \\
$\mathbf{4 8}$ & 20339,3 & 23750,3 & 22044,8 & 0 \\
$\mathbf{7 2}$ & 104754,6 & 106089,6 & 105422,1 & 1,59 \\
$\mathbf{9 6}$ & 162316,8 & 151666,2 & 156991,5 & 11,54 \\
$\mathbf{1 2 0}$ & 188703,7 & 163108,7 & 175906,2 & 15,19 \\
$\mathbf{1 4 4}$ & 244094,5 & 188172,6 & 216133,6 & 22,95 \\
$\mathbf{1 6 8}$ & 257788,3 & 166829,1 & 212308,7 & 22,21 \\
$\mathbf{1 9 2}$ & 331582,5 & 198490,2 & 265036,4 & 32,39 \\
$\mathbf{2 1 6}$ & 374395,6 & 184706,5 & 279551,1 & 35,19 \\
$\mathbf{2 4 0}$ & 467500,6 & 187442,3 & 327471,5 & 44,43 \\
$\mathbf{2 6 4}$ & 454019,7 & 225101,5 & 339560,6 & 46,77 \\
$\mathbf{2 8 8}$ & 532721,5 & 242669,4 & 387695,5 & 56,06 \\
$\mathbf{3 3 6}$ & 650319,9 & 290802,0 & 470561,0 & 72,04 \\
$\mathbf{4 0 8}$ & 636245,8 & 278207,8 & 457226,8 & 69,47 \\
\hline
\end{tabular}


APÊNDICE 4 - Tempo de experimento e consumo de ácido acético nos reatores anaeróbios em batelada

\begin{tabular}{|c|c|c|c|c|c|}
\hline \multicolumn{6}{|c|}{ Ensaio 1 - Ácido acético $(10 \mathrm{mmol} / \mathrm{L})$ e biomassa inicial $(0,02 \mathrm{~g} / \mathrm{L})$} \\
\hline \multirow[b]{2}{*}{ Tempo (h) } & \multicolumn{4}{|c|}{ Ácido acético (mmol/L) } & \multirow{2}{*}{$\begin{array}{c}\text { Consumo médio de } \\
\text { ácido acético } \\
(\%)\end{array}$} \\
\hline & reator 1 & reator 2 & reator 3 & média & \\
\hline $\mathbf{0}$ & 9,41 & 11,36 & 9,48 & 10,08 & 0 \\
\hline 24 & 9,25 & 9,53 & 9,78 & 9,52 & 6 \\
\hline 48 & 9,75 & 8,25 & 9,62 & 9,21 & 9 \\
\hline 72 & 8,96 & 7,76 & 8,51 & 8,41 & 17 \\
\hline 96 & 9,02 & 7,34 & 7,85 & 8,07 & 20 \\
\hline 120 & 7,41 & 7,03 & 6,90 & 7,11 & 29 \\
\hline 144 & 6,79 & 5,86 & 6,30 & 6,32 & 37 \\
\hline 168 & 6,28 & 5,35 & 5,52 & 5,72 & 43 \\
\hline 192 & 4,78 & 3,44 & 4,56 & 4,26 & 58 \\
\hline 216 & 4,73 & 2,76 & 4,68 & 4,06 & 60 \\
\hline 240 & 3,82 & 2,78 & 3,97 & 3,52 & 65 \\
\hline 288 & 3,40 & 2,39 & 3,62 & 3,14 & 69 \\
\hline 360 & 2,74 & 1,32 & 3,28 & 2,45 & 76 \\
\hline 384 & 1,78 & 2,14 & 2,74 & 2,22 & 78 \\
\hline 408 & 3,65 & 2,32 & 3,10 & 3,02 & 70 \\
\hline
\end{tabular}

Ensaio 2 - Ácido acético (17 mmol/L) e biomassa inicial $(0,02 \mathrm{~g} / \mathrm{L})$ Ácido acético (mmol/L)

Consumo médio de ácido acético

\begin{tabular}{cccccc} 
Tempo (h) & reator $\mathbf{1}$ & reator $\mathbf{2}$ & reator $\mathbf{3}$ & média & (\%) \\
\hline $\mathbf{0}$ & 17,35 & 19,07 & 15,29 & 17,23 & 0 \\
$\mathbf{2 4}$ & 17,31 & 17,00 & 16,34 & 16,88 & 2 \\
$\mathbf{4 8}$ & 15,40 & 16,41 & 18,78 & 16,86 & 2 \\
$\mathbf{7 2}$ & 14,27 & 15,50 & 16,25 & 15,34 & 11 \\
$\mathbf{9 6}$ & 15,59 & 15,11 & 15,51 & 15,40 & 11 \\
$\mathbf{1 2 0}$ & 16,65 & 14,78 & 15,28 & 15,57 & 10 \\
$\mathbf{1 4 4}$ & 14,54 & 14,20 & 13,54 & 14,09 & 18 \\
$\mathbf{1 6 8}$ & 11,94 & 13,46 & 13,78 & 13,06 & 24 \\
$\mathbf{1 9 2}$ & 10,07 & 12,04 & 9,42 & 10,51 & 39 \\
$\mathbf{2 1 6}$ & 8,18 & 11,29 & 10,20 & 9,89 & 43 \\
$\mathbf{2 4 0}$ & 8,51 & 9,58 & 9,29 & 9,12 & 47 \\
$\mathbf{2 8 8}$ & 10,06 & 9,96 & 9,23 & 9,75 & 43 \\
$\mathbf{3 6 0}$ & 10,81 & 10,00 & 9,50 & 10,11 & 41 \\
$\mathbf{3 8 4}$ & 7,80 & 9,23 & 8,26 & 8,43 & 51 \\
$\mathbf{4 0 8}$ & 8,03 & 9,21 & 12,16 & 9,80 & 43 \\
\hline
\end{tabular}




\begin{tabular}{cccccc}
\hline \multicolumn{5}{c}{ Ensaio 3 - Ácido acético (18 mmol/L) e biomassa inicial $\mathbf{( 0 , 0 4} \mathbf{~ g / L )}$} \\
\hline \multicolumn{5}{c}{ Ácido acético $\mathbf{( m m o l} / \mathbf{L})$} & $\begin{array}{c}\text { Consumo médio de } \\
\text { ácido acético }\end{array}$ \\
Tempo (h) & reator $\mathbf{1}$ & reator $\mathbf{2}$ & reator 3 & média & $(\%)$ \\
\hline $\mathbf{0}$ & 18,13 & 19,04 & 16,50 & 17,89 & 0 \\
$\mathbf{2 4}$ & 17,51 & 15,61 & 15,77 & 16,30 & 9 \\
$\mathbf{4 8}$ & 16,63 & 15,48 & 15,56 & 15,89 & 11 \\
$\mathbf{7 2}$ & 15,29 & 17,19 & 14,51 & 15,66 & 12 \\
$\mathbf{9 6}$ & 14,27 & 12,77 & 17,32 & 14,78 & 17 \\
$\mathbf{1 9 2}$ & 11,24 & 12,99 & 16,60 & 13,61 & 24 \\
$\mathbf{2 4 0}$ & 14,01 & 14,95 & 15,41 & 14,79 & 17 \\
$\mathbf{2 6 4}$ & 15,57 & 14,57 & 14,53 & 14,89 & 17 \\
$\mathbf{2 8 8}$ & 14,99 & 13,70 & 15,20 & 14,63 & 18 \\
$\mathbf{3 6 0}$ & 9,18 & 5,53 & 6,56 & 7,09 & 60 \\
$\mathbf{3 8 4}$ & 6,08 & 5,45 & 5,19 & 5,57 & 69 \\
$\mathbf{4 0 8}$ & 5,44 & 5,20 & 5,54 & 5,39 & 70 \\
\hline
\end{tabular}

Ensaio 4 - Ácido acético (22 mmol/L) e biomassa inicial (0,04 g/L) Ácido acético $(\mathrm{mmol} / \mathrm{L})$

Consumo médio de

\begin{tabular}{ccccc} 
Tempo $(\mathbf{h})$ & reator $\mathbf{1}$ & reator 2 & média & $\begin{array}{c}\text { ácido acético } \\
(\mathbf{\%})\end{array}$ \\
\hline $\mathbf{0}$ & 22,96 & 20,55 & 21,75 & 0 \\
$\mathbf{2 4}$ & 22,02 & 21,39 & 21,70 & 0 \\
$\mathbf{4 8}$ & 21,92 & 20,44 & 21,18 & 3 \\
$\mathbf{7 2}$ & 19,67 & 20,13 & 19,90 & 9 \\
$\mathbf{9 6}$ & 17,13 & 17,04 & 17,09 & 21 \\
$\mathbf{1 2 0}$ & 22,81 & 18,01 & 20,41 & 6 \\
$\mathbf{1 4 4}$ & 24,71 & 13,41 & 19,06 & 12 \\
$\mathbf{1 6 8}$ & 17,61 & 20,07 & 18,84 & 13 \\
$\mathbf{1 9 2}$ & 20,47 & 14,04 & 17,25 & 21 \\
$\mathbf{2 1 6}$ & 10,08 & 10,08 & 10,08 & 54 \\
$\mathbf{2 4 0}$ & 10,10 & 10,45 & 10,27 & 53 \\
$\mathbf{2 6 4}$ & 10,46 & 8,64 & 9,55 & 56 \\
$\mathbf{2 8 8}$ & 9,03 & 9,62 & 9,33 & 57 \\
$\mathbf{3 3 6}$ & 9,41 & 9,52 & 9,47 & 56 \\
$\mathbf{4 0 8}$ & 9,82 & 9,95 & 9,88 & 55 \\
\hline
\end{tabular}




\begin{tabular}{|c|c|c|c|c|c|}
\hline \multicolumn{6}{|c|}{ Ensaio 5 - Ácido acético (22 mmol/L) e biomassa inicial $(0,04 \mathrm{~g} / \mathrm{L})$} \\
\hline \multirow[b]{2}{*}{ Tempo (h) } & \multicolumn{4}{|c|}{ Ácido acético $(\mathrm{mmol} / \mathrm{L})$} & \multirow{2}{*}{$\begin{array}{c}\text { Consumo médio de } \\
\text { ácido acético } \\
(\%)\end{array}$} \\
\hline & reator 1 & reator 2 & reator 3 & média & \\
\hline $\mathbf{0}$ & 20,92 & 22,19 & 22,43 & 21,85 & 0 \\
\hline 24 & 21,96 & 21,98 & 22,41 & 22,12 & 8 \\
\hline 48 & 21,87 & 21,43 & 17,16 & 20,15 & 0 \\
\hline 72 & 26,25 & 20,15 & 19,70 & 22,03 & 9 \\
\hline 96 & 20,11 & 20,22 & 19,17 & 19,83 & 5 \\
\hline 120 & 18,61 & 25,52 & 18,14 & 20,75 & 0 \\
\hline 192 & 29,30 & 23,48 & 20,32 & 24,36 & 0 \\
\hline 216 & 24,46 & 23,84 & 20,45 & 22,92 & 0 \\
\hline 240 & 27,35 & 20,65 & 21,96 & 23,32 & 5 \\
\hline 288 & 23,31 & 18,65 & 20,14 & 20,70 & 0 \\
\hline 336 & 23,08 & 21,34 & 21,11 & 21,85 & 0 \\
\hline 408 & 21,39 & 22,95 & 23,83 & 22,72 & 0 \\
\hline
\end{tabular}


APÊNDICE 5 - Determinação da velocidade específica de crescimento e tempo de geração

Ensaio 1 - Ácido acético (10 mmol/L) e biomassa inicial (0,02 g/L)

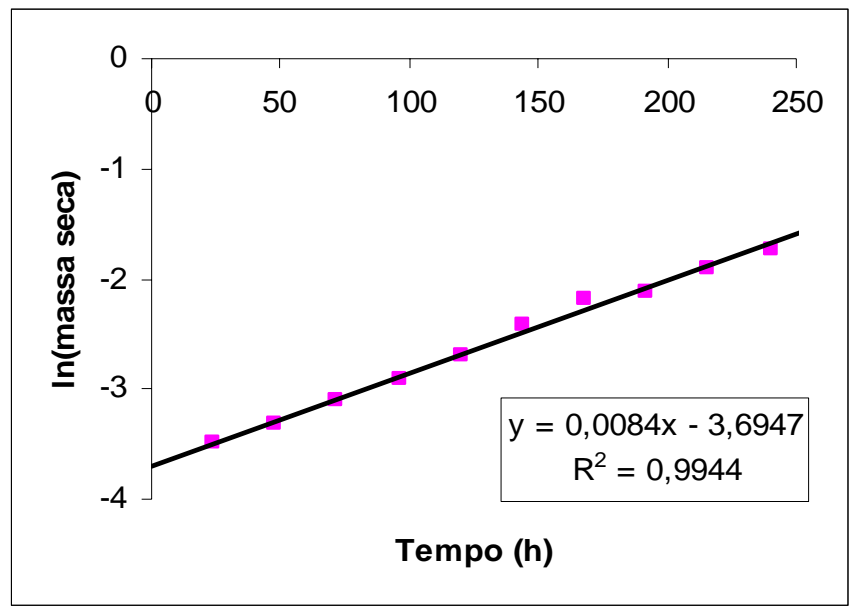

Ensaio 2 - Ácido acético (17 mmol/L) e biomassa inicial (0,02 g/L)

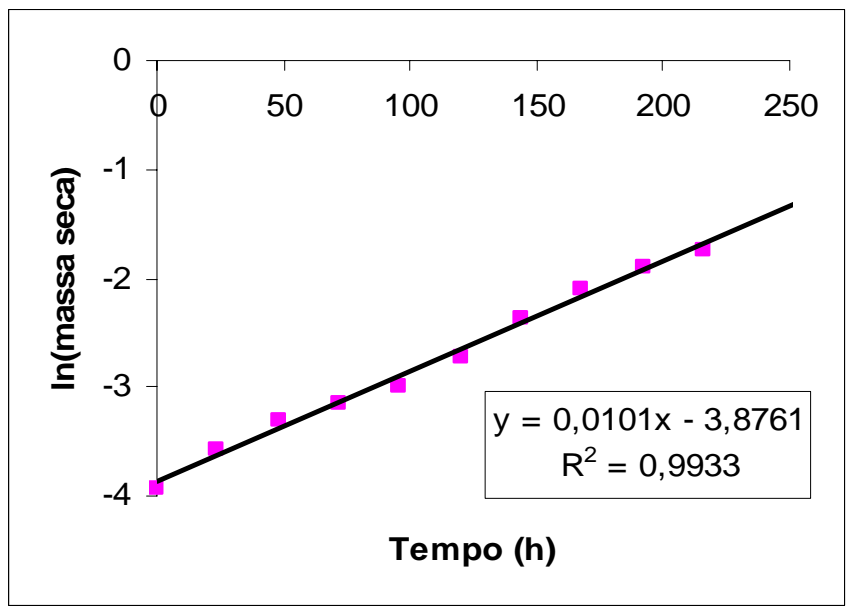


Ensaio 3 - Ácido acético (18 mmol/L) e biomassa inicial (0,04 g/L)

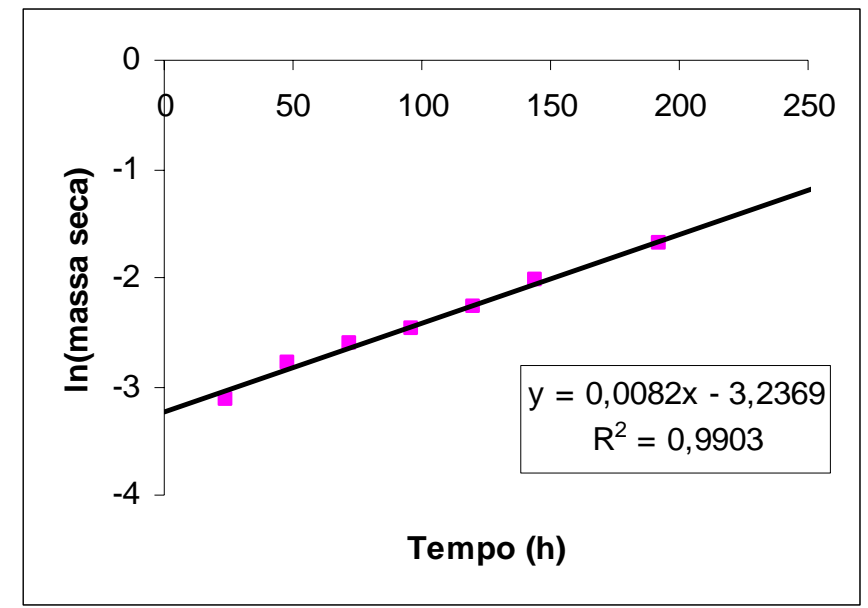

Ensaio 4 - Ácido acético (22 mmol/L) e biomassa inicial (0,04 g/L)

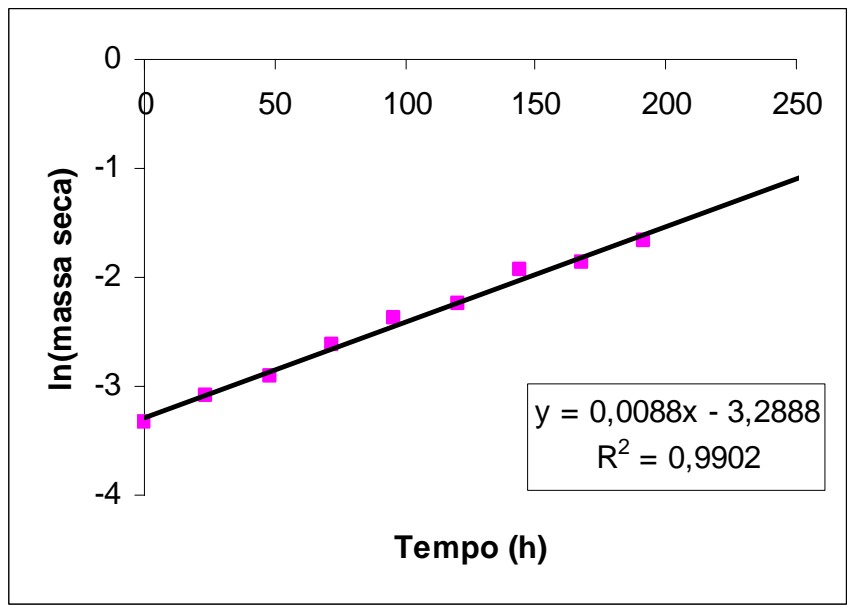


APÊNDICE 6 - Determinação da velocidade máxima de produção de hidrogênio nos reatores anaeróbios em batelada

Ensaio 1 - Ácido acético (10 mmol/L) e biomassa inicial (0,02 g/L)

\begin{tabular}{cc}
\hline Tempo $(\mathbf{h})$ & $\begin{array}{r}\text { Velocidade de produção de hidrogênio } \\
\text { (mL } \mathbf{H}_{\mathbf{2}} / \mathbf{g} \text { massa seca.h) }\end{array}$ \\
\hline 0 & 0,09425 \\
6,5 & 0,11759 \\
13,0 & 0,17569 \\
19,5 & 0,26203 \\
26,0 & 0,38972 \\
32,5 & 0,57731 \\
39,1 & 0,85011 \\
45,6 & 1,24091 \\
52,1 & 1,78849 \\
58,6 & 2,53121 \\
65,1 & 3,49205 \\
71,6 & 4,65277 \\
78,1 & 5,92208 \\
84,6 & 7,11748 \\
91,1 & 7,99209 \\
97,6 & 8,32126 \\
104,1 & 8,01112 \\
110,6 & 7,15025 \\
117,2 & 5,96083 \\
123,7 & 4,69062 \\
130,2 & 3,52478 \\
136,7 & 2,55728 \\
143,2 & 1,80811 \\
149,7 & 1,25511 \\
156,2 & 0,86011 \\
162,7 & 0,58423 \\
169,2 & 0,39445 \\
175,7 & 0,26523 \\
182,2 & 0,17786 \\
188,7 & 0,11904 \\
195,3 & 0,07958 \\
201,8 & 0,05316 \\
208,3 & 0,03549 \\
214,8 & 0,02368 \\
221,3 & 0,01580 \\
227,8 & 0,01054 \\
234,3 & 0,00703 \\
240,8 & 0,00469 \\
247,3 & 0,00313 \\
253,8 & 0,00209 \\
260,3 & 0,00139 \\
266,8 & 0,00093 \\
273,4 & \\
& \\
\hline &
\end{tabular}




\begin{tabular}{lc}
\hline 279,9 & 0,00041 \\
286,4 & 0,00027 \\
292,9 & 0,00018 \\
299,4 & 0,00012 \\
305,9 & 0,00008 \\
312,4 & 0,00005 \\
318,9 & 0,00004 \\
325,4 & 0,00002 \\
331,9 & 0,00002 \\
338,4 & 0,00001 \\
344,9 & 0,00001 \\
351,5 & 0 \\
358,0 & 0 \\
364,5 & 0 \\
371,0 & 0 \\
377,5 & 0 \\
384,0 & 0 \\
\hline
\end{tabular}

Máxima velocidade de produção de hidrogênio

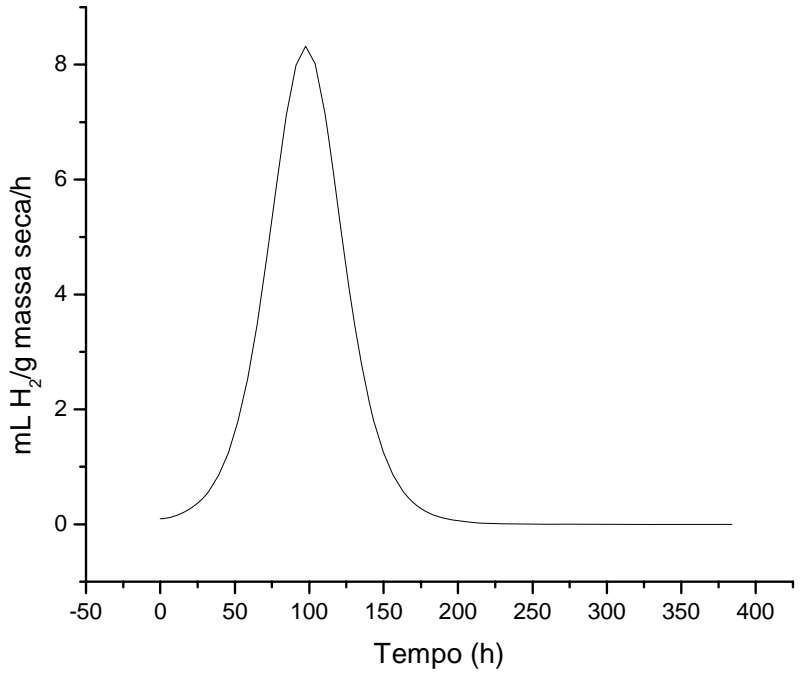


Ensaio 2 - Ácido acético (17 mmol/L) e biomassa inicial (0,02 g/L)

\begin{tabular}{|c|c|}
\hline Tempo (h) & $\begin{array}{c}\text { Velocidade de produção de hidrogênio } \\
\left(\mathrm{mL} \mathrm{H}_{2} / \mathrm{g} \text { massa seca.h) }\right.\end{array}$ \\
\hline 0 & 0,00490 \\
\hline 6,9 & 0,00684 \\
\hline 13,8 & 0,01225 \\
\hline 20,7 & 0,02195 \\
\hline 27,7 & 0,03931 \\
\hline 34,6 & 0,07033 \\
\hline 41,5 & 0,12566 \\
\hline 48,4 & 0,22390 \\
\hline 55,3 & 0,39706 \\
\hline 62,2 & 0,69823 \\
\hline 69,2 & 1,20987 \\
\hline 76,1 & 2,04422 \\
\hline 83,0 & 3,31265 \\
\hline 89,9 & 5,02651 \\
\hline 96,8 & 6,92913 \\
\hline 103,7 & 8,41448 \\
\hline 110,6 & 8,80375 \\
\hline 117,6 & 7,89192 \\
\hline 124,5 & 6,14193 \\
\hline 131,4 & 4,26341 \\
\hline 138,3 & 2,72423 \\
\hline 145,2 & 1,64788 \\
\hline 152,1 & 0,96349 \\
\hline 159,1 & 0,55208 \\
\hline 166,0 & 0,31266 \\
\hline 172,9 & 0,17590 \\
\hline 179,8 & 0,09859 \\
\hline 186,7 & 0,05514 \\
\hline 193,6 & 0,03080 \\
\hline 200,5 & 0,01720 \\
\hline 207,5 & 0,00960 \\
\hline 214,4 & 0,00535 \\
\hline 221,3 & 0,00299 \\
\hline 228,2 & 0,00167 \\
\hline 235,1 & 0,00093 \\
\hline 242,0 & 0,00052 \\
\hline 248,9 & 0,00029 \\
\hline 255,9 & 0,00016 \\
\hline 262,8 & 0,00009 \\
\hline 269,7 & 0,00005 \\
\hline 276,6 & 0,00003 \\
\hline 283,5 & 0,00002 \\
\hline 290,4 & 0,00001 \\
\hline 297,4 & 0 \\
\hline 304,3 & 0 \\
\hline 311,2 & 0 \\
\hline 318,1 & 0 \\
\hline
\end{tabular}




\begin{tabular}{ll}
\hline 325,0 & 0 \\
331,9 & 0 \\
338,8 & 0 \\
345,8 & 0 \\
352,7 & 0 \\
359,6 & 0 \\
366,5 & 0 \\
373,4 & 0 \\
380,3 & 0 \\
387,3 & 0 \\
394,2 & 0 \\
401,1 & 0 \\
408,0 & 0 \\
\hline
\end{tabular}

Máxima velocidade de produção de hidrogênio

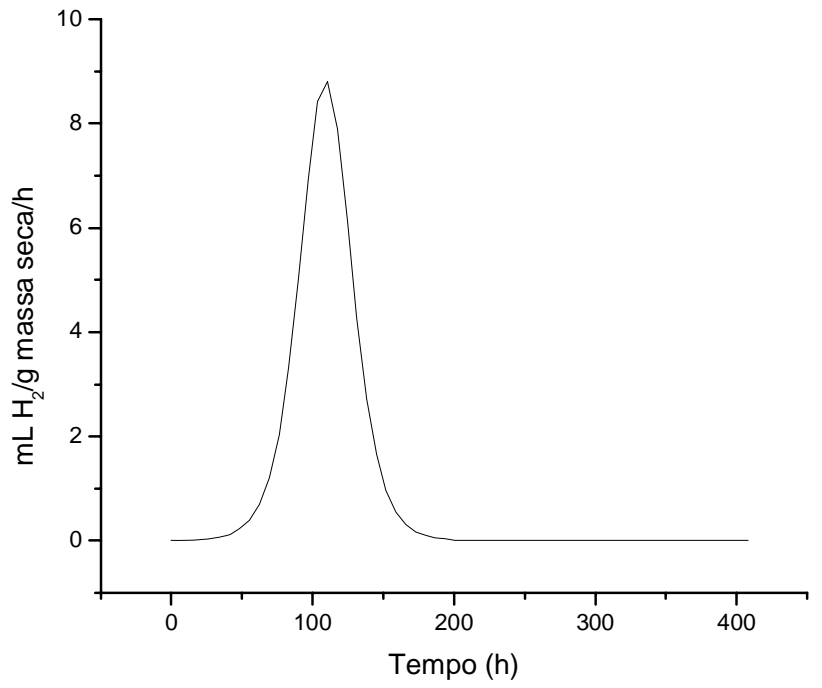


Ensaio 3 - Ácido acético (18 mmol/L) e biomassa inicial (0,04 g/L)

\begin{tabular}{|c|c|}
\hline Tempo (h) & $\begin{array}{l}\text { Velocidade de produção de hidrogênio } \\
\left(\mathrm{mL} \mathrm{H}_{2} / \mathrm{g} \text { massa seca.h) }\right.\end{array}$ \\
\hline 0 & 0,05688 \\
\hline 6,1 & 0,08023 \\
\hline 12,2 & 0,14594 \\
\hline 18,3 & 0,26472 \\
\hline 24,4 & 0,47781 \\
\hline 30,5 & 0,85478 \\
\hline 36,6 & 1,50516 \\
\hline 42,7 & 2,57854 \\
\hline 48,8 & 4,21851 \\
\hline 54,9 & 6,41604 \\
\hline 61,0 & 8,77480 \\
\hline 67,1 & 10,44548 \\
\hline 73,2 & 10,59556 \\
\hline 79,3 & 9,14169 \\
\hline 85,4 & 6,83237 \\
\hline 91,5 & 4,56438 \\
\hline 97,6 & 2,81937 \\
\hline 103,7 & 1,65635 \\
\hline 109,8 & 0,94419 \\
\hline 115,9 & 0,52892 \\
\hline 122,0 & 0,29339 \\
\hline 128,1 & 0,16185 \\
\hline 134,2 & 0,08901 \\
\hline 140,3 & 0,04887 \\
\hline 146,4 & 0,02681 \\
\hline 152,5 & 0,01470 \\
\hline 158,6 & 0,00806 \\
\hline 164,7 & 0,00442 \\
\hline 170,8 & 0,00242 \\
\hline 176,9 & 0,00133 \\
\hline 183,1 & 0,00073 \\
\hline 189,2 & 0,00040 \\
\hline 195,3 & 0,00022 \\
\hline 201,4 & 0,00012 \\
\hline 207,5 & 0,00007 \\
\hline 213,6 & 0,00004 \\
\hline 219,7 & 0,00002 \\
\hline 225,8 & 0,00001 \\
\hline 231,9 & 0,00001 \\
\hline 238,0 & 0 \\
\hline 244,1 & 0 \\
\hline 250,2 & 0 \\
\hline 256,3 & 0 \\
\hline 262,4 & 0 \\
\hline 268,5 & 0 \\
\hline 274,6 & 0 \\
\hline 280,7 & 0 \\
\hline
\end{tabular}




\begin{tabular}{ll}
\hline 286,8 & 0 \\
292,9 & 0 \\
299,0 & 0 \\
305,1 & 0 \\
311,2 & 0 \\
317,3 & 0 \\
323,4 & 0 \\
329,5 & 0 \\
335,6 & 0 \\
341,7 & 0 \\
347,8 & 0 \\
353,9 & 0 \\
360,0 & 0 \\
\hline
\end{tabular}

Máxima velocidade de produção de hidrogênio

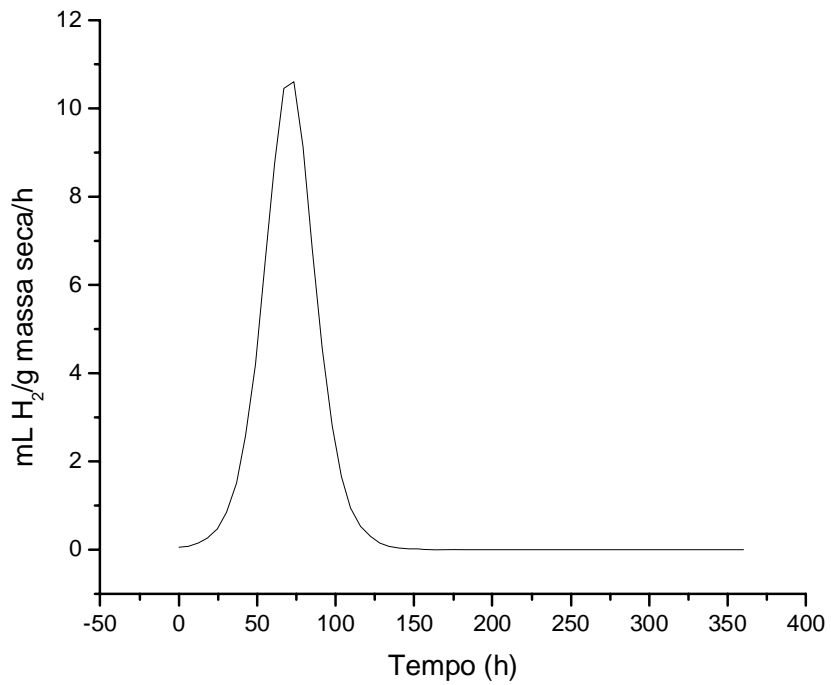


Ensaio 4 - Ácido acético (22 mmol/L) e biomassa inicial (0,04 g/L)

\begin{tabular}{cc}
\hline Tempo (h) & mL $\mathbf{H}_{2} / \mathbf{g}$ massa seca \\
\hline $\mathbf{0}$ & 0 \\
$\mathbf{2 4}$ & 0 \\
$\mathbf{4 8}$ & 0 \\
$\mathbf{7 2}$ & 21,67 \\
$\mathbf{9 6}$ & 125,78 \\
$\mathbf{1 2 0}$ & 142,05 \\
$\mathbf{1 4 4}$ & 157,35 \\
$\mathbf{1 6 8}$ & 143,83 \\
$\mathbf{1 9 2}$ & 172,79 \\
$\mathbf{2 1 6}$ & 192,47 \\
$\mathbf{2 4 0}$ & 230,96 \\
$\mathbf{2 6 4}$ & 260,03 \\
$\mathbf{2 8 8}$ & 283,11 \\
\hline
\end{tabular}

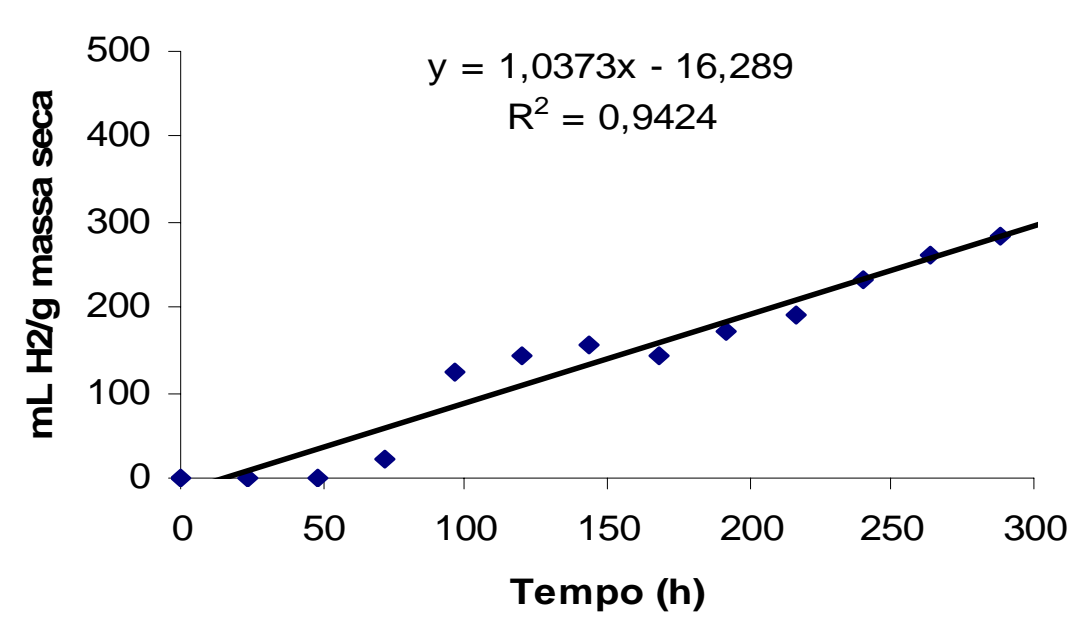


APÊNDICE 7 - Valores de massa seca e produção de hidrogênio do ensaio de caracterização nutricional

\begin{tabular}{|c|c|c|c|c|c|c|c|c|}
\hline \multirow{3}{*}{$\begin{array}{c}\text { Substratos } \\
\text { orgânicos } \\
(20 \mathrm{mmol} / \mathrm{L})\end{array}$} & \multicolumn{8}{|c|}{ Massa seca $(\mathrm{g} / \mathrm{L})$} \\
\hline & \multicolumn{4}{|c|}{$\mathbf{O} \mathbf{h}$} & \multicolumn{4}{|c|}{$384 \mathrm{~h}$} \\
\hline & $\begin{array}{c}\text { reator } \\
1\end{array}$ & $\begin{array}{l}\text { reator } \\
2\end{array}$ & $\begin{array}{c}\text { reator } \\
3\end{array}$ & média & $\begin{array}{c}\text { reator } \\
1\end{array}$ & $\begin{array}{c}\text { reator } \\
2\end{array}$ & $\begin{array}{c}\text { reator } \\
3\end{array}$ & média \\
\hline $\begin{array}{l}\text { acetato de } \\
\text { sódio }\end{array}$ & 0,020 & 0,021 & 0,019 & 0,020 & 0,321 & 0,222 & 0,208 & 0,250 \\
\hline $\begin{array}{c}\text { benzoato de } \\
\text { sódio }\end{array}$ & 0.020 & 0.020 & 0.021 & 0.020 & 0.030 & 0.058 & 0.068 & 0.052 \\
\hline butirato de & & & & & & & & \\
\hline $\begin{array}{c}\text { sódio } \\
\text { citrato de }\end{array}$ & 0,020 & 0,020 & 0,018 & 0,020 & 0,121 & 0,090 & 0,129 & 0,114 \\
\hline sódio & 0,023 & 0,021 & 0,022 & 0,022 & 0,292 & 0,315 & 0,205 & 0,271 \\
\hline etanol & 0,020 & 0,018 & 0,022 & 0,020 & 0,000 & 0,075 & 0,095 & 0,085 \\
\hline fenol & 0,026 & 0,024 & 0,024 & 0,025 & 0,027 & 0,026 & 0,000 & 0,027 \\
\hline frutose & 0,028 & 0,026 & 0,025 & 0,026 & 0,079 & 0,087 & 0,060 & 0,075 \\
\hline glicose & 0,026 & 0,024 & 0,024 & 0,025 & 0,088 & 0,071 & 0,108 & 0,089 \\
\hline $\begin{array}{l}\text { glutamato de } \\
\text { sódio }\end{array}$ & 0,024 & 0,020 & 0,022 & 0,022 & 0,034 & 0,025 & 0,042 & 0,034 \\
\hline $\begin{array}{l}\text { lactato de } \\
\text { sódio }\end{array}$ & 0,018 & 0,020 & 0,020 & 0,020 & 0,026 & 0,015 & 0,012 & 0,017 \\
\hline metanol & 0,023 & 0,021 & 0,016 & 0,020 & 0,079 & 0,076 & 0,090 & 0,082 \\
\hline $\begin{array}{l}\text { piruvato de } \\
\text { sódio } \\
\text { pronionato }\end{array}$ & 0,022 & 0,021 & 0,024 & 0,022 & 0,184 & 0,149 & 0,106 & 0,146 \\
\hline de sódio & 0,022 & 0,024 & 0,019 & 0,022 & 0,183 & 0,209 & 0,177 & 0,189 \\
\hline $\begin{array}{l}\text { succinato de } \\
\text { sódio }\end{array}$ & 0,027 & 0,024 & 0,023 & 0,025 & 0,112 & 0,176 & 0,195 & 0,161 \\
\hline
\end{tabular}




\begin{tabular}{|c|c|c|c|c|c|}
\hline \multirow{2}{*}{$\begin{array}{c}\text { Substratos } \\
\text { orgânicos } \\
(20 \mathrm{mmol} / \mathrm{L}) \\
\end{array}$} & \multicolumn{4}{|c|}{ Área cromatográfica do hidrogênio } & \multirow{2}{*}{$\begin{array}{c}\text { Produção média de } \mathrm{H}_{2} \\
\text { no headspace } \\
(\mathrm{mL})\end{array}$} \\
\hline & reator 1 & reator 2 & reator 3 & média & \\
\hline acetato de sódio & 465514,3 & 433042,5 & - & 449278,4 & 3,40 \\
\hline $\begin{array}{l}\text { benzoato ae } \\
\text { sódio } \\
\text { butirato de }\end{array}$ & 1043,9 & - & 2485,9 & 1764,9 & 0,00 \\
\hline sódio & 57311,2 & 44629,6 & 60814,2 & 54251,7 & 0,00 \\
\hline citrato de sódio & 554296,6 & 404632,0 & - & 479464,3 & 3,69 \\
\hline etanol & - & 1256,8 & - & 1256,8 & 0,00 \\
\hline fenol & - & 1734,3 & - & 1734,3 & 0,00 \\
\hline frutose & 331096,5 & 224013,2 & 285084,1 & 280064,6 & 1,76 \\
\hline $\begin{array}{c}\text { glicose } \\
\text { glutamato de }\end{array}$ & 174453,1 & 325373,8 & 433815,6 & 311214,2 & 2,06 \\
\hline sódio & 0,0 & 0,0 & 0,0 & 0,0 & 0,00 \\
\hline lactato de sódio & 8390,2 & - & - & 8390,2 & 0,00 \\
\hline $\begin{array}{c}\text { metanol } \\
\text { piruvato de }\end{array}$ & 0,0 & 0,0 & 0,0 & 0,0 & 0,00 \\
\hline $\begin{array}{c}\text { sódio } \\
\text { propionato de }\end{array}$ & 534549,2 & 292578,3 & 210112,7 & 345746,7 & 2,40 \\
\hline $\begin{array}{c}\text { sódio } \\
\text { succinato de }\end{array}$ & 312665,6 & 483946,7 & 365208,2 & 387273,5 & 2,80 \\
\hline sódio & - & 429339,1 & 105002,4 & 267170,8 & 1,64 \\
\hline
\end{tabular}


ANEXO 1 - Curva de calibração do hidrogênio

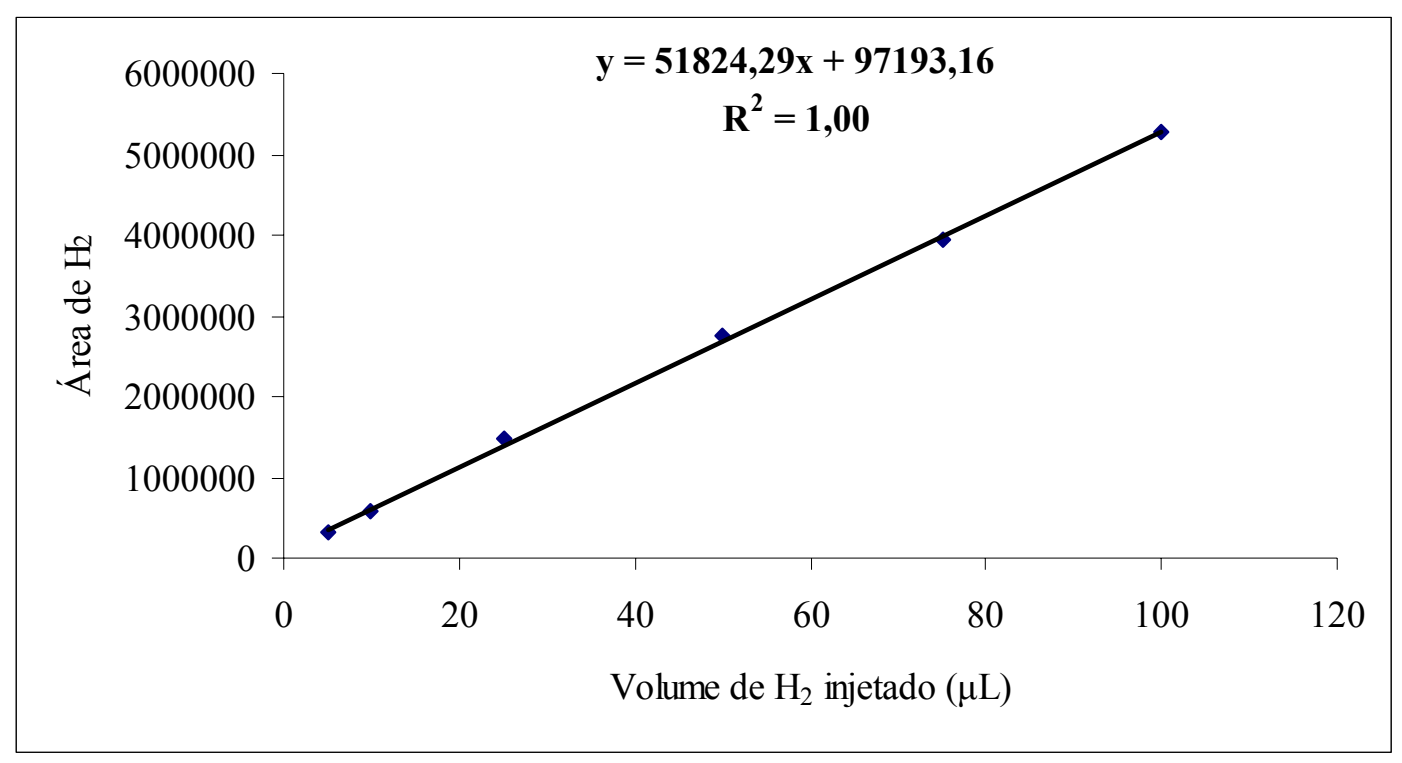

